\title{
ETNOCONHECIMENTO CAIÇARA E USO DE RECURSOS PESQUEIROS POR PESCADORES ARTESANAIS E ESPORTIVOS NO VALE DO RIBEIRA
}

\author{
MILENA RAMIRES DE SOUZA
}

Dissertação apresentada à Escola Superior de Agricultura "Luiz de Queiroz", Universidade de São Paulo, para obtenção do título de Mestre em Ecologia de Agroecossistemas.

P I R A C I C A B A

Estado de São Paulo - Brasil

Maio - 2004 


\title{
ETNOCONHECIMENTO CAIÇARA E USO DE RECURSOS PESQUEIROS POR PESCADORES ARTESANAIS E ESPORTIVOS NO VALE DO RIBEIRA
}

\author{
MILENA RAMIRES DE SOUZA \\ Bióloga
}

Orientadora: $\operatorname{Prof}^{\mathrm{a}}{ }^{.} \mathrm{Dr}^{\mathrm{a}}$. SILVIA MARIA GUERRA MOLINA

Dissertação apresentada à Escola Superior de Agricultura "Luiz de Queiroz", Universidade de São Paulo, para obtenção do título de Mestre em Ecologia de Agroecossistemas.

P I R A C I C A B A

Estado de São Paulo - Brasil

Maio - 2004 


\section{Dados Internacionais de Catalogação na Publicação (CIP) DIVSÃO DE BIBLIOTECA E DOCUMENTAC̄̃OO - ESALQ/USP}

\section{Souza, Milena Ramires de}

Etnoconhecimento caiçara e uso de recursos pesqueiros por pescadores artesanais e esportivos no Vale do Ribeira / Milena Ramires de Souza. - -

Piracicaba, 2004.

102 p. : il.

Dissertação (mestrado) - - Escola Superior de Agricultura Luiz de Queiroz, 2004.

Bibliografia.

1. Caiçara 2. Ecologia humana 3. Etnobiologia 4. Pesca artesanal 5. Pesca esportivé 6. Pescadores 7. Recursos pesqueiros I. Título

CDD 333.956

"Permitida a cópia total ou parcial deste documento, desde que citada a fonte - O autor" 


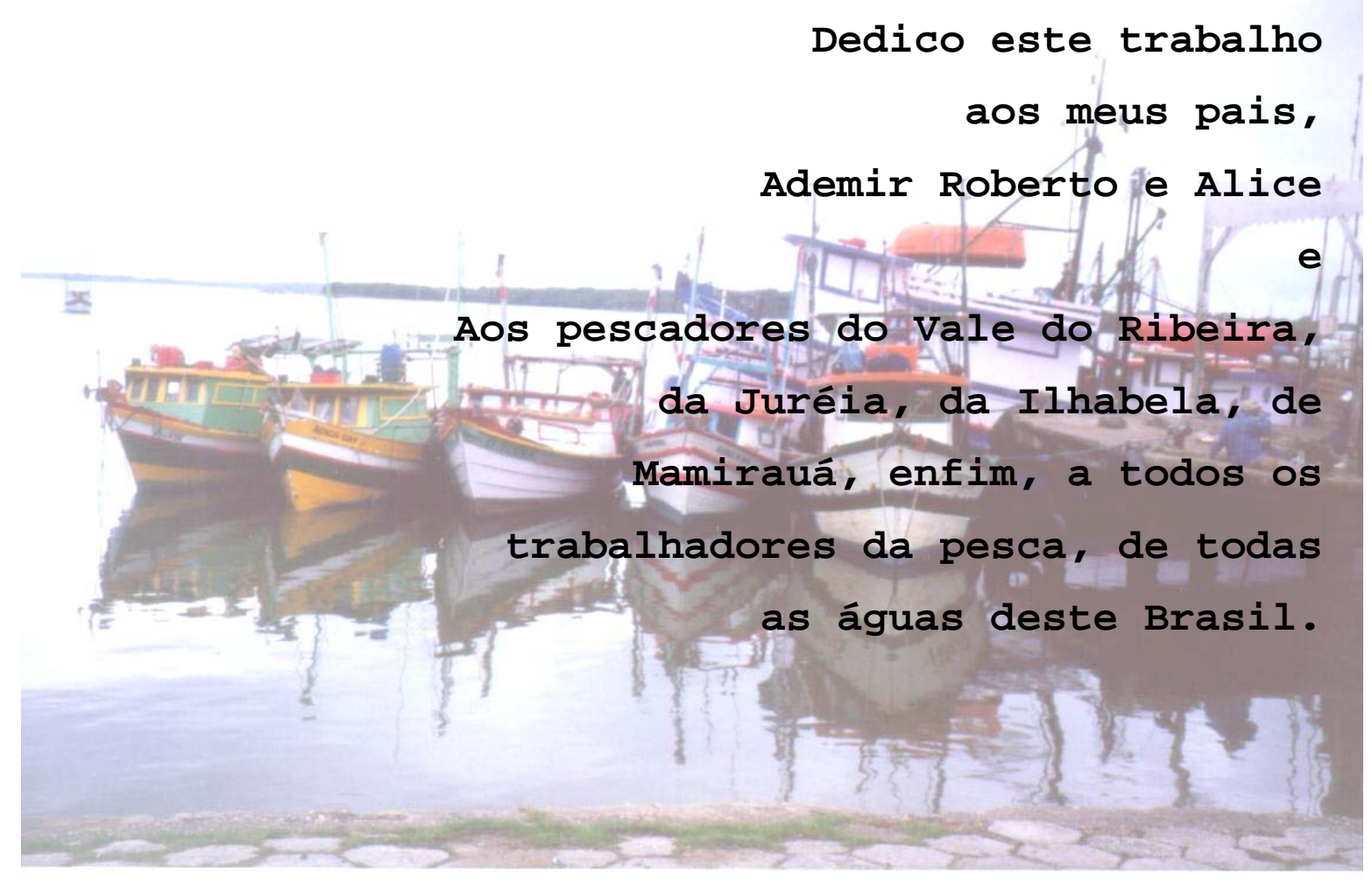




\section{O MAR E SEUS PESCADORES}

Que dele cuidam

$\mathrm{E}$ que por ele são nutridos

Sua sabedoria ancestral

Passadas

De pai e mãe

Para filhos e filhas

Suas riquezas, suas belezas

Suas vidas, suas alegrias,

suas mortes

Robalo, Cação, Pescada,

Manjuba, Tainha, Parati

Esses e outros tantos nomes

Tantos nomes

Tantos usos

Tantas cores e formas

Tantos ciclos

Tantos modos

Tantos significados

Vivo do mar e pelo mar

Esse mar

o meu ...

o nosso mar.

\section{DEMIS LIMA}

(poeta, biólogo,

grande amigo

e "amante do mar")
- caiçara vai a pesca Antes do raiar do dia Desafia na canoa

As sombras da maresia

É madrugada ainda

E lá se vai o pescador $\mathrm{Na}$ enseada ou na restinga Um solitário remador Leva a rede, o espinhel, o caniço e o samburá. Sobre as ondas, debaixo do céu Lá vai ele a remar (...)

(Carrigo e Relen Salubergth)

Sr. João

(pescador da Barra do Una/ Juréia)

\section{VIDA CAIÇARA}

A vida de pescador Nessa lida com o mar Mistura o prazer e a dor Alegria e penar

É um estranho caso de amor Que nunca vai terminar Mesmo que este madrugador Já não possa mais remar 


\section{AGRADECIMENTOS}

A autoria deste trabalho não seria possível sem a múltipla contribuição de pessoas que passaram por minha vida durante toda esta fase. Pessoas muito importantes e dedicadas, pessoas simples e companheiras, pessoas amigas e carinhosas. Dessa forma, meus sinceros agradecimentos vão à:

Profa. Dra. Silvia Maria Guerra Molina, primeiramente por ter acreditado no meu trabalho e aceitado participar da minha vida acadêmica, com a função primordial, que é a orientação. Também agradeço pela amizade, apoio, incentivo e principalmente pela confiança e pelos elogios.

Prof. Dr. Walter Barrella, pelo apoio, amizade, incentivo e principalmente por todas as portas gentilmente abertas e pelos caminhos apontados. Caminhos estes que direcionaram não só este trabalho, mas também minha vida acadêmica desde a graduação. Aos bons momentos junto à equipe do projeto, as bem humoradas viagens de campo. À oportunidade de "arrastar o chinelinho" pelas diversas praias do Vale do Ribeira. Pelos eventos, simpósios, encontros, publicações e pelo prazer de viver em meio aos pesquisadores, alunos e pescadores envolvidos ao projeto "Os Peixes e a Pesca" que resultou num lindo trabalho e a ele (o projeto) atribuo esta dissertação como uma "florzinha pretensiosa" que busca gerar muitos frutos.

Dra. Natalia Hanazaki, primeiramente pelas tentativas de orientação que não representaram apenas o interesse, mas principalmente confiança e entusiasmo. Por toda co-orientação, pelas leituras críticas desde a fase de projeto, pelas indicações, recomendações e palavras de incentivo. E principalmente por toda contribuição na fase final.

Dra. Alpina Begossi, pela oportunidade de crescer como pesquisadora através da participação em seus projetos. Pela amizade cultivada, confiança e principalmente co-orientação.

Profa. Dra. Maria Elisa Eduardo de Paula Garavello, pela força, incentivo e contribuições.

As amigas Mariana Clauzet, Priscila Lopes e Luziana Silva pela ajuda e companheirismo em trabalhos de campo, simpósios, encontros. Pelas dicas e leituras críticas. 
As amigas Gisele Bernardi e Luciana Bides, bem como todos os amigos de Sorocaba, que desde a graduação contribuíram com muita preocupação, incentivos e críticas.

À Cris, Ivete, Edson e João Victor, pelas "defesas incondicionais", fé, torcida e incentivo.

À Márcia, uma pessoa que se tornou tão amiga rapidamente pelas afinidades, identidade, condição e situação. Pelas contribuições, pelas discussões intelectualmente prazerosas. Pelo incentivo. Pela força nas horas mais difíceis. Pela companhia nos momentos de sofrimento em Piracicaba. Pelo ombro amigo e toda paciência da convivência.

Ao Anderson, por todo carinho e pela companhia alegre e prazerosa.

Aos amigos da Vila Estudantil, Maurício, Henrique, Fabiana, Ana Paula, Raquel, Kátia, Daruska, Julio, Juan, Wiri, Claudia, Milena Lisita, Analy, Miriam, Rô, que me receberam de braços abertos e compartilharam tristezas e alegrias da etapa final deste trabalho. Em especial ao Elio pela contribuição nas revisões e principalmente pela amizade e carinho.

Aos amigos do grupo de estudos do laboratório de ecologia humana da Esalq, em especial a Julia, pelas contribuições, discussões e amizade.

Ao amigo Alê, (Alessandro Archidiacono), por toda atenção, preocupação, companhia em eventos e principalmente pelos momentos de descontração.

As meninas do NUPAUB/USP (Iaskara, Márcia, Estela e Paulinha) e Prof. Diegues, principalmente pela adorável recepção no núcleo e principalmente nos encontros e apresentações.

Aos meus pais, por terem proporcionado o primeiro contato com a cultura e o ambiente caiçara, por todo amor, dedicação, compreensão e por todo suporte emotivo e financeiro. A toda minha família pela admiração, orgulho e incentivo, em especial a minha vó Encarnação.

Finalmente, a todos os pescadores e suas famílias, que de várias formas contribuíram e sem os quais este trabalho não teria a importância que tem (principalmente pessoal).

A todos vocês meu "MUITO OBRIGADA".

Milena Ramires 


\section{SUMÁRIO}

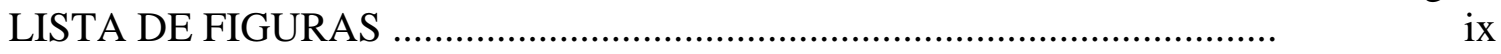

LISTA DE TABELAS................................................................................

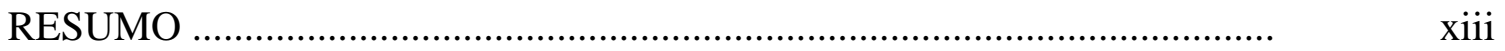

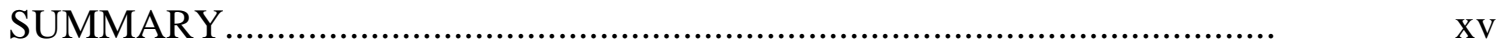

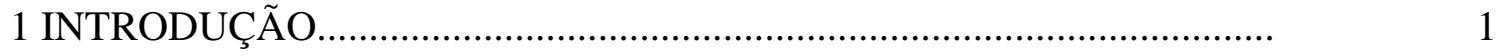

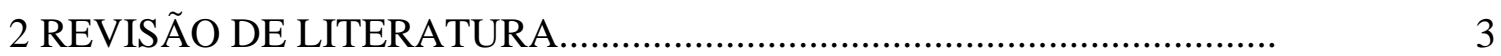

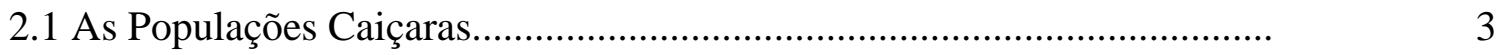

2.2 A Pesca Artesanal.....................................................................................

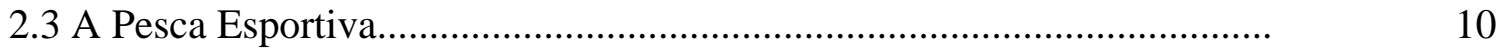

2.4 Interações entre as Populações Humanas e a Natureza................................. 13

2.1.1 Ecologia Humana....................................................................................

2.1.2 Etnobiologia e Etnoecologia.....................................................................

2.1.3 As Correntes de Pensamento da Etnobiologia e Etnoecologia ................ 18

2.1.4 Etnoictiologia........................................................................................ 20

2.1.5 Considerações sobre o Etnoconhecimento Caiçara.................................... 22

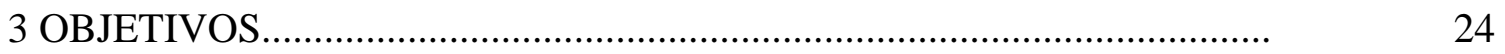

3.1 Objetivo geral....................................................................................

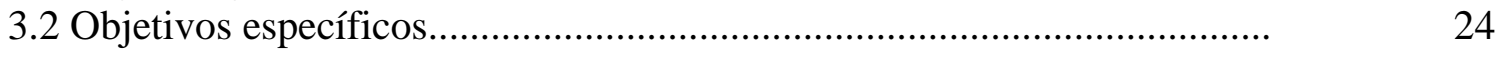

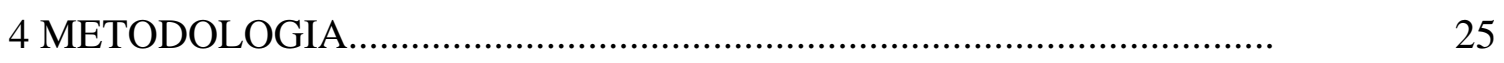

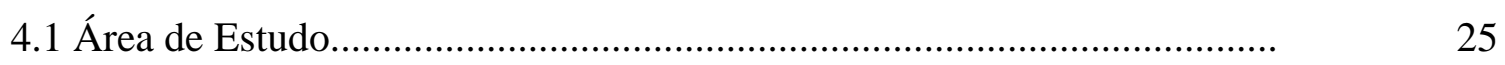

4.1.2 As Comunidades Caiçaras........................................................................ 25

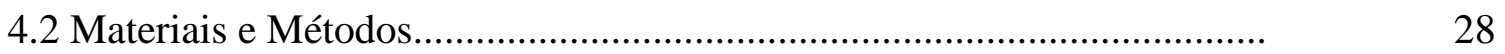

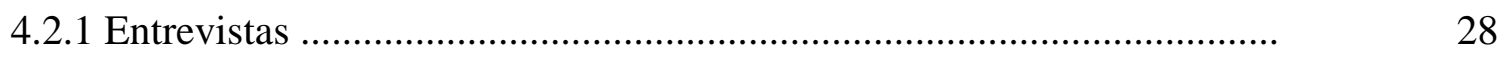

4.2.2 Coleta de Dados sobre a Pesca Artesanal.................................................. 28

4.2.3 Levantamento Etnoictiológico.................................................................... 29

4.2.4 Coleta de Dados sobre a Pesca Esportiva................................................... 29

4.2.5 Observações Diretas..............................................................................

4.2.6 Coleta de Material Biológico..................................................................... 30 
5 RESULTADOS E DISCUSSÃO......................................................

5.1 Pesca Artesanal e as Populações Caiçaras.............................................

5.1.1 Os Pescadores, a Importância da Pesca Artesanal e outras Atividades.. $\quad 31$

5.1.2 As Espécies Capturadas.....................................................................

5.1.3 Os Métodos de Pesca.........................................................................

5.1.4 Os Pontos de Pesca........................................................................... 37

5.1.5 As Variáveis da Pesca: Lua, Maré e Chuva........................................... 38

5.1.6 A Qualidade dos Pesqueiros............................................................. 43

5.2 Etnoictiologia Caiçara......................................................................

5.2.1 As Etnoespécies.............................................................................

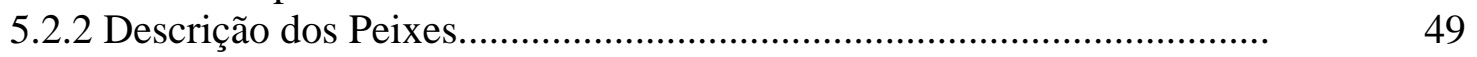

5.2.3 Habitat........................................................................................ $\quad 52$

5.2.4 Presas e Predadores ......................................................................

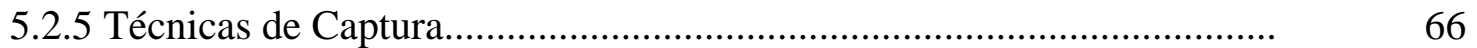

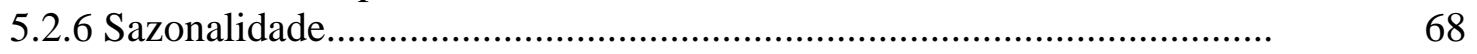

5.2.7 Reprodução................................................................................. 69

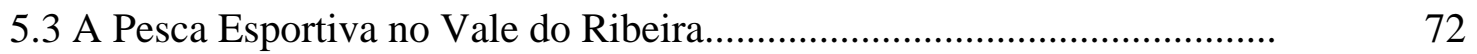

5.3.1 O Perfil dos Pescadores Esportivos.....................................................

5.3.2 Freqüência das Pescarias Esportivas e Tipo de Hospedagem Utilizada. $\quad 74$

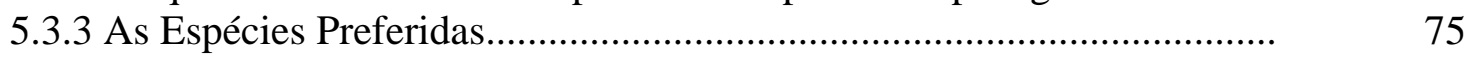

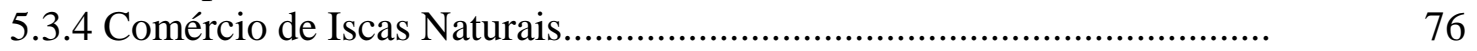

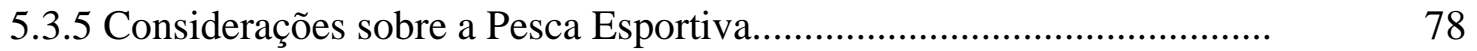

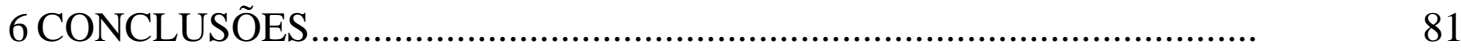

REFERÊNCIAS BIBLIOGRÁFICAS................................................

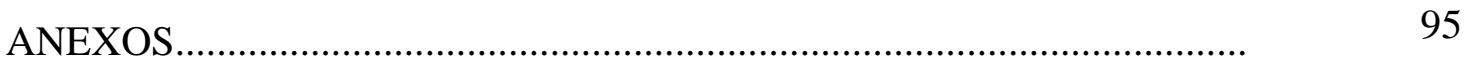




\section{LISTA DE FIGURAS}

1 Área de estudo. Municípios de Iguape, Cananéia e Ilha Comprida, com destaque para as comunidades caiçaras estudadas...............................................

Página

2 Opinião dos pescadores sobre a influência das fases da lua no aumento da produtividade pesqueira (\% de citação nas entrevistas).

3 Opinião dos pescadores artesanais sobre a influência da maré no aumento da produtividade pesqueira (\% de citação nas entrevistas).

4 Opinião dos pescadores artesanais sobre a influência da chuva no aumento da produtividade pesqueira (\% de citação nas entrevistas).

5 Opinião dos pescadores artesanais sobre a qualidade dos pontos de pesca da região (\% de citação nas entrevistas).

6 Opinião dos pescadores artesanais sobre a qualidade dos pesqueiros em relação aos anos anteriores (\% de citação nas entrevistas)..

7 Conhecimento dos pescadores artesanais sobre a diferenciação sexual dos peixes.

8 Relações tróficas do robalo, segundo o conhecimento dos pescadores de Barra do Ribeira, Porto Cubatão e Pedrinhas (os números correspondem às porcentagens de citação nas entrevistas).

9 Relações tróficas da manjuba, segundo o conhecimento dos pescadores da Barra do Ribeira e Jairê (os números correspondem às porcentagens de citação nas entrevistas).

10 Relações tróficas da tainha, segundo o conhecimento dos pescadores de Barra do Ribeira, Carijo, Porto Cubatão e Pedrinhas (os números correspondem às porcentagens de citação nas entrevistas)... 
11 Relações tróficas do parati, segundo o conhecimento dos pescadores de Porto Cubatão e Pedrinhas (os números correspondem às porcentagens de citação nas entrevistas).

12 Relações Tróficas da pescada, segundo o conhecimento dos pescadores de Porto Cubatão e Pedrinhas (os números correspondem às porcentagens de citação nas entrevistas)

13 Relações Tróficas da sororoca, segundo o conhecimento dos pescadores do Carijo (os números correspondem às porcentagens de citação nas entrevistas).....

14 Sazonalidade das espécies, segundo o conhecimento dos pescadores artesanais (\% de citação nas entrevistas).

15 Períodos de reprodução das espécies de peixes segundo o conhecimento dos pescadores (\% de citação nas entrevistas).

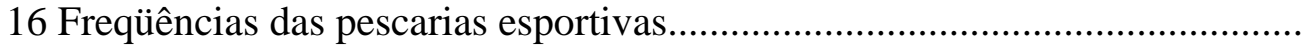

17 Tipo de hospedagem utilizada pelos pescadores esportivos........................ 


\section{LISTA DE TABELAS}

1 Perfil sócio econômico dos pescadores artesanais das comunidades caiçaras estudadas

Página

2 Outras atividades econômicas desenvolvidas pelos pescadores artesanais de Iguape, Cananéia e Ilha Comprida (os valores correspondem a \% de citação nas entrevistas).

3 Espécies de peixes de maior importância para a pesca artesanal (\% de citações nas entrevistas).

4 Métodos de pesca utilizados pelos pescadores artesanais

5 Pontos de pesca utilizados pelos pescadores artesanais

6 Espécies definidas para o levantamento etnoictiológico e seus respectivos números de entrevistas em cada comunidade.

7 Etnoespécies citadas pelos pescadores artesanais

8 Comparação entre o conhecimento dos pescadores sobre a distribuição horizontal dos peixes e a literatura científica (\% de citação nas entrevistas)..

9 Conhecimento dos pescadores sobre a distribuição vertical dos peixes (\% de citação nas entrevistas).

10 Cognição comparada sobre as presas dos peixes. Os valores correspondem a \% de citação nas entrevistas.

11 Predadores dos peixes segundo o conhecimento dos pescadores. Os valores correspondem a \% de citação nas entrevistas.

12 Técnicas de pesca mais utilizadas para a captura das espécies de acordo com o conhecimento dos pescadores. Os números correspondem à porcentagem de citação nas entrevistas 
13 Perfil dos pescadores esportivos entrevistados..........................................

14 Ranking das espécies mais procuradas pelos pescadores esportivos (de acordo com a citação, \%)...........................................................................

15 Espécies de iscas naturais, técnicas de coleta e preço (R\$)(agosto 2003)..... 


\title{
ETNOCONHECIMENTO CAIÇARA E USO DE RECURSOS PESQUEIROS POR PESCADORES ARTESANAIS E ESPORTIVOS NO VALE DO RIBEIRA (SP)
}

\author{
Autora: MILENA RAMIRES DE SOUZA
}

Orientadora: Profa. Dra. SILVIA MARIA GUERRA MOLINA

\section{RESUMO}

A atividade pesqueira é uma forte característica das populações humanas litorâneas, como os caiçaras do litoral sul de São Paulo. Ao realizar a pesca de forma artesanal, esses pescadores exploram o ambiente aquático de forma peculiar. Para manter e recriar seu meio de subsistência, adquirem conhecimentos profundos sobre a natureza e seus ciclos. Em suas atividades produtivas, estabelecem e mantém grande diversidade de interações diretas com o ambiente. Nas últimas décadas, entretanto, essas populações vêm incorporado novas atividades econômicas, como a prestação de serviços. O turismo associado a pesca esportiva eventualmente proporciona renda alternativa para os pescadores. Estes prestam serviços diversos e aplicam seus conhecimentos sobre os recursos pesqueiros à nova prática. Essa realidade traz novos desafios para a população caiçara e seu modo de vida. Diante disso, o presente trabalho teve três objetivos centrais e assim três linas de investigação. (1) Análise da atividade de pesca artesanal em relação: aos métodos e pontos de pesca utilizados, à sazonalidade e espécies de peixes capturadas e às condições ambientais que influenciam a atividade pesqueira, segundo o conhecimento dos pescadores artesanais. Também foram estudados dentro desse objetivo, as relações dos pescadores com outras atividades econômicas. (2) 
Estudo etnoictiológico, abordando aspectos de morfologia e comportamento dos peixes, com ênfase em sua etnoecologia. Foram identificadas ainda, as correspondências e divergências entre o etnoconhecimento caiçara e a literatura cientifica. (3) Caracterização da pesca esportiva praticada nas comunidades caiçaras estudadas, traçando o perfil dos pescadores esportivos. Foram analisadas suas relações com os pescadores artesanais e possíveis influências em modo de vida. A presente pesquisa foi realizada nas comunidades caiçaras da Barra do Ribeira e Jairê (Iguape), Carijo e Porto Cubatão (Cananéia) e Pedrinhas (Ilha Comprida). Nas cinco comunidades estudadas foram constatadas algumas características em comum quanto aos aspectos analisados. A pesca artesanal ainda se caracteriza como uma das principais fontes de renda. Sua prática diária, ainda é bastante freqüente, evidenciando sua forte presença no cotidiano das comunidades caiçaras. Entretanto foram observadas outras atividades econômicas, associadas à pesca esportiva em três das comunidades estudadas. Segundo os pescadores, a produção pesqueira é influenciada por variáveis como fases da lua, marés e precipitações. O etnoconhecimento orienta a atividade pesqueira tradicional e vem sendo aplicado a outras atividades econômicas. Este é o caso da coleta de iscas naturais a serem vendidas aos pescadores esportivos. Ainda existe entre os pescadores artesanais, um extenso conhecimento ecológico sobre os peixes. Também se constatou uma elevada concordância entre o etnoconhecimento e o conhecimento cientifico. Em três das comunidades, vem ocorrendo intensificação do turismo associado à pesca esportiva. Constatou-se que nesses locais, esta vem disputando recursos e espaços com a pesca artesanal. Dessa forma, vem acarretando alterações na rotina dos caiçaras; alterações estas, ainda não avaliadas ecológica e socioculturalmente. A expansão da pesca esportiva requer conhecimento e planejamento para prevenir efeitos ambientais e socioculturais negativos. São necessários estudos sobre os seus impactos na dinâmica das populações locais e estoques pesqueiros.

(O presente trabalho está inserido no projeto: “Os Peixes e Pesca na Mata Atlântica no Sul do Estado de São Paulo”. Este projeto é coordenado pelo Dr. Walter Barrella e financiado pelo Programa Biota/ Fapesp - processo no 99/04529-7). 


\title{
ETHNOKNOWLEDGE CAIÇARA AND FISHERY RESOURCES USE BY ARTISANAL AND SPORTIVE FISHERMEN IN VALE DO RIBEIRA (SP)
}

\author{
Author: MILENA RAMIRES DE SOUZA \\ Adviser: Profa. Dra. SILVIA MARIA GUERRA MOLINA
}

SUMMARY

The fishery characterizes coastal human populations, as the caiçaras from south coast of São Paulo state. By making the fishery in an artisanal method, these fishermen explore the aquatic environment in a peculiar way. To maintain and recreate their subsistence system, the fishermen acquire a considerable and significant knowledge about the nature and its cycles. In their productive activities, they establish and maintain large diversity of direct interactions with their environment. However, over the last few decades these populations have incorporated new economic activities, as service rendering. The tourism associated to sportive fishery its, eventually, an alternative form of income to the fisherman. They provide several forms of services and apply their knowledge about fishery resources to the new activity. Such a new reality brings out new challenges to the caiçara population and its traditional way of life. The present work had three central objectives and so, three lines of investigation. (1) Analysis of the artisanal fishery activity related to the methods and fishery points used, the seasonality and captured fish species and the environmental conditions that influence the fishery activity, according to the artisanal fisherman knowledge. The relationships between the fishermen and other economic activities were also studied. (2) An ethnoictiological study concerning aspects of fish morphology and behavior, emphasizing its 
ethnoecology. The correspondences and divergences between the caiçara ethnoknowledge and the scientific literature were also identified. (3) The characterization of sportive fishery practiced in the studied caiçara communities, tracing the sportive fishermen profile. The relationship with the artisanal fishermen and possible influences in their way of life were also analyzed. The present research was carried out in the caiçara communities of Barra do Ribeira, and Jairê (Iguape city), Carijo, and Porto Cubatão (Cananéia city), and Pedrinhas (Ilha Comprida City). The data collection was carried out by using interviews, direct observations, and biological material collection. In all the five studied communities, some common characteristics related to the analyzed aspects were verified. The artisanal fishery still characterizes itself as one of the main income sources. Its dairy practice is still quite frequent, showing its strong presence in the quotidian of the caiçaras communities. Nevertheless, other economic activities related to the sportive fishery in three of the studied communities were observed. According to the fishermen, the fishery production is influenced by variables as moon phase, tide and rainfall. The ethnoknowledge guides the traditional fishery activity and has been applied to the other economic activities. For instance, the collection of natural fishing bait to sell to the sportive fisherman. There is still a large ecological knowledge about the fishes among the artisanal fisherman. It was also verified a high correspondence between the ethnoknowledge of the artisanal fisherman and the scientific knowledge. In three of the communities studied, tourism associated to sportive fishery has been intensified, competing for resources and spaces with the artisanal fishery, leading to alterations in the routine of the caiçaras, which have not yet been evaluated in ecological and sociocultural terms. The increase of the sportive fishery demands knowledge and planning to prevent negative sociocultural and environmental effects. Studies about its impact on the local population dynamics and fishery stocks are necessary.

(The present work is part of the project: "The Fish and Fishery in the Atlantic Forest on the south of the São Paulo state”. This project is coordinated by the Dr. Walter Barrella and supported by Biota Program/ FAPESP - Grant nº 99/04529-7). 


\section{APRESENTAÇÃO}

Este trabalho é fruto de paixões imensas e de tempos, o mar, a pesca artesanal, o povo do mar e tudo a ele relacionado. O envolvimento começou na graduação e desde então não mais se desfez. As iniciações científicas, mais do que o despertar do interesse foram o grande passo rumo às descobertas e a preparação para o que agora está se tornando uma dissertação, o resultado final de uma pesquisa repleta de aprendizado, experiências, convivências, dedicação e também dificuldades.

Este trabalho está inserido no projeto: “Os Peixes e Pesca na Mata Atlântica no Sul do Estado de São Paulo”, coordenado pelo Dr. Walter Barrella, sediado na PUC Pontifícia Universidade Católica de São Paulo (campus Sorocaba) e financiado pelo Programa Biota/ Fapesp (processo n ${ }^{0}$ 99/04529-7). Tal projeto teve como objetivos a realização de estudos ecológicos sobre a comunidade de peixes, verificando os principais locais de pesca, além da reunião do conhecimento etnobiológico relacionado à pesca praticada pelas populações locais e por pescadores esportivos, bem como a investigação das relações entre a pesca, as atividades de piscicultura, exploração pesqueira e o turismo ecológico praticados nessa região do estado de São Paulo.

A pesquisa foi marcada, do início ao fim, por intensos trabalhos de campo, meticulosos, e exaustivos, os quais resultaram numa avalanche de dados e informações sobre a realidade da pesca e dos pescadores do Vale do Ribeira, bem como sobre a ictiofauna da região.

Assim, esta dissertação representa uma contribuição ao referido projeto e à produção de conhecimento na área, haja visto que busca apresentar a importância e a realidade da pesca e dos pescadores no estudo da natureza e suas relações de usos e conservação dos recursos naturais. 


\section{INTRODUÇÃO}

A atividade pesqueira é uma forte característica das populações humanas litorâneas, como os caiçaras do litoral sul de São Paulo. Através da pesca, os pescadores exploram o ambiente aquático de forma peculiar e adquirem conhecimentos sobre a natureza, além de estabelecer uma grande diversidade de interações com o ambiente. No entanto, nas últimas décadas, as populações caiçaras têm incorporado em seu modo de vida novas atividades econômicas. Neste contexto, a pesca esportiva tem proporcionado uma alternativa de renda para as famílias de pescadores que voltam suas atenções e implicam seus conhecimentos sobre os recursos pesqueiros nesta nova prática.

Estas relações de conhecimento, interação com ambiente, mudanças no modo de vida e na forma de exploração dos recursos naturais, têm sido freqüentemente analisadas através de variados enfoques que abordam aspectos ecológicos, culturais, sócio-econômicos, dentre outros. Sob esta perspectiva, este estudo fundamenta-se numa abordagem interdisciplinar, permitindo estabelecer diálogos e conexões entre as ciências naturais e as ciências humanas, buscando compreender a lógica e a realidade que permeiam a análise das interações entre os pescadores e os recursos pesqueiros.

Para isso, fez-se necessária a apropriação de alguns métodos e abordagens da etnociência, em especial, da etnobiologia e da etnoecologia para construir o conhecimento. Contudo, estas abordagens não são tomadas aqui de forma dogmática, mas sim como ferramentas para a análise das interações existentes entre os pescadores e os peixes. Além disso, através das leituras de Marques (1991; 2001) foi possível observar e acompanhar o amadurecimento da pesquisa etnobiológica e etnoecológica e a sua potencial contribuição neste estudo. Para esse autor, diversos sistemas cognitivos permeiam a etnobiologia e a etnoecologia, uma vez que já superaram as amarras disciplinares e avançam na busca da interdisciplinaridade e da transdisciplinaridade. 
Dada a importância da etnociência, demais contribuições, devem estar sempre presentes nos estudos sobre a relação entre as populações humanas e a natureza. Investigações sobre a relação e(ou) problemas destas populações com os recursos locais devem receber atenção com o intuito de contribuir de alguma forma para as populações. Porém, uma visão de troca e(ou) a necessidade de retribuir devolvendo a populações de pescadores contribuições importantes que possam modificar a realidade vivida, propiciando melhoria de vida, não é uma tarefa fácil. Neste sentido, a análise da pesca esportiva como uma alternativa para estas populações pode apresentar uma relevante contribuição. No entanto, ainda são necessários estudos que expressem a realidade da relação da pesca esportiva com as populações caiçaras. Portanto, a análise destas relações através do estudo pontual de algumas comunidades do Vale do Ribeira é importante. Assim como, a discussão acerca do conhecimento caiçara implicado nas relações com a pesca esportiva, além das práticas de pesca que podem ser úteis para as populações e que podem fornecer subsídios para a organização da atividade pesqueira, bem como para a conservação do ambiente que atualmente vem tendo novas formas de uso dos recursos. 


\section{REVISÃO DE LITERATURA}

\subsection{As Populações Caiçaras}

A população brasileira resulta da miscigenação genética e cultural do colonizador português com o indígena do litoral, ocorrida nas quatro primeiras décadas de colonização, formando uma população de mamelucos que rapidamente se multiplicou. Estes primeiros habitantes mestiços foram moldados principalmente pelo patrimônio milenar de adaptação à floresta tropical dos tupi-guaranis. A chegada do negro africano, como escravo, veio contribuir mais tarde, gerando um contingente mestiço de índios, brancos e negros, que viria a constituir o povo brasileiro. Este processo de mestiçagem explica a origem e a semelhança dos traços culturais dos caipiras, caiçaras e caboclos, nas diferentes regiões do Brasil (Sanches, 1997). Historicamente, a formação das comunidades caiçaras só pode ser entendida no contexto da ocupação do litoral brasileiro e dos ciclos econômicos vividos pelas regiões sul e sudeste (Adams, 2000). Segundo Hanazaki (2001), alguns povoamentos caiçaras são tão antigos quanto as primeiras vilas brasileiras, como por exemplo, a vila de Icapara (Iguape/SP).

A formação de várias das comunidades marítimas e litorâneas no Brasil se deu entre o vasto período que vai do século XVIII ao início do século XX, cujos membros viviam, sobretudo ou parcialmente, de atividade pesqueira. Em tais comunidades, dispersas por todo o litoral, modos de vida e culturas locais específicas puderam emergir, diferenciando seus membros de outros grupos (Silva, 1993). Este é o caso das comunidades caiçaras, cujos habitantes, durante longo período ficaram relativamente isolados na Mata Atlântica e no litoral dos Estados de São Paulo, Rio de Janeiro e Paraná. Desta forma, desenvolveram uma cultura particular que os diferencia da 
comunidades tradicionais do interior desses estados (Diegues, 1988a, Luchiari, 1992, 1997).

O termo caiçara tem origem do tupi guarani caaiçara, que significa o homem do litoral. Para estes povos, inicialmente, essa palavra era utilizada apenas para denominar as estacas colocadas à volta das tabas ou aldeias e o curral feito de galhos de árvores fincados na água para cercar o peixe. Com o passar do tempo, passou a ser o nome dado às palhoças construídas nas praias para abrigar as canoas e os apetrechos de pesca. Só mais tarde, passou a identificar os moradores do litoral dos estados do Paraná, São Paulo e Rio de Janeiro (Diegues, 1988b; Adams, 2000).

As comunidades caiçaras mantinham várias atividades sociais relacionadas ao lazer (cantorias, festas religiosas, comemorações pela colheita). Porém, o desfrute da natureza exclusivamente para lazer (pescar, nadar, mergulhar, caminhar) era mais raro. O caiçara combinava este lazer às suas necessidades de sobrevivência: ao mesmo tempo em que caminhava pela mata podia encontrar um "pau bom” para fazer o seu barco, enquanto pescava podia contemplar o mar e conhecê-lo melhor descobrindo novos pontos de pesca, enquanto plantava e colhia, redescobria os ciclos da natureza e se ajustava a eles. Dessa forma, os caiçaras construíam sua rede de conhecimentos através de uma relação de complementaridade entre homem e ambiente (Luchiari, 1997).

A economia caiçara caracterizava-se tanto como uma oposição à economia indígena como à industrial. Se por um lado, tinha uma produção destinada ao consumo da unidade familiar, por outro, também começava a apresentar uma contribuição mais ampla à economia, através da geração de excedente que era utilizado para adquirir produtos e serviços de que os caiçaras necessitavam, mas não podiam produzir, como ferramentas, habitação, vestuário, sal, entre outros (Marcílio, 1986) ${ }^{1}$.

Até o final do século XIX, as comunidades caiçaras do Litoral Sul do Estado de São Paulo e as caipiras do interior do Vale do Ribeira praticavam amplamente a agricultura itinerante. Já por volta de 1910, com a falência do comércio agrícola, as

\footnotetext{
${ }^{1}$ Marcílio, M. L. 1986. Caiçara: Terra e População. Estudo de demografia histórica e da história social de Ubatuba. São Paulo: Edições Paulinas - CEDHAL, 245p. Citado por Adams, 2000.
} 
comunidades caiçaras voltaram-se às atividades de pesca artesanal, com fins de subsistência, estimulando pouco a pouco o comércio de pescado (Sanches, 1997).

As populações caiçaras ocupam uma variedade da habitats e ecossistemas. Em termos gerais, a região norte de São Paulo é diferente da região sul. Dadas as vastas planícies formadas pela bacia do Rio Ribeira de Iguape, no sul do Estado são mais abundantes as formações de restingas e mangues, ao passo que ao norte predomina um litoral rochoso com pequenas praias, onde a Serra do Mar se aproxima mais do litoral (Diegues, 1988b). Entretanto, comunidades caiçaras têm em comum elementos sociais e culturais de bases históricas e de influências étnicas de índios e portugueses, como o comportamento cultural e a linguagem (Begossi, 1992).

Recentemente, populações caiçaras da costa sudeste do Brasil têm experimentado mudanças em seu modo de vida em função de fatores como a intensificação da pesca comercial, o turismo e a efetivação de áreas protegidas (Begossi, 1995). Estas comunidades passaram a chamar a atenção de pesquisadores e de órgãos governamentais tanto em virtude das ameaças cada vez maiores à sua sobrevivência material e cultural como em virtude da contribuição histórica que estas populações têm dado à conservação da biodiversidade, pelo seu conhecimento da fauna e da flora e pelos sistemas tradicionais de manejo dos recursos naturais de que dispõem.

Essas comunidades encontram-se hoje ameaçadas em sua sobrevivência física e material por uma série de fatores e processos. Uma das ameaças a essas comunidades e ao exercício de suas atividades tradicionais provém do avanço da especulação imobiliária, iniciado nas décadas de 1950 e 1960, sobretudo com a construção de residências secundárias ao longo do litoral. A especulação imobiliária privou grande parte dos caiçaras de suas posses nas praias, obrigando-os tanto a trabalhar como caseiros e pedreiros, quanto a se mudar para longe do local de trabalho, dificultando as atividades pesqueiras. Além disso, o turismo de massa, sobretudo no litoral centro-norte de São Paulo, contribuiu para a desorganização das atividades tradicionais, criando uma nova estação ou safra nos meses do verão, quando muitos caiçaras se transformam em prestadores de serviços (Diegues \& Arruda, 2001). 
No entanto, apesar dos problemas mencionados, das restrições ambientais e do reduzido acesso às áreas de extrativismo, as comunidades caiçaras ainda hoje dependem de atividades exercidas tanto na mata como nos estuários e no mar. Um estudo realizado pelo NUPAUB - Núcleo de Pesquisas sobre Populações Humanas e Áreas Úmidas Brasileiras (Diegues \& Arruda, 2001), mostra que dos trabalhos publicados sobre os caiçaras, cerca de $63,5 \%$ de um total de 104 , indicam ser o extrativismo uma atividade realizada por estas populações.

O extrativismo caiçara se dá, de um lado, no mar, em restingas e estuários e está associado à pesca e coleta de crustáceos e moluscos. De outro lado, ocorre nem terra, onde um grande número de espécies de árvores, arbustos, flores, cipós e frutas são utilizados tanto para o uso doméstico quanto comercial. Com os recursos florestais são fabricados equipamentos de pesca, instrumentos de lida na lavoura e de uso doméstico, além do artesanato para a venda. Alguns desses equipamentos são fabricados pelos homens, ao passo que outros itens como cestarias, cerâmicas e remédios caseiros são de responsabilidade feminina (Diegues, 2002). Segundo Hanazaki (2002), o conhecimento caiçara sobre os recursos naturais engloba tanto ambientes aquáticos como terrestres, incluindo mais de 300 espécies de animais e plantas. A dependência que os caiçaras possuem dos recursos aquáticos para as atividades de pesca e extrativismo faz com que estes acumulem um detalhado conhecimento sobre a dinâmica do ecossistema. Desta forma, o aprendizado sobre o trabalho de pesca tem início durante a infância, ou seja, acompanhando o pai ou parente nas atividades pesqueiras, ou pescando individualmente no estuário, que oferece mais segurança que o mar aberto por ser mais abrigado dos ventos e ondas.

A pesca artesanal é uma das principais características da cultura caiçara. Através dela as populações caiçaras exploram o ambiente natural de forma peculiar e assim, adquirem conhecimentos sobre a natureza (Diegues, 1983; 1995). Segundo Seixas \& Begossi (2000), o comportamento dos pescadores e as estratégias para obter os recursos pesqueiros são aspectos importantes nos estudos sobre manejo de ecossistemas aquáticos quando correlacionados aos estoques pesqueiros. Marques (2001) afirma que alguns grupos de pescadores possuem um conhecimento acurado e compatível com o 
conhecimento ictiológico acadêmico. Tal conhecimento é suficiente para otimizar o seu comportamento em um sistema de presa/predador culturalmente intermediado e habilitando-os à manipulação sustentável de cadeias tróficas. Para Maldonado (1986), o homem se apropria de maneiras peculiares dos ambientes produtivos e do mundo em que vive, através do conhecimento que tem da natureza que explora para sobreviver e do seu trabalho no mar.

\subsection{A Pesca Artesanal}

Os pescadores artesanais estão espalhados pelo litoral, em rios e lagos e têm seu modo de vida assentado principalmente na pesca, ainda que exerçam outras atividades econômicas (Diegues \& Arruda, 2001).

A Organização Internacional do Trabalho define como pescadores os trabalhadores que se dedicam à captura de pescado e exercem as funções de membros das tripulações de barcos pesqueiros, executando diversas tarefas de pesca de altura (em mar aberto) no caso dos pescadores marítimos ou tarefas específicas da pesca de água doce e águas costeiras (Maldonado, 1986). Segundo Diegues (1988b), a pesca artesanal é definida como aquela em que o pescador sozinho ou em parcerias participa diretamente da captura de pescado, utilizando instrumentos relativamente simples. Os pescadores artesanais retiram da pesca sua principal fonte de renda, ainda que sazonalmente possam exercer atividades complementares. Entretanto, ela abrange tanto o segmento das atividades pesqueiras caracterizadas pelo objetivo comercial combinado com o de obtenção de alimento para a família, como o segmento representado pelas operações de pesca realizadas com finalidade exclusivamente comercial. Neste último caso, ocorre, em geral, como alternativa sazonal à cultura agrícola, caracterizando-os como pescadores agricultores (Dias Neto \& Dornelles, 1996). Apesar do grande número de pescadores artesanais viverem em comunidades litorâneas, como por exemplo, os caiçaras, alguns moram em bairros urbanos ou periurbanos, construindo dessa forma uma solidariedade baseada na atividade pesqueira (Diegues \& Arruda, 2001).

A pesca artesanal é responsável por um elevado nível de emprego nas comunidades litorâneas nos setores de captura, beneficiamento e comercialização do 
pescado. Esta atividade também é importante na manutenção da grande diversidade cultural das comunidades de pescadores (Diegues, 1993). Quando praticada de forma artesanal opera dentro dos limites impostos pelo ambiente, tanto devido ao baixo esforço da pesca, quanto à heterogeneidade e incertezas do ambiente (Begossi, 1992; Diegues, 1988b).

No Brasil, a pesca artesanal está ligada historicamente à influência de três correntes que foram básicas para a nossa formação cultural: a indígena, a portuguesa e a negra (Silva et al., 1990). Da indígena herdamos o preparo do peixe para a alimentação, o feitio das canoas e jangadas, as flechas, os arpões e as tapagens ${ }^{2}$; da portuguesa, os anzóis, pesos de metal, redes de arremessar e de arrastar e da negra, a variedade de cestos especiais (Diegues, 1983).

A pesca artesanal encontra-se em contraste com a pesca industrial por ser exercida com métodos simples. As características dos pescadores artesanais e industriais são bastante diversificadas tanto em relação aos habitats onde atuam quanto aos estoques que exploram (Begossi, 1992; Maldonado, 1986). Mesmo a pesca artesanal, como atividade econômica associada ao mar, relaciona-se não só ao trabalho e à sobrevivência, mas a uma multiplicidade de relações sociais: parentesco, festividades, atividades coletivas como a pesca da tainha, a divisão do produto da pesca, a limpeza do pescado, a salga, entre outras (Luchiari, 1997).

A pesca artesanal disputa, hoje, recursos com grandes empresas de pesca industrial, que possuem infra-estrutura muito desenvolvida referente aos barcos e equipamentos de pesca (Marques, 2001). Nogara (2000) aponta que a crise no setor pesqueiro é de escala mundial. Inúmeros países vêm enfrentando essa situação e desenvolvendo estratégias de gestão que visam um maior controle sobre os métodos de pesca, o volume capturado, a definição das épocas de defeso e, sobretudo a proteção dos ecossistemas propícios à reprodução e recrutamento dos organismos marinhos.

As transformações que vão ocorrendo nas unidades pesqueiras artesanais traduzem não somente mudanças de instrumentos e aparatos tecnológicos, que

2 Trata-se de uma arte de pesca realizada com rede de malhas e tamanhos variados, utilizadas em rios e/ou desembocaduras de rios de modo a “tapar” todo o ambiente por onde o peixe passa, no intuito de capturá-lo. 
representam a substituição do homem pela máquina, como por exemplo, a passagem da manufatura à industria, mas também interferem no modo de vida dos pescadores. A própria rotina diária de suas tarefas domésticas e a dinâmica de outras ocupações nas comunidades seguem o ritmo do trabalho pesqueiro, orientado principalmente pelos fenômenos naturais e pela capacidade de reprodução da natureza. Este processo de transformação da pesca artesanal, no entanto, tem-se apresentado de modo descontínuo e contraditório, moldando diferentemente, as estratégias de reprodução e as alternativas disponíveis às várias comunidades pesqueiras do litoral brasileiro (Costa, 1999).

Mesmo assim, a pesca artesanal é uma das maiores fontes de proteína animal para o consumo humano. A produção oriunda do mar contribuiu, no período de 1975 a 1994, com um mínimo de 67,7\% e um máximo de 85,2\% da produção total de pescado do Brasil (Dias Neto \& Dornelles, 1996). Na região do complexo estuarino lagunar Iguape-Ilha Comprida-Cananéia, a pesca artesanal destaca-se como o fator mais importante nos processos de utilização econômica e social dos recursos naturais (Serralheiro et al., 2000). Na região, ela é dividida em dois tipos: a praticada no mar e áreas próximas às praias e a exclusivamente estuarino-lagunar. Nas pescarias próximas às praias, utiliza-se bateiras ou canoas a motor e as artes de pesca são redes de arrasto, malhadeiras e espinhel. A pesca exclusivamente estuarina lagunar utiliza embarcações de diversos tamanhos e modelos, desde voadeiras até canoas, que podem ser motorizadas ou não. As artes de pesca incluem o cerco-fixo, espinhel, rede de emalhe e gerival. Esta última difere basicamente da pesca de mar, por utilizar o cerco-fixo como principal método de captura. A produção dentro do estuário é baixa na maioria das vezes, excetuando-se aquelas das safras, tais como as de tainha e de parati (Mendonça \& Katsuragawa, 2001).

Embora a pesca no estado de São Paulo represente a maior porção da frota brasileira, participando com cerca de 60\% do volume de pescado nacional (Dias Neto \& Dornelles, 1996). Ainda existe uma grande lacuna nesta área de pesquisa, faltando informações básicas sobre o tamanho, estrutura e funcionamento da frota, artes e métodos de pesca, espécies exploradas, dados de produção e captura neste segmento da pesca (Bertozzi, 2002). 
Em relação aos pescadores, no Brasil, os trabalhos sobre comunidades pesqueiras começaram a se tornar mais numerosos a partir da década de 1970. Anteriormente, os trabalhos eram de caráter folclórico ou essencialmente antropológico onde se ressaltava a homogeneidade social e a tradição. A partir da década de 1970, a pesca e as comunidades de pescadores começaram a ser percebidas dentro de um contexto mais amplo da sociedade nacional, da penetração das relações capitalistas no setor, dos conflitos entre as diversas modalidades de pesca (Diegues, 1995), além dos estudos que valorizam o conhecimento dos pescadores.

\subsection{A Pesca Esportiva}

Com o passar dos anos, o ser humano foi alterando seu modo de vida e sua relação com o ambiente, distanciando-se de uma relação mais direta com a natureza. A paisagem natural tornou-se um refúgio a ser "preservado”, na intenção do usufruto, para o descanso do estresse dos grandes centros urbanos.

O turismo em toda extensão do litoral brasileiro aparece como alternativa de lazer e de reaproximação das pessoas, que habitam as grandes cidades, com o ambiente natural, constituindo-se uma importante atividade econômica para as regiões receptoras.

O ecoturismo surgiu como forma de reaproximar da natureza pessoas que vivem "presas” às cidades. O ecoturismo é uma forma de turismo inspirada, principalmente na história natural de uma área, incluindo sua cultura nativa (Pires, 1998). Em termos gerais, o turismo de natureza, contribuiria para a conservação, através de geração de fundos para as áreas protegidas e para populações locais, criando oportunidades de emprego para as comunidades locais e promovendo educação ambiental.

A definição criada pela EMBRATUR-Instituto Brasileiro de Turismo - (2001), entende ecoturismo como o segmento da atividade turística que utiliza, de forma sustentável, o patrimônio natural e cultural, incentiva sua conservação e busca a formação de uma consciência ambientalista através da interpretação do ambiente, promovendo o bem estar das populações envolvidas. 
Contudo, como qualquer atividade econômica voltada para o mercado, as dimensões do turismo e conseqüentemente do ecoturismo vão além destas definições. $\mathrm{O}$ turismo desenvolve-se sob a ótica do capital, "transformando assim a natureza em mercadoria” (Luchiari, 1997, p.136). A análise desta atividade para a referida autora, não envolve apenas o consumo de bens, num restritivo âmbito econômico, mas complexas relações sociais. Na verdade, grupos sociais determinados demandam formas diferenciadas de lazer, envolvendo estratégias de organização, produção e consumo, e relações sociais de trabalho.

O turismo passa a vender paisagens de diferentes espaços, especialmente das áreas litorâneas. Seguindo as exigências do capital, estes lugares vão se adequando aos diferentes níveis de empreendimentos de infra-estrutura hoteleira, lazer, transportes, entre outros, implantados com a finalidade de atender a dinâmica desta atividade e oferecer os serviços necessários aos visitantes.

A crescente expansão do turismo nas áreas litorâneas tem provocado alterações na paisagem dos ecossistemas costeiros em todo o litoral brasileiro. As mudanças ocorridas nestes ambientes provocam fragilidades significativas na dinâmica sóciocultural das populações locais, levando ao rompimento de práticas tradicionais de subsistência e conduzindo-as ao circuito da atividade turística. Porém, de acordo Luchiari (1997), estas populações não conseguem acompanhar esse processo, do qual muitas vezes são excluídas. A esperança de ascender economicamente num mercado altamente especializado, se configura na frustração da exclusão e da expropriação. Assim, passam a desenvolver atividades informais e sazonais, vivendo segregadas dentro do seu próprio espaço.

Entre os tipos de turistas que buscam um contato mais próximo com a natureza encontra-se os pescadores esportivos. Estes afluem aos milhares, atraídos pelos recursos ictiofaunísticos e pela beleza litorânea. Muitos procuram não só os clubes de pesca, mas também as vilas onde, além do bar, do guia ou do "rancho", acabam encontrando lugar para suas residências de veraneio (Ribaric, 1996).

A pesca esportiva pode ser considerada uma “paixão nacional” e está hoje, bastante associada ao conceito de qualidade de vida, no qual a interação com a natureza, 
constitui-se num pressuposto básico. Conforme Dias Neto \& Dornelles (1996), ela é praticada ao longo de todo o litoral brasileiro, com a finalidade de turismo, lazer ou desporto. Além disso, o produto dessa atividade não pode ser comercializado ou industrializado. Sua concentração é mais significativa em áreas próximas às grandes cidades litorâneas. Em comunidades caiçaras do litoral paulista, a pesca esportiva tem representado uma fonte alternativa de renda que propicia "melhoria de vida” (Prado, 1999; Ribaric, 1996).

Mendonça \& Katsuragawa (2001) observaram que na região do complexo estuarino lagunar de Iguape-Cananéia, a pesca esportiva (também chamada de amadora - muito embora vários pescadores esportivos tenham o registro de profissionais) é desenvolvida por turistas, que utilizam voadeiras e lanchas para o transporte, com motores que variam desde 15 HP até 135 HP. Os autores ainda estimam que existam 170 embarcações voltadas à pesca esportiva, atuando no estuário com pesca de vara (molinetes e carretilhas), gerival e tarrafas.

A pesca esportiva chega a ter, em alguns casos, importância econômica maior que a comercial, em dólares e em empregos, mobilizando estruturas sociais e burocráticas com facilidade. Com isso, observa-se a ascensão desta modalidade de pesca, sendo cada vez mais freqüente a liberação do peixe. O pescador retém apenas o que vai comer de imediato, assegurando a manutenção e crescimento de estoques e a diversão para todos. Observa-se que a pesca esportiva no exterior vem sendo desenvolvida dentro da premissa de conservação ambiental, favorecendo assim, o ingresso de bilhões de dólares na referida atividade e garantindo o seu crescimento.

No Brasil, o pescador esportivo está se “educando” rapidamente, mas, sendo esta uma atividade amadora, o seu desenvolvimento não encontra reconhecimento oficial (Dias Neto \& Dornelles, 1996). Embora, algumas associações desportivas de classe estejam sendo instituídas a partir de membros da sociedade civil, estas têm apresentado interesses relacionados à conservação das espécies e à luta pela defesa dos recursos pesqueiros existentes. Se bem conduzida, a pesca esportiva no Brasil movimentará cada vez mais recursos, além de contribuir para a conservação do meio ambiente (Prado, 1999). 
Sob outra perspectiva, não se pode deixar de considerar que a intensificação turística pode ocasionar um crescimento acelerado e desordenado, acarretando uma série de problemas ambientais, alterando as relações sociais e a cultura das comunidades. O turismo, por meio da sua dinâmica, tem sido um dos principais responsáveis pela transformação das paisagens litorâneas, cujos aspectos ambientais e culturais são modificados continuamente, revelando os desencontros das práticas sócio-ambientais, observadas a exemplo, nas mudanças ocorridas no modo de vida dos pescadores artesanais.

Fazendo um elo entre a intensa discussão sobre sustentabilidade ${ }^{3}$ e os impactos ambientais e sociais causados pelas atividades turísticas, percebe-se que tais atividades necessitam ser colocadas no caminho da sustentabilidade. No entanto, estes caminhos devem ser analisados criticamente, já que o turismo se baseia num intenso consumo ambiental, cultural e social, seja o turismo rural, de aventura, o urbano, a pesca esportiva, ou em todos os seus mais variados desdobramentos.

Tais questões de sustentabilidade relacionadas à atividade de pesca esportiva devem perpassar os vários aspectos das relações humanas, do ambiente e dos peixes. Deve-se considerar a combinação de dimensões econômicas, sociais, políticas, culturais, tecnológicas e as potencialidades ambientais, em prol de uma sustentabilidade aliada à melhoria de vida das populações locais.

Assim, para a avaliação da sustentabilidade da pesca esportiva deve-se considerar os níveis de emprego que ela pode gerar (salários, especializações, funções etc), na qualidade de vida (em seus aspectos físicos e humanos), no poder de consumo, na preservação do patrimônio cultural e natural, na educação ambiental. Ou seja, as implicações e intervenções necessárias para sua regulamentação e planejamento.

\subsection{Interações entre as Populações Humanas e a Natureza}

A diversidade de interações que as culturas humanas possuem com o ambiente tem sido tema para trabalhos com enfoques variados. As relações de conhecimento e

\footnotetext{
${ }^{3}$ Este trabalho não tem como objetivo discutir as teorias de desenvolvimento sustentável, o termo "sustentabilidade" usado baseia-se em reflexões de autores como Sachs $(1986 ; 1998)$ e Leff $(2000 ; 2001)$ que apontam que a busca da sustentabilidade deve abranger várias dimensões: ambiental, social, política, econômica e cultural.
} 
ação entre populações e seu ambiente podem ser estudadas tanto do ponto de vista das ciências biológicas como das ciências sociais. Sob esta perspectiva, a ecologia humana e a etnobiologia, buscam uma integração entre as diferentes ciências e(ou) disciplinas que tratam as relações homem-ambiente. Segundo Marques (2002), a etnobiologia constituise de campos interdisciplinares, cruzamentos de saberes que geram novos campos e novos cruzamentos diferentes da simples interface biológico/antropológico até então apontada em muitos trabalhos.

A etnobiologia e a etnoecologia se posicionam numa interface com as tradicionais disciplinas da academia e podem efetivamente contribuir para os debates científicos atuais relativos à diversidade biológica e cultural (Albuquerque, 2002). As conexões realizadas a partir do cruzamento dessas ciências levarão a análises mais abrangentes no âmbito sócio-cultural, ecológico, econômico, entre outros.

\section{Ecologia Humana}

Estudos de ecologia humana são apropriados para entender as interações entre populações humanas e os recursos naturais. O contato direto com os recursos, a observação diária desses recursos e a dependência econômica dos recursos aquáticos e da vegetação são relações ecológicas em seu sentido estrito (Begossi, no prelo). Dessa forma, o principal objetivo da ecologia humana é analisar o uso de recursos por populações humanas, com o intuito de entender a interação dessas populações com o ambiente, além de buscar entender processos adaptativos de populações humanas, preocupando-se com os meios pelos quais essas populações se mantêm e se reproduzem em seu ambiente.

Em Ecologia Humana empregam-se conceitos das áreas biológica e social, bem como são abordados aspectos físicos, políticos e sócio econômicos relativos às populações estudadas (Adams, 2000; Moran, 1990). Nos estudos de ambientes e populações urbanas, a Ecologia Humana também se faz importante. Porém, nestes casos, a maioria dos recursos deixa de ser obtida diretamente da natureza, tornando as relações analisadas mais econômicas do que ecológicas (Begossi, 1995; Begossi, no prelo). 
Sob esta perspectiva, a Ecologia Humana tem analisado as interações entre as populações humanas e o ambiente, empregando conceitos da ecologia, mas não se restringindo a mais um dos sub-campos da biologia. Ela propõe uma integração entre as ciências biológicas e as ciências humanas, para fornecer instrumentos eficazes no estudo da relação homem-ambiente. A partir dessa integração, ela desenvolve metodologia e sistemática próprias. Várias áreas como antropologia, geografia, sociologia, psicologia, entre outras, têm realizado estudos de ecologia humana. E estes estudos apresentam linhas de pesquisa e abordagens como: ecologia de sistemas, ecologia evolutiva, ecologia cultural, antropologia ecológica, psicologia ambiental, etnobiologia e etnoecologia, modelos de subsistência, sociobiologia, modelos de transmissão cultural e ecologia aplicada (Begossi, 1993; Kormondy \& Brown, 2002).

Todas as abordagens da ecologia humana têm em comum uma base ecológica com conteúdo biológico forte. Para isso, conceitos e modelos analíticos de ecologia geral contribuem de maneira relevante. Estas diversas linhas de pesquisa podem se complementar, pois abordam perguntas diferentes e têm metodologias também diferentes, ou seja, nenhuma se propõe a explicar todos os aspectos da interação humana com o ambiente, mas cada uma contribui para ampliar o conhecimento existente sobre o assunto. Essas características se evidenciam no paradigma da nova-ecologia, a qual tenta reintegrar as análises de adaptação cultural aos estudos da ecologia geral, e na biologia de populações humanas, incluindo a ecologia evolutiva, na qual todos os processos adaptativos humanos, comportamentais e biológicos, são considerados no entendimento de como as populações humanas se adaptam ao ambiente (Begossi, 1993; Kormondy \& Brown, 2002).

\section{Etnobiologia e Etnoecologia}

A Etnobiologia representa o estudo do conhecimento e das conceituações desenvolvidas por qualquer sociedade a respeito da biologia (Posey, 1986; Diegues, 1998). Ela estuda o modo como determinadas sociedades humanas, ditas tradicionais ou locais, classificam, identificam e nomeiam seu ambiente (Mourão \& Nordi, 2002a). 
A etnobiologia ainda não respondeu adequadamente aos questionamentos colocados pelos epistemólogos da ciência (Bandeira, 2001), em relação à definição e aplicação de metodologias e teorias. Berlin (1992) apontou para o fato de não existirem definições especificamente aceitas sobre a etnobiologia. O que se aceitava até então, era uma definição bastante ampla da complexidade das relações entre as sociedades humanas com o ambiente. Posey (1986) também foi um dos principais autores que buscou definições para a etnobiologia, enfatizando um compromisso político-ideológico e ético com relação ao papel que a etnobiologia deve desempenhar. Seu objetivo deve ser o de prover um arcabouço teórico para integrar os diferentes sub-campos das ciências sociais e naturais com outros sistemas científicos. Segundo este autor, do ponto de vista filosófico, a etnobiologia serve de mediadora entre as diferentes culturas, como uma disciplina dedicada à compreensão e respeito mútuo entre os povos.

No entanto, estas definições não compreendem os aspectos epistemológicos e metodológicos questionados de modo que a etnobiologia pode ser confundida ou sobreposta a alguns enfoques teórico-metodológicos mais recentes, como é o da etnoecologia. Segundo Bandeira (2001), essa sobreposição é o resultado do rápido desenvolvimento da etnobiologia, assim como a proliferação de escolas, enfoques e tendências teóricas, o que caracteriza o estado atual de desenvolvimento de disciplinas.

Para Toledo (1992) ${ }^{4}$ e Nazarea (1999), a etnoecologia é o estudo dos conhecimentos, estratégias, atitudes e ferramentas que permitem às diferentes culturas produzir e reproduzir as condições materiais de sua existência social através de um manejo apropriado dos recursos naturais. Ela caracteriza-se como um enfoque ou abordagem teórico-metodológica no estudo da relação sociedade-natureza que enfatiza o papel da cognição no comportamento humano, apresentando-se como uma ferramenta útil para analisar problemas relacionados com o manejo, sustentabilidade, conservação e direito de propriedade intelectual.

Marques (2001: p.49) encontra uma definição que mostra os reais objetivos da etnoecologia como ciência e (ou) disciplina:

4 Toledo, V.M. 1992. What is Ethnoecology? Origins, Scope and Implications of arising Discipline. Etnoecológica 1: 5-21, citado por Bandeira (2001). 
“Etnoecologia é o estudo das interações entre a humanidade e o resto da ecosfera, através da busca da compreensão dos sentimentos, comportamentos, conhecimentos e crenças a respeito da natureza, característicos de uma espécie biológica (Homo sapiens) altamente polimórfica, fenotipicamente plástica e ontogeneticamente dinâmica, cujas novas propriedades emergentes geram-lhe múltiplas descontinuidades com o resto da própria natureza. Sua ênfase, pois, deve ser na diversidade biocultural e o seu objetivo principal, a integração entre o conhecimento ecológico tradicional e o conhecimento ecológico científico”.

As definições de etnobiologia (Posey, 1986; Berlin, 1992) e etnoecologia (Marques, 2001; Toledo, 1992; Nazarea, 1999) mostradas aqui podem, segundo Bandeira (2001), nos levar a concluir que estas têm aspectos em comum e estabelecem como enfoque principal dessa disciplina, as relações sociedade-cultura-natureza. Para Descola $(1996)^{5}$, a etnobiologia busca entender basicamente os mesmos problemas centrais de outras disciplinas, enfoques, tradições e escolas, como a etnoecologia, a ecologia humana, dentre outras.

Se analisarmos as diferenças entre essas definições, podemos encontrar abordagens que dão ênfase a aspectos específicos das inter-relações, sejam eles cognitivos, simbólicos, adaptativos etc., bem como, a linguagem que utilizam, próprias de cada campo ou tomadas emprestadas de outras disciplinas (Bandeira, 2001).

As dificuldades de se delimitar epistemologicamente o campo científico da etnobiologia e da etnoecologia estão fundadas em sua natureza interdisciplinar e em seu recente desenvolvimento teórico-metodológico. Portanto, as ferramentas de que dispõem pertencem a diferentes campos científicos (antropologia, botânica, zoologia, ecologia, história, geografia). No entanto, segundo Marques (2002), a etnobiologia e a etnoecologia não são um conjunto de estudos na interface biológico/antropológico e sim

\footnotetext{
${ }^{5}$ Descola, P. 1996. Constructing Nature: Symbolic Ecology and Social Practice. In: P. Descola, e G. Pálsson, (eds.). Nature and Society. Anthropological Perspectives. $1^{\mathrm{a}}$ ed. London: Routledge. Citado por Bandeira, (2001).
} 
campos interdisciplinares, cruzamentos de saberes, que geram novos campos, novos cruzamentos. Do ponto de vista epistemológico, isto é de suma importância, pois começa a se configurar uma resposta concreta à crise do paradigma cartesiano de disciplinas gerando disciplinas.

A etnoictiologia pode incrementar o nível de conhecimento a respeito da ecologia e das inter-relações entre os organismos (Begossi et al., 2002). Com base nisto, este trabalho enfatiza aspectos biológicos e ecológicos das relações entre os pescadores e os peixes. Assumiu-se portanto, como referencial teórico-metodológico, tanto a etnobiologia como a etnoecologia, não como sinônimos, mas como abordagens com enfoques em comum e que se complementam para concretizar as análises propostas.

Assim, as abordagens etnoecológicas foram tomadas neste trabalho sob a luz das contextualizações feitas por Marques (2001: p.15):

“... a etnoecologia tem uma proposta abrangente, pois apresenta aspectos como: a) a aceitação de que a pesquisa etnoecológica pode ser realizada em qualquer ecossistema, e em qualquer contexto sócio-cultural; b) o reconhecimento da etnoecologia como um campo de cruzamento de saberes; c) integração entre diversas disciplinas e em especial da biologia com a antropologia; d) a insistência de uma metodologia cientificamente enquadrável, mas que permita transgressões responsáveis (integrando subjetividade e objetividade) e heterodoxias assumidas (integrando razão $e$ emoção); e) o enfrentamento da quantificação necessária, porém enfatizando o tratamento qualitativo de realidades ocultáveis pela insuficiência da fala dos números”.

\section{As Correntes de Pensamento da Etnobiologia e Etnoecologia}

A Etnobiologia possui diferentes correntes de pensamento. Entre estas se destaca a dos mentalistas, que argumentam que a população conhece os organismos através da convivência e observação direta e que os sistemas de classificação são orientados intelectualmente. Berlin, um dos autores que adotam essa perspectiva, busca 
elucidar os princípios universais que determinam os padrões de classificação humana, assumindo que a classificação etnobiológica é dirigida pela percepção (Silvano, 1997; Nazarea, 1999). Outra corrente é a dos utilitaristas, que consideram que o conhecimento etnobiológico é influenciado pela utilidade dos organismos, sendo que as populações humanas irão estabelecer classificações mais detalhadas e complexas com relação aos animais e plantas que são relevantes para sua sobrevivência. Segundo Ellen (1993 apud Nazarea, 1999), outras áreas da experiência humana, além da intelectual, influenciam a classificação e o significado atribuído a um dado recurso e sua importância para uma dada população. Este autor assume que as relações culturais modelam as classificações, ou seja, as classificações seriam adaptadas a um contexto e situação dinâmicos e teriam importância prática para seus usuários, resultando da interação entre a cultura e as descontinuidades do mundo concreto, caracterizando os sistemas de classificação como um campo imerso em um amplo contexto de crenças e práticas sociais. Nazarea (1999), aponta autores como Hunn, Ellen e outros como representantes dessa abordagem que busca compreender como a cultura modela a cognição e exerce influência nos comportamentos humanos.

Adams (2000) resume pressupondo que os ideacionistas ${ }^{6}$ (sic) acreditam que o conhecimento etnobiológico, especialmente aquele ligado à classificação da biodiversidade, é motivado fundamentalmente de maneira cognitiva. Ou seja, o homem, em qualquer ambiente, reconhece a estrutura e a ordem inerentes ao mundo biológico, independente de qualquer valor prático que as plantas e animais possam possuir. A segunda linha, dos utilitaristas, acredita que o principal objetivo da classificação etnobiológica é ajudar as populações humanas a se ajustarem a seus respectivos habitats, nomeando apenas aquelas espécies animais e vegetais que têm conseqüências práticas, guardando uma correlação positiva entre o grau de detalhamento na classificação e a relevância prática para a adaptação humana, dos organismos em questão.

Tratam-se, na verdade, de abordagens que respondem a questões diferentes. Segundo Nazarea (1999), não há razão para que os seres humanos não possam operar em ambos os níveis seqüencialmente ou mesmo simultaneamente. Apesar de reconhecer 
que não há um verdadeiro antagonismo entre estas duas abordagens, no presente trabalho assume-se o enfoque utilitarista, por considerá-lo mais adequado para se atingir os objetivos propostos, ou seja, o conhecimento dos pescadores em relação aos peixes mais capturados e comercializados nas comunidades estudadas.

\section{Etnoictiologia}

Dentro da etnobiologia, surgiram vários sub-campos que tratam de domínios específicos do etnoconhecimento, como a etnobotânica, a etnozoologia, a etnoentomologia, a etnofarmacologia, dentre outros. A maior parte dos trabalhos em etnobiologia concentra-se na área de etnobotânica, inclusive no estudo de plantas associadas a remédios (etnofarmacologia). Na etnozoologia, a maioria dos estudos é de etno-ornitologia e etnoictiologia (Posey, 1992; Adams, 2000). A etnoictiologia é o ramo da etnobiologia que trata das interações e inter-relações que os grupos humanos estabelecem e mantém com os peixes (Silvano, 1997). Marques (2001) afirma ainda que a etnoictiologia pode ser interpretada como a busca da compreensão do fenômeno da interação entre o homem e os peixes, englobando aspectos tanto cognitivos quanto comportamentais. Para Posey (1986), a etnoictiologia é vista como o estudo da inserção dos peixes em uma dada cultura.

Estudos de etnoictiologia contribuem para encontrar novas espécies e para o estudo do comportamento de alguns peixes, bem como podem contribuir, através do conhecimento popular, para a conservação da biodiversidade (Begossi \& Figueiredo, 1995; Clauzet, 2003). Tal contribuição é especialmente bem-vinda em países tropicais como o Brasil, onde os peixes consistem em um grupo animal útil como alimento e que apresenta grande diversidade biológica (Begossi et al., 2002).

Dentre os trabalhos mais recentes, estão alguns relacionados a etnoclassificação de peixes por pescadores artesanais como os realizados na Ilha Grande, litoral sudeste do Brasil (Seixas \& Begossi, 2001), no litoral nordeste brasileiro Marques (1991, 2001); com os pescadores de Siribinha/BA (Costa Neto \& Marques, 2000c); na Baía de Sepetiba/RJ (Paz \& Begossi, 1996); no Rio Tocantins (Begossi \& Garavello, 1990) e

\footnotetext{
${ }^{6}$ Denominação utilizada por Adams (2000) para designar a corrente de pensamento dos mentalistas.
} 
também no Estuário do Rio Mamanguape/PB (Mourão, 2000). Segundo Mourão \& Nordi (2002b), da mesma forma que a taxonomia científica, a classificação etnobiológica traduz-se num verdadeiro depósito de informações, na medida em que contém uma riqueza enorme de informações sobre a biologia, ecologia e etologia de diversos grupos de animais e plantas.

Alguns autores têm dado maior ênfase à descrição do uso de recursos pesqueiros, como por exemplo, Hanazaki (2001), que analisou a atual situação das atividades de uso de recursos aquáticos por populações caiçaras do litoral sul de São Paulo; Hanazaki et al. (1996) fizeram um levantamento do uso de recursos na Ponta da Almada (Ubatuba/SP) em particular com o uso de plantas e peixes. Ramires \& Barrella (2001) analisaram a pesca artesanal praticada por pescadores da Estação Ecológica de Juréia Itatins, com respeito à composição, sazonalidade e produtividade dos recursos pesqueiros utilizados. Thé (2002), analisou a atividade pesqueira de duas comunidades de pescadores do Rio São Francisco (MG) e verificou a existência de regras de controle de acesso e tempo de utilização dos pesqueiros, o que interfere diretamente na exploração e conservação dos recursos.

Outros trabalhos dão ênfase a aspectos ecológicos e comportamentais dos peixes. Silvano \& Begossi (2002), verificaram o conhecimento dos pescadores do Rio Piracicaba sobre biologia e comportamento dos peixes. Souza \& Barrella (2001) e Ramires \& Barrella (no prelo) analisaram o conhecimento dos pescadores artesanais da Estação Ecológica de Juréia Itatins em relação ao habitat, ecologia trófica e distribuição espacial dos peixes e compararam o etnoconhecimento da população local com a literatura científica; Costa Neto \& Marques (2000a) descreveram a percepção dos pescadores de Siribinha (BA) sobre o comportamento através da produção de som, reprodução e ecologia trófica. Os mesmo autores (Costa Neto \& Marques, 2000b) observaram o conhecimento dos pescadores relacionado à distribuição temporal e espacial dos recursos pesqueiros na Bahia. Clauzet (2000), relacionou o conhecimento dos pescadores de Enseada do Mar Virado, em Ubatuba (SP), sobre variáveis ambientais com os resultados de produção pesqueira da comunidade. Cardoso et al. (2002), verificaram o conhecimento local e a prática da pesca da manjuba desenvolvida por duas 
comunidades de pescadores de Ilha do Cardoso (SP). Fernandes-Pinto (2002) resgatou, registrou e analisou o conhecimento ecológico local dos pescadores da Barra do Superagüi (PR) sobre os peixes, com ênfase em aspectos da ecologia trófica das espécies.

O presente trabalho pode ser caracterizado como um estudo etnoictiológico, no entanto salienta-se a contribuição da etnoecologia na análise das interações ecológicas entre os pescadores e os peixes e na análise do conhecimento tradicional originado e empregado no cotidiano dos pescadores sobre as interações ecológicas que os peixes apresentam nos ecossistemas explorados por eles, através da pesca artesanal.

\section{Considerações sobre o Etnoconhecimento Caiçara}

O conhecimento sobre a pesca em particular e toda a cultura caiçara em geral é transmitido através de experiências do cotidiano e através do relacionamento entre os membros das comunidades. De acordo com Marques (1991), a aquisição de informações sobre o meio ambiente e seus recursos, bem como o modo de como lidar com eles, estabelece-se através de uma transmissão cultural. Paz \& Begossi (1996), também afirmam que o conhecimento dos pescadores é proveniente do cotidiano, de experiências vividas e compartilhadas de geração a geração.

Todo o conhecimento local demonstrado pelas comunidades caiçaras do litoral paulista é amplo e tem influência direta no êxito da atividade pesqueira desenvolvida por elas, além de fazer parte dos traços culturais caiçaras. A existência e continuidade do conhecimento local são fundamentais para a conservação da biodiversidade nos ambientes litorâneos. Segundo Costa-Neto \& Marques (2000c), o conjunto de conhecimentos teórico-práticos que os pescadores apresentam sobre o comportamento, hábitos alimentares, reprodução, taxonomia e ecologia dos peixes, oferece uma rica fonte de informações de como manejar, conservar e utilizar os recursos pesqueiros de maneira sustentável. Para Diegues (1988b), a conservação da diversidade biológica tem que ser concebida em parâmetros mais amplos de conservação da diversidade cultural.

O estudo do conhecimento caiçara é um passo para o reconhecimento da contribuição destas populações para a conservação do ambiente e dos recursos naturais 
por elas utilizados. O conhecimento caiçara pode ser o ponto de partida para novos planos de gestão ambiental que visem conservar tanto a biodiversidade quanto as diferentes culturas brasileiras. Muitos estudos têm sido desenvolvidos nesta área temática, enfocando as relações entre as comunidades tradicionais e os recursos naturais do ambiente, e segundo Clauzet (2002), alguns destes têm proposto que a incorporação do conhecimento destas comunidades é fundamental no desenvolvimento de planos de manejo sustentável. De acordo com Sanches (1992), levantamentos etnobiológicos valorizam o conhecimento caiçara e contribuem para a preservação do patrimônio biológico e cultural da Mata Atlântica. 


\section{OBJETIVOS}

\subsection{Objetivo geral}

Caracterizar a pesca no Vale do Ribeira (SP) enfocando o uso dos recursos pesqueiros por pescadores artesanais e esportivos e o etnoconhecimento caiçara.

\subsection{Objetivos específicos}

1. Analisar a atividade de pesca artesanal desenvolvida por comunidades caiçaras do Vale do Ribeira, em relação aos métodos e pontos de pesca utilizados, sazonalidade e espécies de peixes capturadas, bem como as condições ambientais que influenciam a atividade pesqueira, segundo o conhecimento dos pescadores artesanais, e ainda, suas relações com outras atividades econômicas.

2. Realizar um estudo etnoictiológico, enfocando em especial, aspectos de etnoecologia, para obter informações sobre a diversidade da ictiofauna marinha através do conhecimento dos pescadores artesanais, abordando aspectos morfológicos, ecológicos e comportamentais dos peixes, tais como: habitat, alimentação, predação, reprodução, comportamento, entre outros, verificando também as similaridades entre o etnoconhecimento caiçara e a literatura científica.

3. Caracterizar a pesca esportiva praticada nas comunidades caiçaras estudadas, traçar o perfil dos pescadores esportivos, bem como analisar suas relações e possíveis influências no modo de vida dos pescadores artesanais. 


\section{METODOLOGIA}

\section{1 Área de Estudo}

Como área de estudo deste trabalho foram demarcados os municípios de Iguape, Cananéia e Ilha Comprida, pertencentes ao Vale do Ribeira, localizado ao sul do estado de São Paulo (Figura 1).

O Vale do Ribeira compreende a bacia hidrográfica do rio Ribeira de Iguape. Abrange uma área de aproximadamente $16.528 \mathrm{~km}^{2}$, com 23 municípios, totalizando cerca de 300 mil habitantes. Essa região caracteriza-se por apresentar um dos mais baixos índices sócio-econômicos do estado, com altas taxas de mortalidade infantil e analfabetismo. A falta de regularização fundiária aparece como um dos mais sérios problemas para a região. A economia local é baseada na bananicultura, na teicultura (chá preto), na pesca artesanal e industrial, no turismo e na agroindústria. A questão ambiental também assume grande importância nesta área, que se caracteriza por apresentar uma cobertura vegetal nativa ainda bastante significativa, abrigando a maior parte de remanescentes de Mata Atlântica do Estado (São Paulo, 1990).

Apesar de o Vale do Ribeira ser uma das poucas áreas remanescentes de Mata Atlântica no Estado de São Paulo, nas últimas décadas a mata vem sendo largamente substituída pela agricultura e pela pecuária. No entanto, a forma como tais atividades são conduzidas resulta em baixa produtividade e numa possibilidade de comércio muito instável (São Paulo, 1992).

Na porção litorânea do Vale do Ribeira está a região lagunar-estuarina de Iguape-Cananéia-Paranaguá que representa uma área de aproximadamente $5800 \mathrm{~km}^{2}$, localizada entre os Estados de São Paulo e Paraná. Trata-se de um ecossistema bastante complexo, que abrange um conjunto de lagunas, braços de mar, baías, estuários, restingas, ilhas e morros isolados. Destaca-se na região estudada, uma forte atividade 
pesqueira, onde a manjuba, o robalo, a tainha e o camarão se caracterizam como as principais espécies capturadas (São Paulo, 1992; 1998a).

A Bacia do Rio Ribeira do Iguape abrange exatamente as regiões Sul-Sudeste

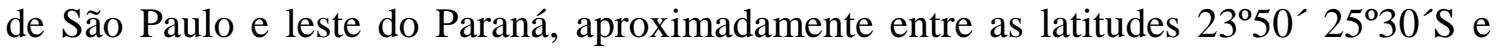
longitudes $46^{\circ} 50^{\prime}$ e $50^{\circ} 00^{\prime} \mathrm{W}$. Tendo sua nascente na Serra de Paranapiacaba, o Rio Ribeira se estende por 470 km, parte no Paraná e parte em São Paulo. Alcança o Oceano Atlântico no município de Iguape (SP), mais precisamente num local denominado Barra do Ribeira (São Paulo, 1991; 1998b).

De um modo geral, o clima da Bacia do Rio Ribeira de Iguape e do Litoral Sul pode ser classificado como tropical úmido, com ligeira variação entre as zonas costeiras e o alto da Serra de Paranapiacaba, sempre com alto índice pluviométrico (Sanches, 1997).

\section{As Comunidades Caiçaras}

Como mencionado anteriormente, este trabalho fez parte de um projeto temático de pesquisa (Os Peixes e a Pesca no Sul de São Paulo, Biota/Fapesp), onde foram visitadas diversas comunidades caiçaras, de diversos municípios do Vale do Ribeira. A partir da participação nos trabalhos de campo do referido projeto temático e com base nos dados obtidos, optou-se, para esta pesquisa, estudar algumas comunidades de pescadores dos municípios de Iguape, Cananéia e Ilha Comprida, (Figura 1) onde a pesca artesanal é uma das atividades econômicas principais e que apresentam um contato com a pesca esportiva e o turismo de forma geral.

Dessa forma as comunidades estudadas foram as seguintes:

Iguape: Barra do Ribeira e Jairê

Cananéia: Carijo e Porto Cubatão

Ilha Comprida: Pedrinhas 


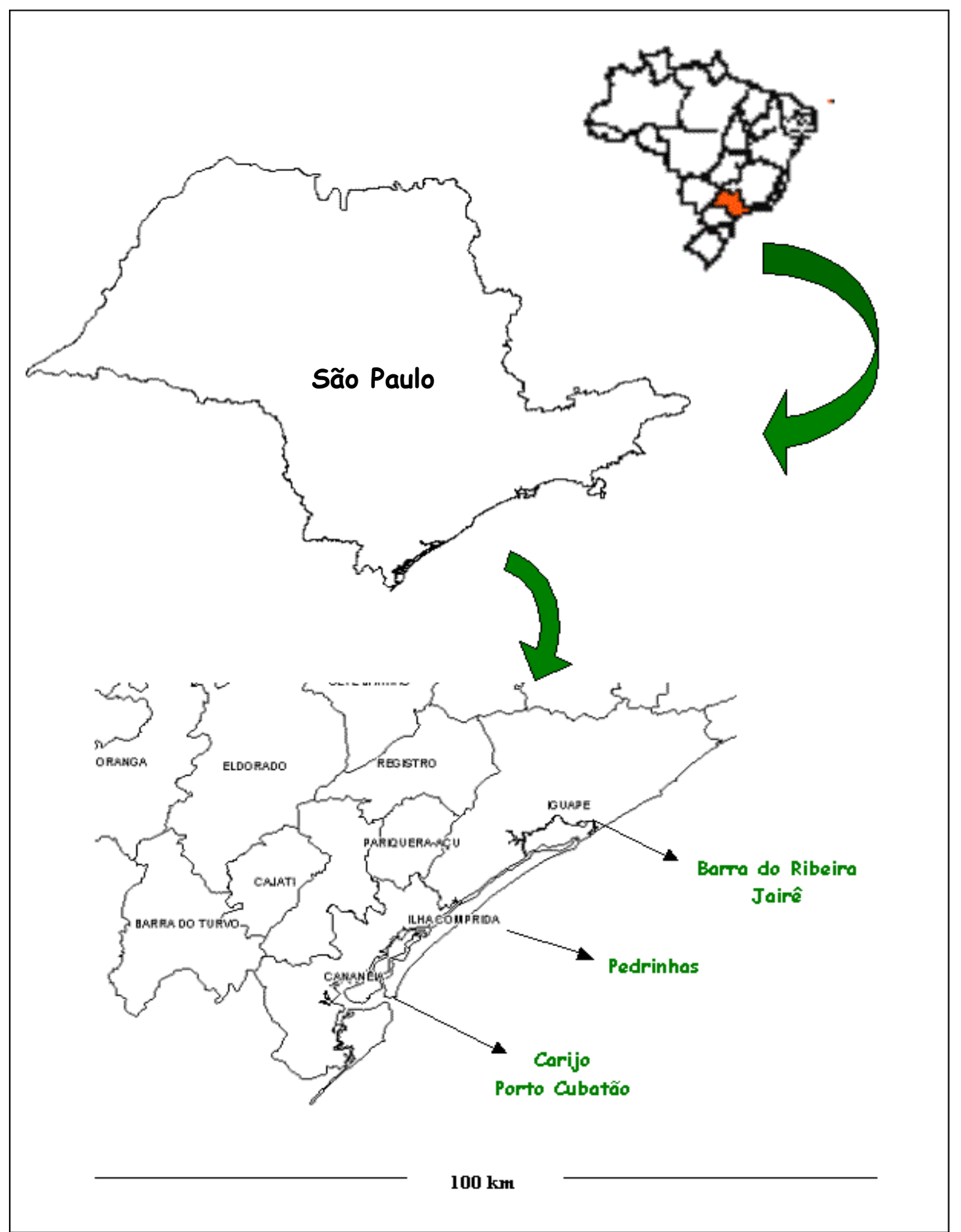

Fonte: Adaptado de Atlas Eletrônico do Estado de São Paulo (www.eatlas.sp.gov.br/mappage.asp).

Figura 1- Área de estudo. Municípios de Iguape, Cananéia e Ilha Comprida, com destaque para as comunidades caiçaras estudadas 


\subsection{Materiais e Métodos}

Este trabalho iniciou-se em agosto de 2001 com a realização de visitas preliminares para o reconhecimento de algumas comunidades caiçaras dos municípios estudados. A coleta de dados foi realizada no período de janeiro de 2002 a agosto de 2003, onde diversas viagens de campo foram realizadas em diferentes épocas do ano. Os dados foram coletados seguindo 3 etapas: 1) coleta de dados sobre a pesca artesanal, 2) levantamento etnoictiológico e 3) coleta de dados sobre a pesca esportiva. Em algumas viagens de campo as etapas 1 e 3 puderam ser realizadas simultaneamente. Além disso, foram realizadas observações diretas sobre a atividade pesqueira artesanal e esportiva, bem como a coleta de material biológico.

\section{Entrevistas}

A principal técnica de coleta de dados utilizada neste trabalho foi a entrevista. Ela permite a captação imediata e corrente da informação desejada, praticamente com qualquer tipo de informante, sobre os mais variados tópicos (Ludke \& André, 1986). Através de entrevistas, o pesquisador busca obter informações contidas na fala dos informantes, permitindo um aprofundamento do assunto abordado. Com a entrevista aberta ou não-estruturada, pode-se trabalhar de modo com que o informante possa abordar livremente o tema proposto. Com as entrevistas estruturadas pressupõem-se perguntas previamente formuladas (Cruz Neto, 1994; Mergulhão \& Vasaki, 1998).

O tipo de entrevista realizada foi a semi-estruturada, onde constavam tanto questões abertas como fechadas permitindo a coleta de informações de diversas naturezas.

\section{Coleta de Dados sobre a Pesca Artesanal}

Primeiramente foram realizadas entrevistas preliminares com os pescadores artesanais, maiores de 18 anos, residentes nas comunidades caiçaras visitadas. Estas entrevistas (anexo A) abordaram aspectos gerais da pesca, informações sócioeconômicas, tempo de pesca, tecnologia e estratégias de pesca utilizadas, dentre outros. Utilizou-se o método de “bola de neve” (Bailey, 1982), no qual ao chegar a comunidade 
procurou-se por pessoas que tivessem contato direto com a atividade de pesca. Ao final de cada entrevista era solicitado ao informante que indicasse um ou mais pescadores da comunidade que tivesse a pesca artesanal como uma das principais fontes de renda.

\section{Levantamento Etnoictiológico}

Após a obtenção das informações sócio-econômicas foram definidos os pescadores que fariam parte do levantamento etnoictiológico. Nesta fase do trabalho foram entrevistados os pescadores que possuíam maior conhecimento sobre a atividade de pesca e os peixes da região. Os critérios para a definição dos informantes foram: 1) tempo de pesca igual ou superior a 10 anos; 2) dedicação integral à atividade de pesca; 3) pescadores aposentados, que ainda pescam para consumo ou eventual comércio; 4) pescadores que desenvolvem outras atividades ligadas à pesca (guias de pesca esportiva, coletores de iscas naturais, etc.); 5) caseiros, ex-pescadores com 10 ou mais anos de pesca. Definidos os informantes, estes foram entrevistados com o auxílio de questionários semi-estruturados que abordavam questões sobre a descrição dos peixes (diferenças entre jovens e adultos e entre machos e fêmeas), o hábitat (distribuição vertical e horizontal), a alimentação (dieta e predação), as técnicas para captura, a sazonalidade (época de maior captura), a reprodução e as etnoespécies (anexo B).

\section{Coleta de Dados sobre a Pesca Esportiva}

Foram realizadas entrevistas com pescadores esportivos que visitavam o Vale do Ribeira para a prática da pesca esportiva, através de questionários estruturados (anexo C), onde foram coletados dados gerais sobre o informante (idade, sexo, grau de instrução, profissão), se possuíam documentos de pesca, se possuíam propriedade na região, a localidade do informante e a freqüência das pescarias. Estes dados proporcionaram a descrição do perfil dos pescadores. Foram informados também o número de pescadores do grupo, o tipo de hospedagem que mais utilizavam, se contratavam, compravam ou alugavam algo na região (piloto, barcos, cozinheiro, mantimentos, iscas, etc.), os tipos de aparelhos utilizados, as espécies mais procuradas, o local, a época e o modo como estas espécies eram capturadas. Por fim, também foi 
questionada a opinião do informante sobre a qualidade do local para a prática da pesca esportiva e se a qualidade melhorou ou piorou em relação aos anos anteriores.

As entrevistas foram realizadas nos locais e momentos em que os pescadores esportivos eram encontrados praticando a pesca esportiva. Dessa forma, foram entrevistados todos os grupos de pescadores esportivos encontrados nas comunidades, durante os períodos de coleta de dados.

\section{Observações Diretas}

Observações diretas foram realizadas como forma de complementar a coleta de dados, bem como conversas informais também forneceram informações relevantes. Para isso fez-se muito importante o diário de campo, no qual foram anotadas as informações resultantes das observações realizadas e também das conversas informais. Segundo Viertler (2002), na pesquisa social antropológica torna-se indispensável o uso de um diário de campo em que são anotadas desde as observações feitas até as impressões subjetivas tidas pelo pesquisador com relação aos fatos ocorridos na comunidade em que se desenvolve o trabalho.

Alguns autores como Cruz Neto (1994) e Lukde \& André (1986) apontam a importância de técnicas de observação como estratégia para a captação de uma variedade de situações ou fenômenos que não são obtidos por meio de perguntas, uma vez que, observados diretamente, podem transmitir fielmente a realidade estudada. Essa técnica se realiza através do contato direto do pesquisador com o fenômeno observado para obter informações sobre a realidade dos informantes em seu próprio contexto.

\section{Coleta de Material Biológico}

Foi elaborada uma coleção zoológica com exemplares que representam as espécies mais capturadas pelos pescadores artesanais da região. Os espécimes coletados foram fixados em formol $10 \%$ e em seguida armazenados em álcool 70 GL. A identificação foi feita inicialmente pela pesquisadora responsável pelo presente trabalho e depois revisada pelo Dr. Walter Barrella (PUC-SP). 


\section{RESULTADOS E DISCUSSÃO}

\subsection{Pesca Artesanal e as Populações Caiçaras}

A presente pesquisa abrangeu a pesca artesanal em 3 municípios do Vale do Ribeira, totalizando 110 entrevistas com pescadores de 5 comunidades caiçaras, sendo que, 43 foram realizadas na comunidade da Barra do Ribeira (Iguape), 15 no Jairê (Iguape), 17 no Carijo (Cananéia), 19 em Porto Cubatão (Cananéia) e 16 em Pedrinhas (Ilha Comprida).

\section{Os Pescadores, a Importância da Pesca Artesanal e outras Atividades}

A idade média dos pescadores/informantes foi de 43,57 anos na Barra do Ribeira; 55,14 anos no Jairê; 44,76 anos no Carijó; 49,94 anos em Porto Cubatão e 36,26 anos em Pedrinhas. Todos os entrevistados são do sexo masculino e a maioria possui grau de escolaridade referente ao ensino fundamental incompleto (Tabela 1).

A pesca artesanal ainda tem importância total no orçamento familiar, segundo 39,53\% dos pescadores entrevistados na Barra do Ribeira, 66,66\% no Jairê, 88,23\% no Carijo e 57,89\% em Porto Cubatão, enquanto que em Pedrinhas, a pesca artesanal tem importância total apenas para 18,75\% dos entrevistados, embora seja praticada diariamente por 68,75\% dos pescadores. Hanazaki (2001), também aponta que em Pedrinhas a pesca não é mais a principal atividade econômica da população, e é direcionada principalmente para a captura de peixes para o consumo local.

A pesca artesanal também é praticada diariamente pelos pescadores da Barra do Ribeira (67,44\%), Jairê (86.66\%) e Carijo (88,23\%). Os pescadores de Porto Cubatão praticam a pesca semanalmente $(57,89 \%)$ ou quinzenalmente (26,31\%) (Tabela 1$)$.

O tempo de pesca, ou seja, o tempo de trabalho dos pescadores na atividade pesqueira variou de 1 a 80 anos, sendo que as médias foram: 22,77 anos na Barra do 
Ribeira; 30,2 anos no Jairê; 26,65 anos no Carijó; 34 anos em Porto Cubatão e 24,69 anos em Pedrinhas (Tabela 1).

Tabela 1. Perfil sócio econômico dos pescadores artesanais das comunidades caiçaras estudadas.

\begin{tabular}{|c|c|c|c|c|c|}
\hline \multirow[b]{2}{*}{$\begin{array}{l}\text { Características } \\
\text { Estudadas }\end{array}$} & \multicolumn{2}{|c|}{ Iguape } & \multicolumn{2}{|c|}{ Cananéia } & \multirow{2}{*}{$\begin{array}{c}\text { Ilha } \\
\text { Comprida } \\
\text { Pedrinhas } \\
(\mathrm{n}=16)\end{array}$} \\
\hline & $\begin{array}{c}\text { Barra do } \\
\text { Ribeira } \\
(n=43)\end{array}$ & $\begin{array}{c}\text { Jairê } \\
(n=15)\end{array}$ & $\begin{array}{l}\text { Carijo } \\
(n=17)\end{array}$ & $\begin{array}{c}\text { Porto } \\
\text { Cubatão } \\
(n=19)\end{array}$ & \\
\hline \multicolumn{6}{|l|}{ Faixa etária } \\
\hline Média & 43,57 & 55,14 & 44,76 & 49,94 & 36,26 \\
\hline Mínima & 19 & 34 & 26 & 25 & 21 \\
\hline Máxima & 80 & 78 & 64 & 72 & 76 \\
\hline Desvio padrão & 16,41 & 12,01 & 11,24 & 14,28 & 19,71 \\
\hline \multicolumn{6}{|l|}{$\operatorname{Sexo}(\%)$} \\
\hline \multicolumn{6}{|l|}{ Escolaridade (\%) } \\
\hline Fundamental incompleto & 53,49 & 93,33 & 94,12 & 57,89 & 68,75 \\
\hline Fundamental completo & 13,95 & 0 & 0 & 5,26 & 6,25 \\
\hline Médio Incompleto & 6,98 & 0 & 0 & 10,53 & 12,5 \\
\hline Médio Completo & 6,98 & 6,66 & 5,88 & 0 & 6,25 \\
\hline Analfabeto & 6,98 & 0 & 0 & 26,31 & 6,25 \\
\hline \multicolumn{6}{|l|}{ Importância da Pesca (\%) } \\
\hline Total & 39,53 & 66,66 & 88,23 & 57,89 & 18,75 \\
\hline Parcial & 37,21 & 33,33 & 11,76 & 15,79 & 43,75 \\
\hline Pequena & 16,28 & 0 & 0 & 21,05 & 25 \\
\hline \multicolumn{6}{|l|}{ Freqüência de Pesca (\%) } \\
\hline Diária & 67,44 & 86,66 & 88,23 & 15,79 & 68,75 \\
\hline Semanal & 16,28 & 13,33 & 11,76 & 57,89 & 25 \\
\hline Quinzenal & 6,98 & 0 & 0 & 26,31 & 0 \\
\hline \multicolumn{6}{|l|}{ Tempo de pesca (anos) } \\
\hline Média & 22,77 & 30,2 & 26,65 & 34 & 24,69 \\
\hline Mínima & 1 & 10 & 8 & 15 & 10 \\
\hline Máxima & 65 & 51 & 80 & 60 & 38 \\
\hline Desvio padrão & 14,6 & 16,69 & 13,37 & 16,04 & 16,77 \\
\hline
\end{tabular}

A pesca artesanal antes desenvolvida como forma de subsistência, hoje já não é mais a única atividade econômica das comunidades litorâneas. Segundo Hanazaki (2001), atividades tradicionalmente praticadas pelos caiçaras, como a pesca e a agricultura, passam a ter importância secundária conforme as atividades ligadas ao turismo tendem a crescer. Dessa forma, a atividade pesqueira como provedora de 
recursos diretos para a alimentação local, passa a ocupar uma posição periférica quando comparada à pesca direcionada para o turismo.

Os pescadores também desenvolvem outras atividades para complementar a renda familiar. Dentre estas atividades as principais também estão relacionadas ao turismo, como comércio (restaurantes, pousadas, bares), prestação de serviços em casas de veraneio, aluguel de barcos para passeios e para a pesca esportiva, comércio de iscas naturais, entre outras (Tabela 2).

Tabela 2. Outras atividades econômicas desenvolvidas pelos pescadores artesanais de Iguape, Cananéia e Ilha Comprida (os valores correspondem a \% de citação nas entrevistas)

\begin{tabular}{lccccc}
\hline $\begin{array}{l}\text { Comunidades } \\
\text { Atividades }\end{array}$ & $\begin{array}{c}\text { Barra do } \\
\mathbf{R} \text { ibeira } \\
(\mathbf{n = 4 3 )}\end{array}$ & $\begin{array}{c}\text { Jairê } \\
(\mathbf{n = 1 5 )}\end{array}$ & $\begin{array}{c}\text { Carijo } \\
(\mathbf{n}=\mathbf{1 7})\end{array}$ & $\begin{array}{c}\text { Porto } \\
\text { Cubatão } \\
(\mathbf{n}=\mathbf{1 9})\end{array}$ & $\begin{array}{c}\text { Pedrinhas } \\
(\mathbf{n = 1 6 )}\end{array}$ \\
\hline Agricultor & - & 26,66 & - & - & - \\
Aposentado & - & 6,66 & - & 15,79 & 12,5 \\
Caseiro & 2,32 & 6,66 & - & 10,73 & 25 \\
Comércio & 6,98 & 20 & - & - & 18,75 \\
Comércio de iscas naturais & 11,63 & - & - & 15,79 & 50 \\
Educador ambiental & - & - & - & - & 6,25 \\
Funcionário público & 11,63 & - & - & 5,26 & - \\
Jardineiro & 2,32 & - & - & - & - \\
Marceneiro & 4,65 & - & - & - & - \\
Motorista & 2,32 & - & - & - & - \\
Pedreiro & 18,6 & - & - & - & 12,5 \\
Piloteiro & - & - & 5,88 & 31,58 & 75 \\
Pintor & - & - & - & 5,26 & 12,5 \\
Redeiro & - & - & 11,76 & - & 12,5 \\
Segurança & 2,32 & - & - & - & - \\
\hline
\end{tabular}

Em algumas comunidades caiçaras de outras regiões, a pesca artesanal ainda é desenvolvida como principal fonte de renda, como por exemplo, nas comunidades do Parque Estadual de Ilhabela (SP), onde Maldonado (1997), aponta que a pesca, além de ser a principal fonte de renda, é também em $80 \%$ dos casos, praticada como forma de subsistência. A pesca artesanal também foi apontada como a principal atividade econômica da comunidade de Marituba do Peixe, no Rio São Francisco (Silva et al., 1990). 
Mesmo desenvolvendo outras atividades, as comunidades caiçaras ainda mantêm um relacionamento complexo com o ambiente natural, que não é marcado somente por instâncias econômicas. Valores, tradições, crenças religiosas e percepções permanecem na cultura caiçara e exercem um papel fundamental no cotidiano destas comunidades (Diegues, 1988b), principalmente na maneira como a pesca artesanal é desenvolvida no Litoral Sul e Vale do Ribeira (Estado de São Paulo), onde acaba por caracterizar a forma com que os pescadores manejam os estoques pesqueiros.

\section{As Espécies Capturadas}

A diversidade de espécies potencialmente exploráveis pela pesca artesanal dos municípios da região litorânea do Vale do Ribeira é grande, porém algumas espécies são mais capturadas e mais comercializadas do que outras. Alguns estudos sobre a pesca artesanal nesta região apontam a diversidade de peixes explorada pelos pescadores artesanais, como por exemplo, Diegues (2002) que num inventário feito sobre as áreas úmidas brasileiras, apontou que a ictiofauna do complexo estuarino lagunar de IguapeCananéia-Paranaguá é representada pelas espécies do gênero Mugil sp. (tainhas e paratis), Centropomus sp. (robalos), Cynoscion sp. (pescadas), Micropogonias furnieri (corvina), Scomberomus maculatus (sororoca), Arius sp. (bagres), Anchoviella sp. (manjuba), dentre outras. A Tabela 3 mostra as principais espécies citadas pelos pescadores entrevistados, como as que são freqüentemente capturadas e comercializadas.

Tabela 3. Espécies de peixes de maior importância para a pesca artesanal (\% de citações nas entrevistas)

\begin{tabular}{lccccc}
\hline \multirow{2}{*}{ Espécies } & \multicolumn{2}{c}{ Iguape } & \multicolumn{2}{c}{ Cananéia } & $\begin{array}{c}\text { Ilha } \\
\text { Comprida }\end{array}$ \\
\cline { 2 - 6 } & $\begin{array}{c}\text { Barra do } \\
\text { Ribeira } \\
(\mathbf{n = 4 3 )}\end{array}$ & $\begin{array}{c}\text { Jairê } \\
(\mathbf{n}=\mathbf{1 5})\end{array}$ & $\begin{array}{c}\text { Carijo } \\
(\mathbf{n = 1 7 )}\end{array}$ & $\begin{array}{c}\text { Porto } \\
\text { Cubatão } \\
(\mathbf{n = 1 9 )}\end{array}$ & $\begin{array}{c}\text { Pedrinhas } \\
(\mathbf{n = 1 6 )}\end{array}$ \\
\hline Bagre (Ariidae) & 11,63 & 26,66 & 23,53 & 36,84 & 43,75 \\
Corvina (Micropogonias furnieri) & 11,63 & 0 & 52,94 & 26,31 & 31,25 \\
Manjuba (Anchioviella lepidentostole) & 69,77 & 100 & 0 & 0 & 0 \\
Parati (Mugil sp.) & 13,95 & 0 & 35,29 & 47,37 & 31,25 \\
Pescada (Cynoscion sp.) & 6,98 & 0 & 35,29 & 36,84 & 62,5 \\
Robalo (Centropomus sp.) & 65,12 & 33,33 & 29,41 & 57,89 & 81,25 \\
Sardinha (Anchovia clupeiodes) & 30,23 & 13,33 & 0 & 0 & 0 \\
Sororoca (Scomberomorus brasiliensis) & 0 & 0 & 58,82 & 10,53 & 0 \\
Tainha (Mugil sp.) & 88,37 & 0 & 58,82 & 57,89 & 81,25 \\
\hline
\end{tabular}


O bagre (Ariidae) foi citado em todas as comunidades, no entanto, com porcentagens de citação inferiores a de outras espécies, como por exemplo o robalo (Centropomus sp.) que foi a principal espécie citada em Pedrinhas e Porto Cubatão. A tainha (Mugil sp.), também foi muito citada pelos pescadores da Barra do Ribeira (88,37\%), Carijo (58,82\%), Porto Cubatão (57,89\%) e Pedrinhas (81,25\%). Além delas, foram citadas a corvina (Micropogonias furnieri), a manjuba (Anchioviella lepidentostole), o parati (Mugil sp.), a pescada (Cynoscion sp.), a sardinha (Anchovia clupeiodes) e a sororoca (Scomberomorus brasiliensis). A diferença na diversidade de espécies citadas pelos pescadores está relacionada com os diferentes métodos de pesca utilizados, os diferentes tipos de ambientes explorados e as diferentes épocas do ano.

Nas comunidades de Iguape (Barra do Ribeira e Jairê), a manjuba (Anchioviella lepidentostole) foi apontada pelos pescadores como uma espécie muito importante para a pesca artesanal. Foi citada por $69,77 \%$ dos pescadores da Barra do Ribeira e por $100 \%$ dos pescadores do Jairê. Em estudo anterior realizado por Ramires et al. (2002), a manjuba também apareceu como uma espécie importante, em que foi citada por 50\% dos pescadores. Neste estudo ainda, os autores observaram que 50\% dos pescadores capturavam a manjuba na Barra do Rio Ribeira de Iguape, enquanto que $25 \%$ a capturavam ao longo do Rio Ribeira e outros $25 \%$ a capturavam no mar e que a melhor época de captura citada foi o verão (73,9\%).

Bendazoli \& Rossi-Wongtschowski (1990), num estudo detalhado sobre a manjuba, apontaram que dentro da atividade pesqueira artesanal do litoral sul de São Paulo, a pesca da manjuba em Iguape era sem duvida, da maior importância. Essa atividade envolvia cerca de 2 mil pescadores e oito indústrias de salga no município. Segundo estes autores, as comunidades pesqueiras mais próximas dos locais onde se realiza a pesca da manjuba são a Barra de Icapara e a Barra do Ribeira e é nestas comunidades que se desenvolve a maior parte da pesca comercial. No entanto, a maioria dos pescadores envolvidos nessa atividade vem de bairros próximos ao centro de Iguape, distantes cerca de $25 \mathrm{~km}$ do local, trazidos por caminhões das indústrias para pescarem durante o dia inteiro, retornando apenas à noite para o seu domicílio. A pesca da manjuba 
nestas comunidades se diferencia das demais por se localizar na zona de influência marinha (Bendazoli \& Rossi-Wongtschowski, 1990).

No Jairê, a pesca da manjuba também tem características comerciais, pois sua captura aumenta a ponto de permitir, além da parte retirada para consumo próprio, a salga e a venda do produto fresco. Existem nesta comunidade muitas canoas e redes apropriadas em cada agrupamento de casas (Bendazoli \& Rossi-Wongtschowski, 1990).

\section{Os Métodos de Pesca}

Em relação aos métodos de pesca, a rede de espera foi o único método citado em todas as comunidades. Este método é utilizado por $58,14 \%$ dos pescadores da Barra do Ribeira, por 26,66\% dos pescadores do Jairê, no Carijo por 76,47\%, em Porto Cubatão por $73,68 \%$ e em Pedrinhas por $68,75 \%$ dos pescadores. Além da rede de espera, os pescadores citaram outros métodos, resultando em 11 métodos na Barra do Ribeira, 10 métodos em Pedrinhas, 7 em Porto Cubatão e 5 no Jairê e Carijo, conforme mostra a Tabela 4.

Tabela 4. Métodos de pesca utilizados pelos pescadores artesanais

\begin{tabular}{|c|c|c|c|c|c|c|c|c|c|c|}
\hline \multirow{3}{*}{ Métodos } & \multicolumn{4}{|c|}{ Iguape } & \multicolumn{4}{|c|}{ Cananéia } & \multirow{2}{*}{\multicolumn{2}{|c|}{$\begin{array}{c}\text { Ilha Comprida } \\
\text { Pedrinhas } \\
(n=16)\end{array}$}} \\
\hline & \multicolumn{2}{|c|}{$\begin{array}{c}\text { Barra do } \\
\text { Ribeira } \\
(n=43)\end{array}$} & \multicolumn{2}{|c|}{$\begin{array}{l}\text { Jairê } \\
(n=15)\end{array}$} & \multicolumn{2}{|c|}{$\begin{array}{l}\text { Carijo } \\
(n=17)\end{array}$} & \multicolumn{2}{|c|}{$\begin{array}{l}\text { Porto Cubatão } \\
\qquad(\mathrm{n}=19)\end{array}$} & & \\
\hline & $\mathbf{n}$ & $\%$ & $\mathbf{n}$ & $\%$ & $\mathbf{n}$ & $\%$ & $\mathbf{n}$ & $\%$ & $\mathbf{n}$ & $\%$ \\
\hline Arrasto & 4 & 9,3 & 9 & 60 & 6 & 35,29 & 0 & 0 & 2 & 12,5 \\
\hline Caceio & 5 & 11,63 & 0 & 0 & 1 & 5,88 & 0 & 0 & 2 & 12,5 \\
\hline Cerco fixo & 1 & 2,32 & 0 & 0 & 4 & 23,53 & 1 & 5,26 & 3 & 18,75 \\
\hline Corrico & 17 & 39,53 & 13 & 86,66 & 0 & 0 & 0 & 0 & 2 & 12,5 \\
\hline Covo & 0 & 0 & 1 & 6,66 & 0 & 0 & 0 & 0 & 0 & 0 \\
\hline Espinhel & 0 & 0 & 0 & 0 & 0 & 0 & 3 & 15,79 & 1 & 6,25 \\
\hline Gerival & 1 & 2,32 & 0 & 0 & 0 & 0 & 0 & 0 & 1 & 6,25 \\
\hline Lanço & 2 & 4,65 & 0 & 0 & 2 & 11,76 & 2 & 10,53 & 3 & 18,75 \\
\hline Linha de mão & 1 & 2,32 & 0 & 0 & 0 & 0 & 1 & 5,26 & 2 & 12,5 \\
\hline Picaré & 2 & 4,65 & 0 & 0 & 0 & 0 & 0 & 0 & 0 & 0 \\
\hline Rede de espera & 25 & 58,14 & 4 & 26,66 & 13 & 76,47 & 14 & 73,68 & 11 & 68,75 \\
\hline Tarrafa & 8 & 18,6 & 0 & 0 & 0 & 0 & 2 & 10,53 & 0 & 0 \\
\hline Vara & 7 & 16,28 & 1 & 6,66 & 0 & 0 & 6 & 31,58 & 3 & 18,75 \\
\hline
\end{tabular}

A rede de espera, também chamada malhadeira, foi o principal método utilizado pelos pescadores das comunidades do Rio Piracicaba estudadas por Begossi et al. (1997). 
Em outras comunidades caiçaras, a rede de espera também é o método mais utilizado, como mencionado na comunidade da Ponta do Almada em Ubatuba (SP), por Hanazaki (1995), ao contrário do que acontece na comunidade de Mamanguá (RJ) onde Diegues \& Nogara (1999) relatam o uso da rede de espera por apenas 8,3 \% dos pescadores.

Hanazaki (2001) analisou a pesca praticada por comunidades pesqueiras da região em estudo e verificou que as tecnologias ou apetrechos de pesca utilizados diferem de acordo com os objetivos da pesca (direcionada à subsistência ou para a comercialização) e com as espécies capturadas. Isto pôde ser notado na comunidade do Jairê, onde a principal espécie capturada é a manjuba (Anchoviella ledidentostole) e o método mais citado (86,66\%) foi o corrico, que corresponde ao método tradicionalmente utilizado para a captura desta espécie (Bendazoli \& Frosch, 1990). No entanto, a manjuba também é uma das principais espécies capturadas na Barra do Ribeira, porém o corrico foi citado por 39,53\% devido ao fato de outros métodos também serem importantes e utilizados para a captura de outras espécies também importantes, como por exemplo, a rede de espera utilizada para captura de diversas espécies.

O gerival foi um método pouco citado (2,32\% na Barra do Ribeira e 6,25\% em Pedrinhas), pois é utilizado para a captura de camarão branco e não de peixes, porém em Pedrinhas é um método importante, pois está relacionado com a atividade de comércio de iscas naturais que será discutido mais adiante.

\section{Os Pontos de Pesca}

Em Iguape os principais pesqueiros utilizados são a Barra do Rio Ribeira de Iguape e o próprio Rio Ribeira de Iguape. Em Cananéia os principais pesqueiros são o Mar e o canal ${ }^{7}$, também chamado de mar pequeno. Enquanto que na Ilha Comprida, o principal local de pesca também é o canal (Tabela 5).

\footnotetext{
${ }^{7}$ Canal é uma das denominações dadas pelos pescadores e demais moradores da região para a região do Complexo Estuarino Lagunar de Iguape-Cananéia-Ilha Comprida.
} 
Tabela 5. Pontos de pesca utilizados pelos pescadores artesanais

\begin{tabular}{|c|c|c|c|c|}
\hline \multicolumn{2}{|c|}{ Municípios/ Comunidades } & Pontos de pesca & $\mathbf{N}$ & $\%$ \\
\hline \multirow[t]{10}{*}{ Iguape } & Barra do Ribeira & Alto mar & 5 & 11,63 \\
\hline & & Barra do Rio Ribeira & 18 & 41,86 \\
\hline & & Barra de Icapara & 5 & 11,63 \\
\hline & & Coroa do Sapo & 1 & 2,32 \\
\hline & & Jejova & 1 & 2,32 \\
\hline & & Aquário & 1 & 2,32 \\
\hline & & Rio Ribeira & 7 & 16,28 \\
\hline & & Rio Suamirim & 2 & 4,65 \\
\hline & Jairê & Rio Ribeira & 15 & 100 \\
\hline & & Barra do Rio Ribeira & 15 & 100 \\
\hline \multirow[t]{7}{*}{ Cananéia } & Carijo & Alto mar & 12 & 70,59 \\
\hline & & Canal & 3 & 17,65 \\
\hline & & Trincheira & 1 & 5,88 \\
\hline & Porto Cubatão & Barra Ararapira & 2 & 10,53 \\
\hline & & Canal & 15 & 78,95 \\
\hline & & Ilha do Cardoso & 1 & 5,26 \\
\hline & & Itapitangui & 1 & 5,26 \\
\hline \multirow[t]{3}{*}{ Ilha Comprida } & Pedrinhas & Praia da Ilha Comprida & 1 & 6,25 \\
\hline & & Canal & 14 & 87,5 \\
\hline & & Mar & 1 & 6,25 \\
\hline
\end{tabular}

Em um estudo realizado por Clauzet (2000) na Enseada do Mar Virado, em Ubatuba, constatou-se que os pescadores utilizam 3 regiões diferentes para armarem suas redes: a baía da Enseada, o entorno de uma ilha próxima (Ilha do Mar Virado) e a região costeira do mar. Segundo essa autora, os métodos de pesca são escolhidos de acordo com os locais de pesca, os quais por sua vez são escolhidos de acordo com as espécies-alvo das pescarias, que variam de acordo com a época do ano.

\section{As Variáveis da Pesca: Lua, Maré e Chuva}

Os pescadores artesanais atribuem o sucesso ou fracasso das atividades pesqueiras a algumas variáveis relativas às condições ambientais como as fases da lua, os níveis da maré e a presença ou ausência de chuva. Estes fatores são importantes nas tomadas de decisão, como por exemplo, os pontos de pesca a serem utilizados, os métodos mais adequados, as espécies-alvo a serem capturadas, dentre outros. Porém, a opinião dos pescadores a respeito destas variáveis diferiu entre as comunidades, além de terem se mostrado muito variadas também em cada comunidade. Dessa maneira, não foi 
possível se estabelecer segundo a opinião deles se há uma fase da lua que realmente pode aumentar a produtividade da pescarias.

A Figura 2 mostra a diversidade de opiniões dos pescadores sobre a influência das fases da lua no aumento da produtividade pesqueira.

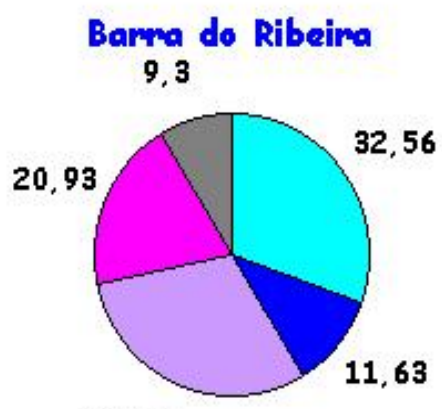

32,56

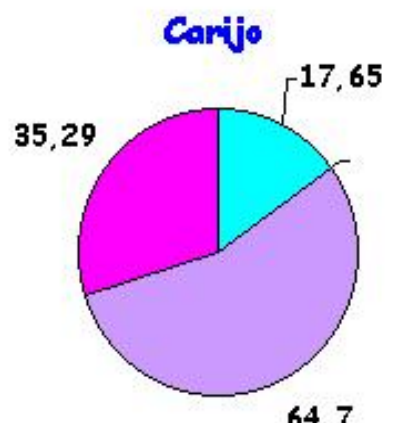

64,7

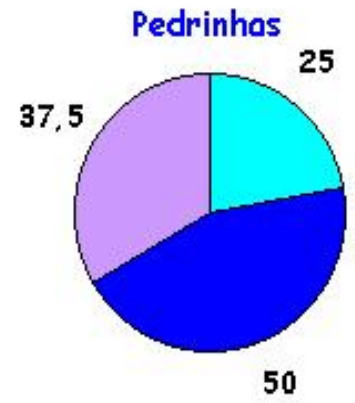

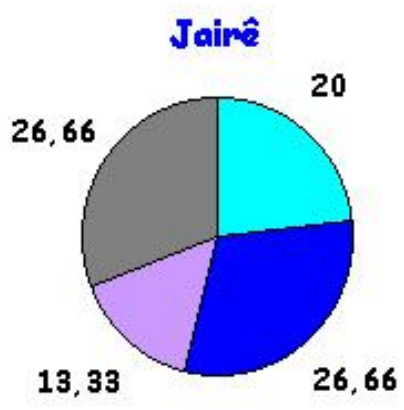

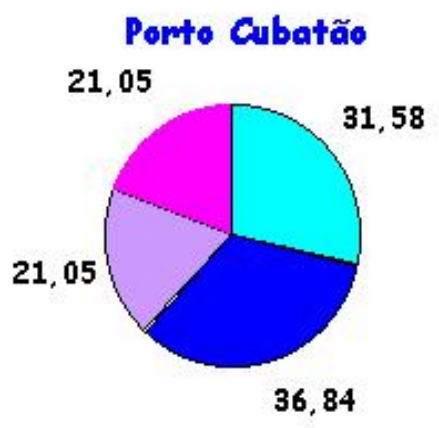

Legenda:

Crescente

Minguante

Nova

Cheia

Nã。 influi

Figura 2 - Opinião dos pescadores sobre a influência das fases da lua no aumento da produtividade pesqueira (\% de citação nas entrevistas) 
Embora as opiniões tenham se mostrado variadas, devido ao fato da pesca, nestas comunidades, ser direcionada para a captura de diferentes espécies, com métodos e pontos de pesca diferenciados, estudos sobre produtividade pesqueira realizados através de amostragem de desembarques pesqueiros da pesca artesanal têm mostrado a possível influência das fases da lua. Clauzet (2000) realizou análises da atividade pesqueira relacionada a variáveis ambientais em Ubatuba (SP) e mostrou que os desembarques pesqueiros amostrados renderam mais durante as fases de lua crescente e na maré baixa. No entanto, Ramires \& Barrella (2003) também verificaram, através de análises de Captura por Unidade de Esforço (CPUE), a influência das variáveis chuva, fases da lua e maré no rendimento da pesca de comunidades caiçaras da Estação Ecológica de Juréia Itatins (EEJI) e verificaram que devido ao baixo número de desembarques pesqueiros realizados nas comunidades da EEJI no período analisado ou ao fato dos desembarques amostrados terem sido de baixa produtividade em $\mathrm{kg}$ totais, não foi possível avaliar a influência de tais variáveis.

Segundo os pescadores entrevistados a maré também tem influência na pesca e mais uma vez a opinião dos pescadores mostrou se variada, conforme mostra a Figura 3.

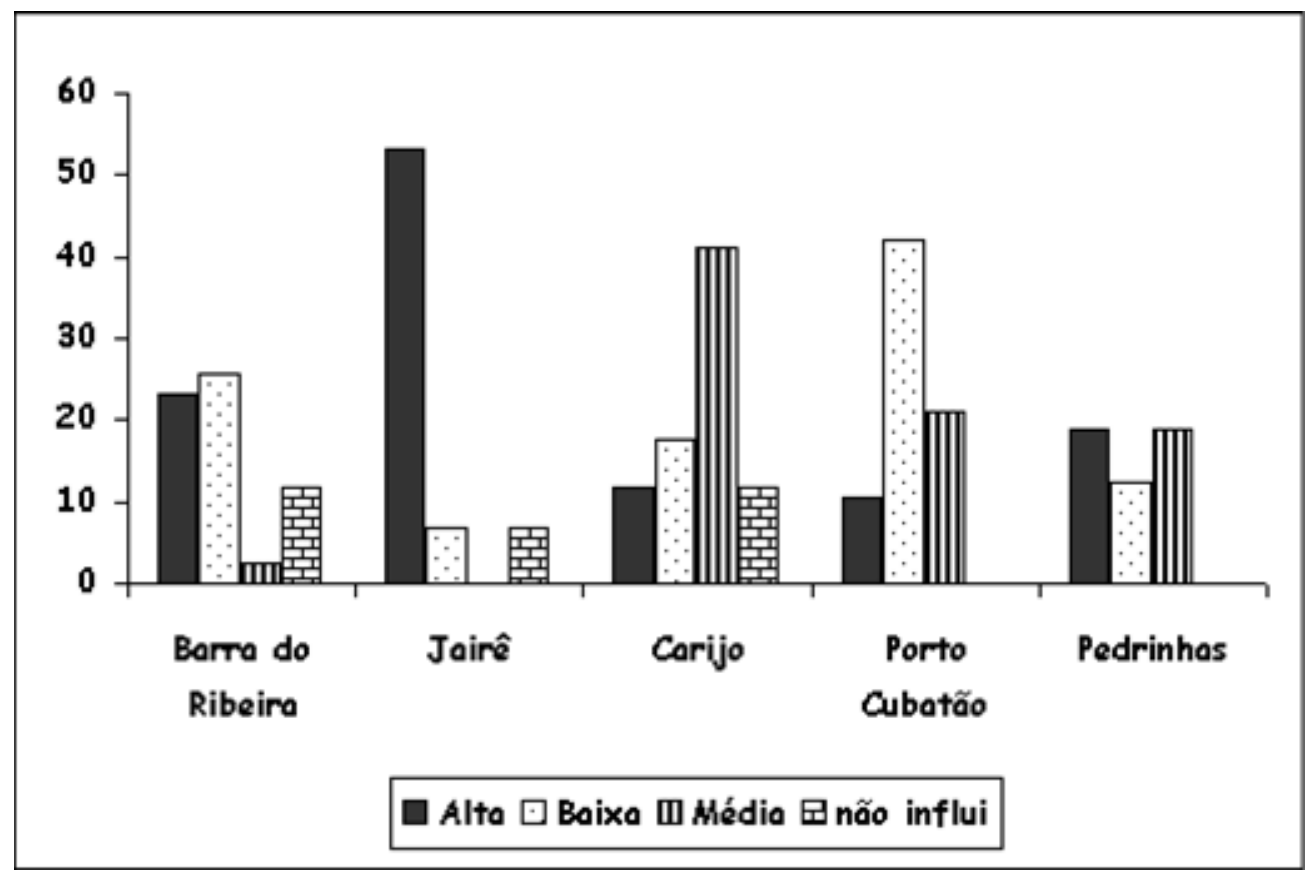

Figura 3 - Opinião dos pescadores artesanais sobre a influência da maré no aumento da produtividade pesqueira (\% de citação nas entrevistas) 
Embora as variáveis fases da lua, presença ou não de chuva e níveis da maré tenham sido tratadas separadamente neste trabalho, pôde-se notar que segundo o conhecimento dos pescadores, estas variáveis podem apresentar relações entre si. Segundo alguns pescadores os níveis da maré podem estar relacionados com a fase da lua, como por exemplo, as marés de quarto e marés de lua, que são marés que influenciam diretamente a produtividade pesqueira. Tais marés foram apenas citadas em entrevistas informais e não puderam ser discutidas e explicadas detalhadamente. No entanto, tal fato pode ser tratado como um indício sobre a complexidade das relações que os pescadores possuem com o ambiente. Sanches (2004) estudou as relações entre os moradores da Estação Ecológica de Juréia Itatins e o ambiente apontando que o uso sistemático e intensivo da Mata Atlântica, feito por estas populações é permeado por fatores materiais, simbólicos, biológicos e culturais. Segundo a autora, tais relações estão condicionadas a vários pressupostos e dentre eles, a presença de calendários ecológicos apropriados para desempenhar atividades de agricultura, caça e pesca. Neste caso, em relação a pesca a autora aponta que o uso de técnicas de captura pode variar de acordo com o calendário lunar.

No trabalho de Ramires \& Barrella (2003), também realizado na Estação Ecológica de Juréia Itatins, os pescadores apontaram a chuva e o vento como fatores modificadores das condições ambientais. As más condições do tempo dificultam o trabalho por tornar o tráfego de embarcações perigoso, uma vez que a chuva e o vento, na maioria das vezes, deixam as barras dos rios e o mar agitados. Tendo em vista o perigo, os pescadores evitam sair com suas embarcações quando está chovendo ou ventando muito. Neste trabalho, os pescadores de todas as comunidades, com exceção de Pedrinhas, preferem pescar na época de seca, conforme mostra a Figura 4. 


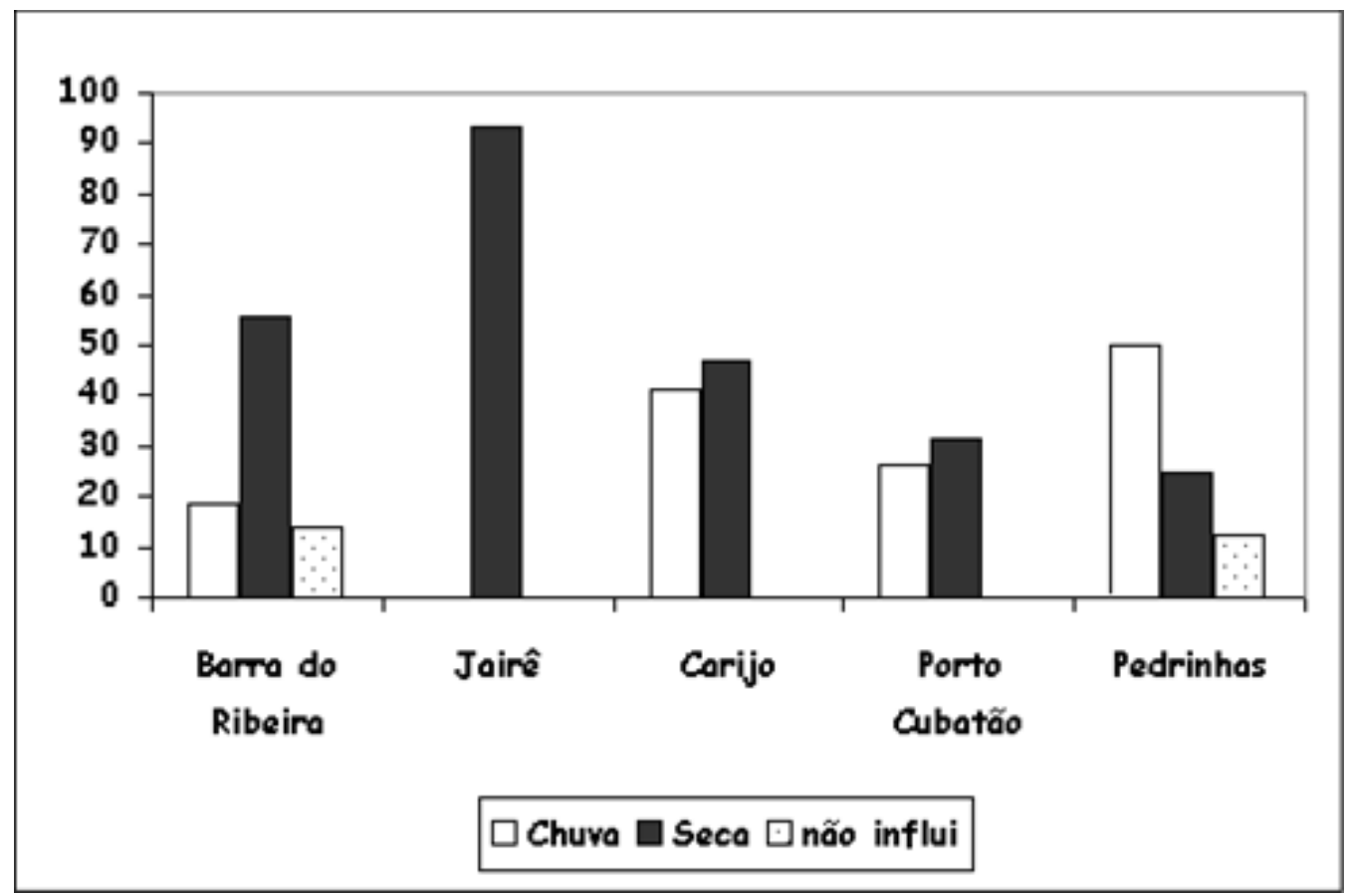

Figura 4 - Opinião dos pescadores artesanais sobre a influência da chuva no aumento da produtividade pesqueira (\% de citação nas entrevistas)

Begossi (1992), em seu trabalho realizado na Ilha de Búzios (SP), mostrou que a chuva não interferiu na atividade pesqueira, enquanto que o vento forte de setembro e outubro foi considerado um fator limitante para a pesca desta comunidade porque as canoas usadas eram pequenas. Nos dias em que o tempo estava ruim devido à atividade do vento, o risco era maior, assim, os entrevistados consideraram que estas variáveis interferiram no rendimento pesqueiro da comunidade estudada em relação ao número de desembarques realizados (Begossi, 1992).

Segundo Costa-Neto \& Marques (2000b), os ciclos lunar e de marés exercem uma influência tanto no comportamento dos peixes quanto no de seus predadores humanos. Na percepção local dos pescadores de Siribinha (BA), um conjunto de termos refere-se às mudanças das correntes, nomeadas como “maré de lançamento”, “maré de quebra” e “maré morta”. Para diagnosticar uma corrente de maré os pescadores prestam atenção no horário de surgimento e desaparecimento da lua. 


\section{A Qualidade dos Pesqueiros}

Os pescadores de cada um dos locais estudados avaliam as condições ambientais para a prática da pesca, observando também a qualidade dos pesqueiros utilizados, a influência da lua e da maré, bem como a influência da chuva na atividade pesqueira. A Figura 5 mostra a opinião dos pescadores sobre a qualidade dos ambientes para a pesca na região.

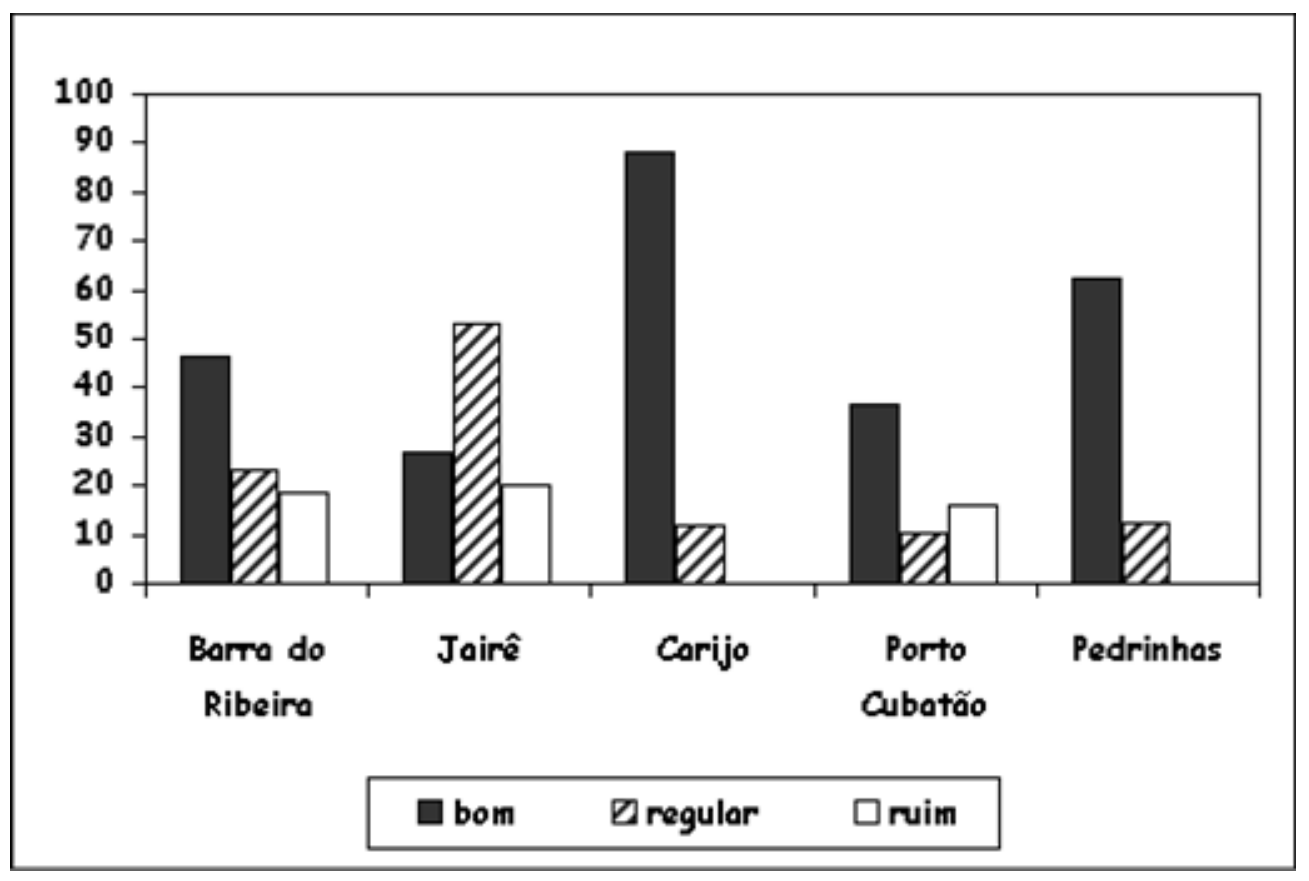

Figura 5 - Opinião dos pescadores artesanais sobre a qualidade dos pontos de pesca da região (\% de citação nas entrevistas)

A maioria dos pescadores avalia que os pesqueiros da região são bons para a pesca, com exceção da comunidade do Jairê, onde a maioria dos pescadores considera a qualidade dos pesqueiros da região regular.

Embora a maioria dos pescadores avalie os pesqueiros da região como "bons pesqueiros” para a pesca artesanal e também associem o sucesso das pescarias às influências de variáveis como maré, lua, chuva, dentre outros, os pescadores tendem a comparar essa atual situação, ou seja, a qualidade dos pesqueiros da região em relação aos anos anteriores. Ao serem questionados sobre a qualidade dos pesqueiros é notável a unanimidade de resposta do tipo: “antigamente era melhor” ou “antes não era assim” ou ainda, “antigamente tinha mais peixe”. 
Em todas as comunidades estudadas, os pescadores concordam com o fato de que a qualidade dos pesqueiros piorou em relação aos anos anteriores. Esta citação chegou até a 100\% na comunidade do Jairê, conforme mostra a Figura 6.

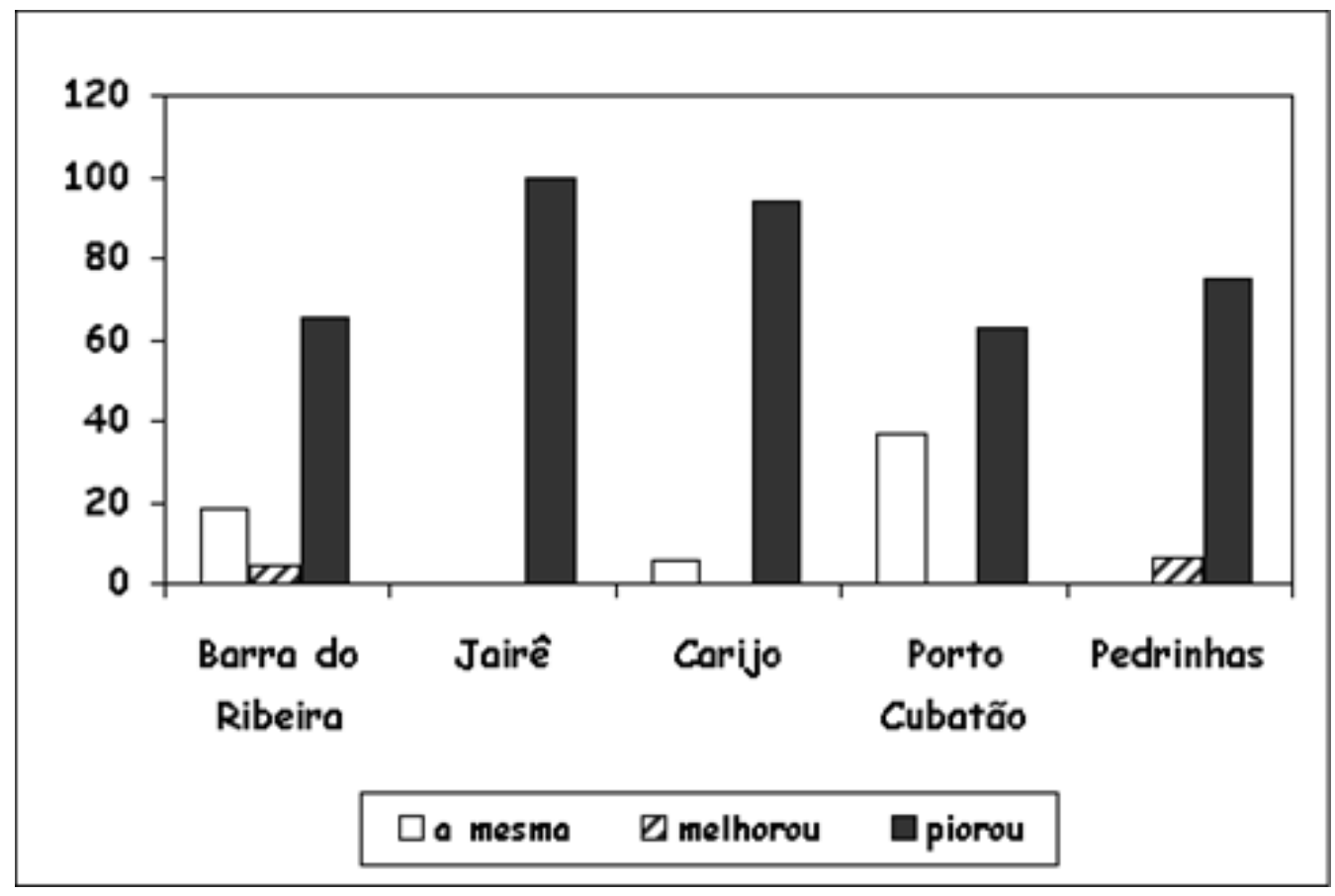

Figura 6 - Opinião dos pescadores artesanais sobre a qualidade dos pesqueiros em relação aos anos anteriores (\% de citação nas entrevistas)

Em outros pontos do litoral brasileiro também se constatou avaliação semelhante por parte dos pescadores, com relação às condições atuais da atividade pesqueira. Em Ubatuba, Clauzet (2000) mostra a opinião dos pescadores, sobre a diminuição na quantidade de peixes na Enseada do Mar Virado nas últimas décadas. Eles atribuem o fato às causas como: grandes barcos de indústrias pesqueiras, a quantidade de lixo no mar, o aumento do movimento de turistas com embarcações e o aumento da pesca esportiva na região. Em Praia Grande (SP), a diminuição do esforço de pesca artesanal é conseqüência direta de problemas econômicos como aumento do preço da gasolina, combustível utilizado por motores de popa, e a competição de preço do pescado, entre o capturado por pescadores locais e o capturado pela pesca industrial (Bertozzi, 2002). 
Lopes (2004), comparou diferentes períodos da atividade pesqueira de uma comunidade caiçara de Ubatuba (SP) e verificou que atualmente vem ocorrendo uma diminuição na captura anual de pescado, assim como no número de espécies presentes nos desembarques pesqueiros.

Segundo Diegues (1988b), as principais limitações ao desenvolvimento da pesca artesanal são: crescente degradação ambiental, conflitos com a pesca industrial, conflitos de posse de terra/praia, limitações da força de trabalho, falta de organização dos pescadores e comercialização. Além disso, o autor ainda aponta que o modelo de crescimento econômico dos últimos anos, concentrador da renda e voltado para a exportação através de grandes empresas, veio acentuar o abandono pelo qual passa a pequena produção tanto agrícola quanto pesqueira e, em particular, a pesca artesanal.

No entanto, um extenso conhecimento acerca da pesca e dos peixes ainda está fortemente presente no cotidiano das comunidades caiçaras do Vale do Ribeira.

\subsection{Etnoictiologia Caiçara}

Através do conhecimento dos pescadores artesanais entrevistados, foi confeccionada uma listagem com as espécies da ictiofauna da região do Vale do Ribeira. Esta listagem (anexo D) reúne todas as espécies citadas por todos os pescadores entrevistados em todos os municípios abrangidos no Projeto “Os peixes e a Pesca no Sul de São Paulo” (Biota/ Fapesp, processo 99/04529-7), do qual este trabalho fez parte, totalizando 128 etnoespécies. Alguns exemplares foram coletados, fixados e identificados, enquanto que outras espécies foram identificadas ao menos até o gênero através da descrição dos pescadores. As espécies que não puderam ser coletadas e identificadas e tão pouco descritas pelos pescadores foram apenas referidas como etnoespécies.

Com base nas entrevistas preliminares, foram definidas as espécies de peixes que fariam parte do levantamento etnoictiológico (Tabela 6), totalizando 122 entrevistas de etnoictiologia com 54 pescadores. As espécies determinadas correspondem àquelas citadas pelos pescadores como as mais capturadas e mais comercializadas. A escolha 
destas espécies levou em consideração, a importância destas para a atividade pesqueira de cada comunidade e para a região de forma geral.

Tabela 6. Espécies definidas para o levantamento etnoictiológico e seus respectivos números de entrevistas em cada comunidade

\begin{tabular}{lcccccc}
\hline \multicolumn{1}{c}{ Espécie } & $\begin{array}{c}\text { Barra do } \\
\text { Ribeira }\end{array}$ & Jairê & Carijo & $\begin{array}{c}\text { Porto } \\
\text { Cubatão }\end{array}$ & Pedrinhas & total \\
\hline $\begin{array}{l}\text { Robalo } \\
\text { (Centropomus sp.) }\end{array}$ & 3 & - & - & 9 & 7 & $\mathbf{1 9}$ \\
$\begin{array}{l}\text { Manjuba } \\
\text { (Anchioviella lepidentostole) }\end{array}$ & 14 & 9 & - & - & - & $\mathbf{2 3}$ \\
$\begin{array}{l}\text { Tainha } \\
\text { (Mugil sp.) }\end{array}$ & 2 & - & 13 & 10 & 6 & $\mathbf{3 1}$ \\
$\begin{array}{l}\text { Parati } \\
\text { (Mugil sp.) }\end{array}$ & - & - & 12 & 8 & 6 & $\mathbf{2 6}$ \\
$\begin{array}{l}\text { Pescada } \\
\text { Cynoscion sp.) }\end{array}$ & - & - & - & 7 & 5 & $\mathbf{1 2}$ \\
$\begin{array}{l}\text { Sororoca } \\
\text { Scomberomorus brasiliensis) } \\
\text { Total }\end{array}$ & - & - & 11 & - & - & $\mathbf{1 1}$ \\
\hline
\end{tabular}

Além das espécies, também foram definidos os aspectos ecológicos e comportamentais sobre os peixes a serem analisados separadamente: etnoespécies (tipos de peixes conhecidos na região), descrição do peixe (diferenças entre jovens e adultos e diferenças entre machos e fêmeas), hábitat (distribuição vertical e horizontal), alimentação (dieta e predação), técnicas para captura, sazonalidade (época de maior captura), reprodução.

\section{As Etnoespécies}

Segundo os pescadores, cada peixe pode ter mais de uma variedade, ou seja, no grupo do robalo, por exemplo, podem existir vários tipos de robalo, como o robalo peva, o robalo flecha, entre outros. Neste trabalho estas variedades foram consideradas como etnoespécies. Dessa forma, foram citadas diversas etnoespécies para cada um dos peixes mencionados nas entrevistas (Tabela 7). 
Tabela 7. Etnoespécies citadas pelos pescadores artesanais

\begin{tabular}{|c|c|c|c|c|c|}
\hline Robalo & Manjuba & Tainha & Parati & Pescada & Sororoca \\
\hline Robalo & Manjuba & Tainha & Parati & Pescada & Sororoca \\
\hline Robalão & Manjubão & Tainha tara & Parati guaçú & Pescadinha & Cavala \\
\hline Robalo chato & Manjuba prego & Tainha grande & Parati pema & Pescada amarela & \\
\hline Robalo flecha & Preguinho & Virote & Parati Poá & Pescada branca & \\
\hline Robalo peva & & Virotão & Parati chorão & Pescada jaguara & \\
\hline Robalo cambuiapeva & & Tainhota & Parati flecha & Pescada olhuda & \\
\hline Robalo galhudo & & Virotinho & Parati do rio & Pescada cambucu & \\
\hline Robalo peba guaçu & & & Parati sabão & Pescada sacu & \\
\hline Robalo tirrinha & & & Parati barbado & Pescada banana & \\
\hline Robalo água branca & & & & Pescada fogueta & \\
\hline
\end{tabular}

Costa-Neto \& Marques (2000c), num estudo realizado em Siribinha (BA), verificaram que a taxonomia etnoictiológica dos pescadores consiste numa classificação hierárquica, incluindo etnoespécies dentro de etnofamílias e estas na categoria popular dos “peixes”.

Os pescadores entrevistados apenas diferenciaram as etnoespécies pertencentes aos grupos dos peixes definidos para este estudo. Portanto, uma análise mais detalhada desta relação de parentesco entre os peixes (etnofamílias) não pôde ser realizada. Porém, a identificação de etnofamílias tem sido um importante aspecto abordado pelos estudos de etnoictiologia. Paz \& Begossi (1996), encontraram componentes de etnofamílias importantes não apenas porque são pescados, consumidos e comercializados, mas também porque podem ser perigosos, baseando-se esta distinção em fatores utilitários.

Para os pescadores de Siribinha (BA) estudados por Costa-Neto \& Marques (2000c), as comparações de semelhanças são evidenciadas através de expressões tais como: “é do mesmo jeito”, “é da mesma família”, “é a mesma coisa de”, “tem o mesmo sistema de”.

Num estudo realizado por Souza \& Barrella (2001), os pescadores da Estação Ecológica de Juréia Itatins atribuem uma relação de parentesco entre as espécies de tainha e parati, que segundo eles, são bem parecidos e portanto, são parentes. Segundo os autores, isto está de acordo com a literatura científica, pois através de identificação taxonômica (Menezes \& Figueiredo, 1985), verificaram que, tanto a tainha quanto o parati pertencem à mesma ordem (Perciformes), família (Mugilidae) e gênero (Mugil), 
explicando a semelhança encontrada entre os dois, o que faz com que os pescadores os classifiquem como “parentes”.

Neste trabalho não foram apontadas pelos pescadores relações de parentesco entre as tainhas e os paratis. Embora se saiba que é uma família de importância para as comunidades caiçaras do litoral sul de São Paulo e que os pescadores desta região possuem um conhecimento detalhado sobre estas espécies (Hanazaki, 2001). Os pescadores que participaram deste trabalho se referiram a elas separadamente, citando inclusive as informações questionadas para cada uma delas, mesmo que em alguns momentos estas informações apresentassem semelhanças. Como por exemplo, no caso dos itens alimentares, onde ambos se alimentam de itens como limo, lama, espuma, etc. Tal conhecimento está de acordo com a literatura cientifica (Menezes \& Figueiredo, 1985) que aponta que estas espécies se alimentam de matéria vegetal retirada do lodo ou substrato em que vivem. Os principais predadores (boto, espada, cação, etc.) citados também foram semelhantes para as duas etnoespécies.

A classificação popular dos peixes obedece a certos aspectos, tais como: o hábitat, a morfologia e a etologia (Silva et al., 1990; Costa-Neto \& Marques, 2000c). Quanto ao hábitat, os peixes podem ser: de represa, de lama, de fundo, de toca, de rio, de brejo. Quanto à morfologia, podem ser: pequeno, grande, roliço, fino, grosso, largo, liso, de escama grande (cascuda), de dente, de esporão, entre outros. E quanto à etologia, podem ser classificados como: brabo, manso, desova no mar, desova no rio, desova nas pedras, já põe os filhotinhos, etc. Segundo Mourão \& Nordi (2002a), coloração, forma do corpo ou traços característicos de parte dele, tamanho do organismo ou de parte do corpo, tipos de escamas e nadadeiras, são detalhes morfológicos muito usados.

Costa-Neto \& Marques (2000a) estudaram o conhecimento dos pescadores de Siribinha (BA), sobre aspectos etológicos dos peixes e apontam que a percepção dos pescadores relacionada com a etologia dos peixes implica na ampliação do conjunto de informações disponíveis à captura dos recursos pesqueiros.

Paz \& Begossi (1996) e Mourão (2000) apontam a morfologia como um critério fundamental na classificação popular. A cor, ausência ou presença de escamas, formato do corpo, anatomia externa, fazem parte desses critérios. Begossi \& Figueiredo (1995), 
ainda apontam para o fato de que as espécies com nomes binomiais, normalmente levam em seu segundo nome também características morfológicas bem visíveis. Em um estudo realizado por Begossi \& Garavello (1990), em comunidades ribeirinhas do Rio Tocantins, também foram observados critérios morfológicos e ecológicos usados pelos pescadores para a classificação das espécies de peixe. As formas da cabeça e da boca são importantes, além dos tipos de escamas (fina ou grossa) e da pigmentação. Alguns exemplos citados por esses autores são a "lampréia-bico-fino" (Ramphychthys marmoratus), o "piau-cabeça-gorda” (Leporinus friderici) e o “cará-oião" (Chaetobranchus flavescens). Aspectos ecológicos usados na classificação popular relacionam características do hábitat ou substrato aos grupos de peixes, como os "de lago”, “da pedra”, etc.

Marques (2001), faz uma análise sobre as conexões que os seres humanos mantêm com a natureza, e sugere 5 conexões: homem/animal, homem/mineral, homem/vegetal, homem/homem e homem/sobrenatural. Seguindo esta análise, CostaNeto \& Marques (2000a), observaram diferentes etnocategorias tróficas em relação aos peixes, presentes no etnoconhecimento e etnoclassificação dos pescadores de Siribinha (BA). Algumas são relacionadas à conexão homem/vegetal, e dentre elas os pescadores citaram "peixes que comem limo”, como exemplo a tainha e a carapeva.

\section{Descrição dos Peixes}

Para a maioria (72,95\%) dos pescadores, todos os peixes são diferenciados entre peixes adultos e filhotes pelo seu tamanho, ou seja, peixes adultos são maiores do que os peixes filhotes. Porém para algumas espécies os pescadores atribuem outras diferenças como por exemplo, a tainha que quando ainda é filhote é chamada de virote, embora tenha as mesmas características morfológicas dos adultos. Outro exemplo é o caso das pescadas, em que os filhotes são mais “finos” que os adultos.

A diferenciação entre os peixes machos e fêmeas é feita pelos pescadores, através da observação da ova do peixe, pois segundo eles não existe outra maneira de se diferenciar (Figura 7). A literatura cientifica aponta que na maioria dos casos, realmente não existem características morfológicas externas que possam ser observadas para a 
diferenciação de sexo. Segundo Vazzoler (1996), a grande maioria dos peixes não apresenta caracteres sexuais secundários, sendo necessário dissecar os indivíduos para a observação das gônadas e identificação do sexo.

As gônadas são as estruturas reprodutivas dos peixes e são diferenciadas entre masculinas (testículos) e femininas (ovários), sendo que estas se apresentam, de acordo com sua fase de maturação, com diferentes aspectos (Holfing et al., 1995). As gônadas masculinas, por exemplo, na fase imatura (estádio A) são reduzidas e as gônadas femininas em fase de maturação se tornam visíveis a olho nu e com coloração mais forte (Vazzoler, 1996). Tal fato pode explicar uma das respostas mais generalizadas (22,95\%), que é a de que os peixes fêmeas têm ova, enquanto que os machos não têm.

Outra forma de diferenciação empregada foi a observação da cor da ova (Figura 7). Os machos possuem ova branca, enquanto que as fêmeas podem conter ova vermelha (19,67\%), ou ova amarela (13,11\%). De acordo com Vazzoler (1996), as gônadas masculinas apresentam forma alongada e sua coloração é esbranquiçada, enquanto que as gônadas femininas apresentam forma alongada-tubular, nas fases iniciais de desenvolvimento são translúcidas e nas fases seguintes, sua coloração varia bastante, em geral, entre amarelo, amarelo-rosado e avermelhado.

Como exposto anteriormente, os caracteres sexuais primários, relativos ao processo reprodutivo propriamente dito, são os órgãos reprodutores, as gônadas, que requerem dissecação para o reconhecimento. No entanto, além destes, que estão presentes em todas as espécies, podem existir outros caracteres secundários de presença restrita a algumas espécies. Os exemplos de caracteres secundários são a forma do corpo (algumas fêmeas podem apresentar o ventre mais desenvolvido), o tamanho (fêmeas de espécies que não cuidam da prole, podem ser maiores do que os machos) e o formato das nadadeiras (em algumas espécies, os machos podem apresentar os raios da peitoral mais longos) (Vazzoler, 1996). Este fato também foi identificado com as respostas dos pescadores, onde segundo eles, em relação ao formato do corpo, os machos podem ser mais compridos e as fêmeas mais curtas $(3,28 \%)$ ou os machos são mais finos e as fêmeas mais grossas $(4,10 \%)$. 


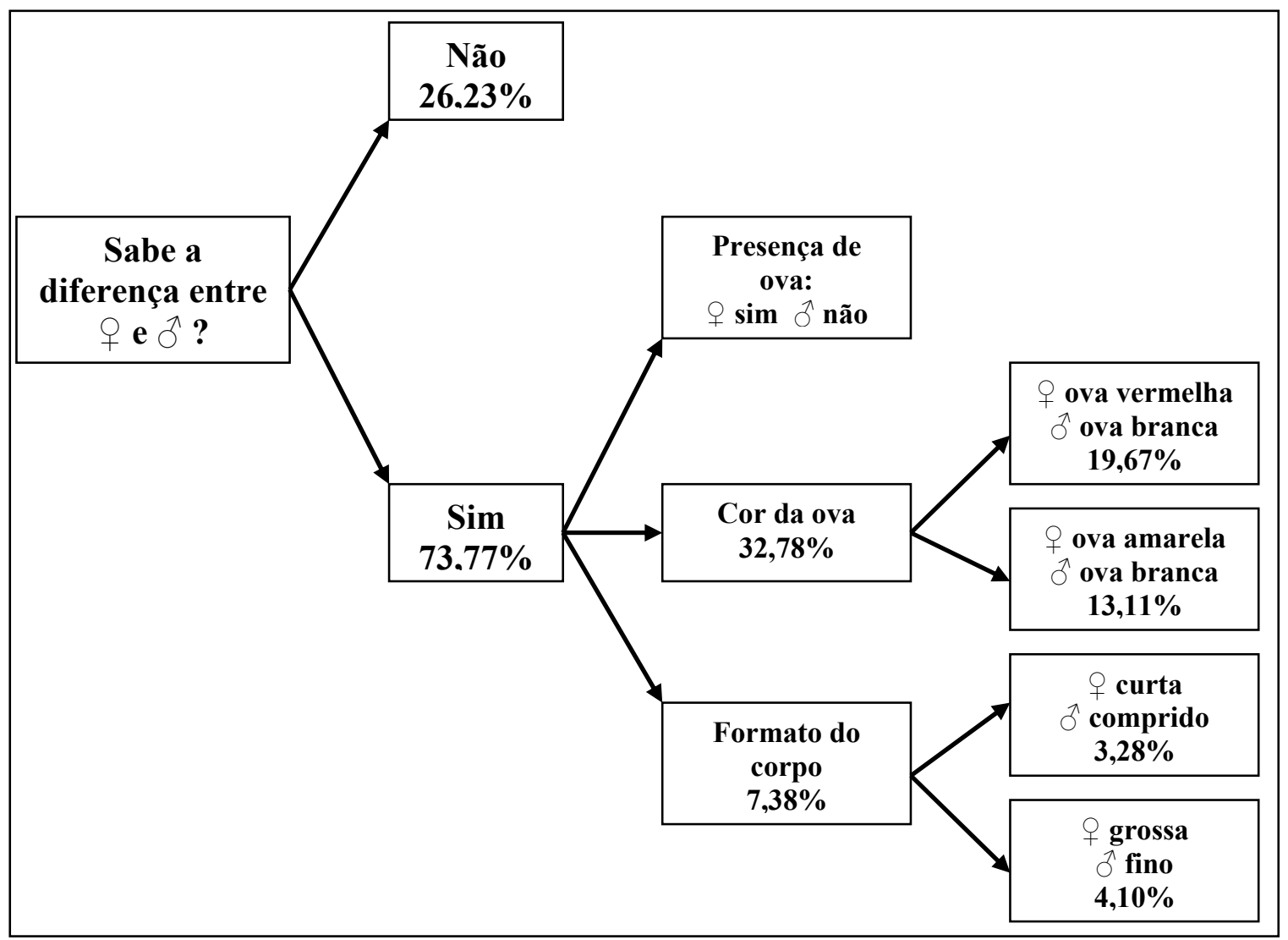

Figura 7 - Conhecimento dos pescadores artesanais sobre a diferenciação sexual dos peixes

Alguns pescadores citaram algumas particularidades sobre algumas espécies, como por exemplo, no caso da manjuba, em que todas são hermafroditas (segundo 7,14\% dos pescadores da Barra do Ribeira), ou seja, todas têm ova e desovam. Em 26,23\% das entrevistas, os pescadores não sabiam a diferença entre machos e fêmea.

Souza \& Barrella (2001), num estudo etnoictiológico realizado em uma comunidade de pescadores da Estação Ecológica de Juréia Itatins, também verificaram o conhecimento dos pescadores sobre a diferenciação entre machos e fêmeas. Segundo esses autores, os pescadores entrevistados mostraram-se muito observadores, pois $92 \%$ deles afirmaram que é possível distinguir machos de fêmeas. E essa diferenciação leva em conta a cor da ova do peixe (se a ova for branca, o peixe é macho, e se for vermelha, o peixe é fêmea). Costa-Neto \& Marques (2000c), verificaram em Siribinha (BA) que características morfológicas são usadas pelos pescadores quando realizam a distinção 
entre os sexos. Como exemplos, os autores citam as falas dos pescadores: “... o aniquim macho (Thalassophryne nattereri) é seco, todo fininho e a fêmea tem barriga grande...”, “... a carapeba fêmea (Diapterus rhombeus) é mais longa que o macho; ele é maior, cresce mais...”.

\section{Habitat}

Em relação ao habitat dos peixes, pode-se verificar que os pescadores diferenciam os ambientes de acordo com as regiões onde estes são capturados e também de acordo com a posição em que estes são capturados na coluna d’água. Dessa forma, notam-se dois tipos de distribuições: horizontal e vertical. Na distribuição horizontal feita pelos pescadores foram diferenciados os ambientes de mar, estuário (barra do rio) e canal (Tabela 8).

Todas as espécies de peixes foram distribuídas pelos pescadores nos ambientes já citados, entretanto, as porcentagens de citação foram diferentes para cada comunidade. No caso do robalo, por exemplo, para 100\% dos pescadores da Barra do Ribeira este vive no mar; enquanto que em Porto Cubatão e Pedrinhas, este pode ser capturado também na barra do rio e no canal.

Mesmo com as opiniões diferindo de comunidade para comunidade em relação às porcentagens de citação, o conhecimento dos pescadores mostra-se semelhante à literatura científica. Autores como Figueiredo \& Menezes (1978; 1980; 2000) e Menezes \& Figueiredo, (1980; 1985) utilizam denominações como “águas costeiras”, “águas estuarinas”, “estuários”, “águas doces” e “águas de baixa salinidade”, o que corresponde ao que os pescadores chamam de: “mar”, "barra do rio” e “canal”.

No Jairê 88,88\% dos pescadores entrevistados apontaram que a manjuba vive a maior parte de sua vida nas regiões próximas às barras dos rios, o que está de acordo com a literatura cientifica (Figueiredo \& Menezes, 1978) que afirma que esta espécie tem hábitos costeiros e algumas penetram nos rios, enquanto outras vivem permanentemente em água doce. A comunidade do Jairê localiza-se mais ao interior do município de Iguape e pratica a pesca da manjuba na extensão do Rio Ribeira e na barra do mesmo rio. 
Tabela 8. Comparação entre o conhecimento dos pescadores sobre a distribuição horizontal dos peixes e a literatura científica (\% de citação nas entrevistas)

\begin{tabular}{|c|c|c|c|c|c|c|c|}
\hline \multirow{2}{*}{\multicolumn{2}{|c|}{ Espécies }} & \multicolumn{5}{|c|}{ Distribuição Horizontal segundo os pescadores } & \multirow{3}{*}{$\begin{array}{c}\text { Distribuição } \\
\text { horizontal segundo a } \\
\text { literatura }^{*}\end{array}$} \\
\hline & & $\begin{array}{c}\begin{array}{c}\text { Barra } \\
\text { do } \\
\text { Ribeira } \\
(\mathbf{n}=\mathbf{1 9})\end{array} \\
100\end{array}$ & $\begin{array}{c}\text { Jairê } \\
(n=9)\end{array}$ & $\begin{array}{c}\begin{array}{c}\text { Carijo } \\
(n=36)\end{array} \\
-\end{array}$ & $\begin{array}{c}\begin{array}{c}\text { Porto } \\
\text { Cubatão } \\
(\mathbf{n}=\mathbf{3 4})\end{array} \\
55,55\end{array}$ & $\begin{array}{c}\begin{array}{c}\text { Pedrinhas } \\
(\mathbf{n}=24)\end{array} \\
5714\end{array}$ & \\
\hline Robalo & $\begin{array}{l}\text { Mar } \\
\text { Rio } \\
\text { Canal } \\
\text { Totais (n) }\end{array}$ & $\begin{array}{c}100 \\
0 \\
0 \\
\mathbf{3}\end{array}$ & $\begin{array}{l}- \\
- \\
- \\
-\end{array}$ & $\begin{array}{l}- \\
- \\
- \\
-\end{array}$ & $\begin{array}{c}55,55 \\
33,33 \\
66,66 \\
\mathbf{9}\end{array}$ & $\begin{array}{c}57,14 \\
14,28 \\
100 \\
7\end{array}$ & \\
\hline Manjuba & $\begin{array}{l}\text { Barra do rio } \\
\text { Mar }\end{array}$ & $\begin{array}{c}7,14 \\
78,57\end{array}$ & $\begin{array}{c}88,88 \\
0\end{array}$ & $\begin{array}{l}- \\
- \\
-\end{array}$ & $\begin{array}{l}- \\
- \\
-\end{array}$ & $\begin{array}{l}- \\
- \\
-\end{array}$ & $\begin{array}{l}\text { Hábitos costeiros. } \\
\text { Águas de baixa } \\
\text { salinidade. Algumas } \\
\text { penetram nos rios, } \\
\text { outras vivem } \\
\text { permanentemente em } \\
\text { água doce. }\end{array}$ \\
\hline Tainha & $\begin{array}{l}\text { Mar } \\
\text { Canal } \\
\text { Rio } \\
\text { Totais (n) }\end{array}$ & $\begin{array}{c}100 \\
0 \\
0 \\
2\end{array}$ & $\begin{array}{l}- \\
- \\
- \\
-\end{array}$ & $\begin{array}{c}84,61 \\
15,38 \\
15,38 \\
\mathbf{1 3}\end{array}$ & $\begin{array}{l}50 \\
90 \\
10 \\
\mathbf{1 0}\end{array}$ & $\begin{array}{c}33,33 \\
83.33 \\
0 \\
6\end{array}$ & $\begin{array}{l}\text { Estuários e zonas } \\
\text { costeiras. }\end{array}$ \\
\hline Parati & $\begin{array}{l}\text { Mar } \\
\text { Canal } \\
\text { Rio } \\
\text { Totais (n) }\end{array}$ & $\begin{array}{l}- \\
- \\
- \\
-\end{array}$ & $\begin{array}{l}- \\
- \\
- \\
-\end{array}$ & $\begin{array}{c}25 \\
41,66 \\
50 \\
\mathbf{1 2}\end{array}$ & $\begin{array}{c}12,5 \\
87,5 \\
0 \\
\mathbf{8}\end{array}$ & $\begin{array}{c}16,66 \\
100 \\
0 \\
\mathbf{6}\end{array}$ & $\begin{array}{l}\text { Estuários e zonas } \\
\text { costeiras. }\end{array}$ \\
\hline Pescada & $\begin{array}{l}\text { Mar } \\
\text { Canal } \\
\text { Rio } \\
\text { Barra do rio } \\
\text { Totais (n) }\end{array}$ & $\begin{array}{l}- \\
- \\
- \\
- \\
-\end{array}$ & $\begin{array}{l}- \\
- \\
- \\
- \\
-\end{array}$ & $\begin{array}{l}- \\
- \\
- \\
- \\
-\end{array}$ & $\begin{array}{c}42,86 \\
100 \\
14,28 \\
0 \\
7\end{array}$ & $\begin{array}{c}40 \\
100 \\
0 \\
20 \\
5\end{array}$ & $\begin{array}{l}\text { Águas costeiras e } \\
\text { zonas estuárinas. }\end{array}$ \\
\hline Sororoca & $\begin{array}{l}\text { Mar } \\
\text { Canal } \\
\text { Totais (n) }\end{array}$ & $\begin{array}{l}- \\
- \\
-\end{array}$ & $\begin{array}{l}- \\
- \\
-\end{array}$ & $\begin{array}{c}100 \\
9,09 \\
11\end{array}$ & $\begin{array}{l}- \\
- \\
-\end{array}$ & $\begin{array}{l}- \\
- \\
-\end{array}$ & $\begin{array}{l}\text { Águas costeiras, de } \\
\text { superfície, } \\
\text { relativamente comum } \\
\text { na costa brasileira. }\end{array}$ \\
\hline
\end{tabular}

De acordo com Menezes \& Figueiredo (1985), as espécies pertencentes ao gênero Mugil são distribuídas horizontalmente nos estuários e zonas costeiras correspondendo mais uma vez com a maioria das citações dos pescadores (Tabela 8), com exceção de 15,38\% dos pescadores do Carijo e 10\% dos pescadores de Porto Cubatão que afirmaram que a tainha vive nos rios. Outra exceção foi a respeito do parati que para $50 \%$ dos pescadores do Carijo, também vive nos rios. Tais respostas podem 
estar associadas ao fato de que algumas espécies deste grupo (Mugilidae) são esporadicamente capturadas nos rios, o que também pôde ser verificado pela literatura (Menezes \& Figueiredo,1985) que indica a existência de apenas algumas referências sobre desova destas espécies em lagoas estuarinas ou mesmo em água doce, além de subirem os rios por distâncias consideráveis.

Quanto à pescada, todas as citações corresponderam com as informações gerais da literatura (Menezes \& Figueiredo, 1980) sobre a distribuição horizontal do grupo, com exceção de 14,28\% dos pescadores de Porto Cubatão que mencionaram que as pescadas vivem nos rios. No entanto, segundo a mesma literatura algumas poucas espécies de pescada, de menor abundância e importância econômica vivem em água doce e nas desembocaduras dos rios.

Outros estudos também mostram a correspondência entre o conhecimento dos pescadores e a literatura científica sobre habitats dos peixes. Costa-Neto \& Marques (2000b), estudaram o conhecimento dos pescadores de Conde (BA) com respeito a distribuição temporal e espacial dos recursos pesqueiros e observaram que os pescadores baianos categorizam as diferentes distribuições espaciais como: "peixes do mar", "peixes do rio", "peixes do brejo", "peixes de água doce”, "peixes de lagoa” e "peixes de mar e rio”. Os pescadores da Barra do Una (Peruíbe/SP) estudados por Souza \& Barrella (2001), também diferenciaram os grupos de peixes de acordo com o habitat em que vivem. Segundo eles, existem peixes que vivem apenas nos rios, "os peixes de água doce”, e os "peixes marinhos", que vivem no mar e em águas salobras dos estuários e das desembocaduras dos rios.

Para os pescadores de Siribinha (Costa-Neto \& Marques, 2000b), com relação à dimensão espacial, existe um total de 22 unidades espaciais percebidas, nomeadas e utilizadas. Estas se referem tanto a espaços naturais quanto a espaços artificiais. As unidades espaciais percebidas, divididas em categorias e subcategorias, são empregadas no sistema classificatório dos recursos faunísticos. Este sistema, baseado no habitat, é feito de acordo com: a) percepção das grandes divisões hidrográficas; b) segregação vertical; c) manchas de fundo e d) microhabitats. 
Neste trabalho pode-se verificar que em relação à distribuição vertical, os pescadores separaram os peixes em: peixes de fundo, peixes de meia água e peixes de superfície, acordo com os locais onde estes são capturados e de acordo com os métodos utilizados para captura que expressam a posição que os peixes ocupam na coluna d'água (Tabela 9). Esta posição pode variar, segundo eles, em determinadas épocas e (ou) situações e de acordo com cada espécie. Para alimentação, por exemplo, os peixes podem estar na superfície ou em meia água. Para reprodução, podem estar temporariamente no fundo para desovar.

Tabela 9. Conhecimento dos pescadores sobre a distribuição vertical dos peixes (\% de citação nas entrevistas)

\begin{tabular}{|c|c|c|c|c|c|c|}
\hline \multicolumn{2}{|c|}{$\begin{array}{c}\text { Espécies/distribuição } \\
\text { vertical }\end{array}$} & $\begin{array}{c}\text { Barra do } \\
\text { Ribeira } \\
(n=19)\end{array}$ & $\begin{array}{l}\text { Jairê } \\
(n=9)\end{array}$ & $\begin{array}{l}\text { Carijo } \\
(n=36)\end{array}$ & $\begin{array}{c}\text { Porto } \\
\text { Cubatão } \\
(\mathrm{n}=34)\end{array}$ & $\begin{array}{c}\text { Pedrinhas } \\
(n=24)\end{array}$ \\
\hline Robalo & $\begin{array}{l}\text { Fundo } \\
\text { Meia água } \\
\text { Superfície } \\
\text { Totais (n) }\end{array}$ & $\begin{array}{l}0 \\
0 \\
0 \\
3\end{array}$ & $\begin{array}{l}- \\
- \\
- \\
-\end{array}$ & $\begin{array}{l}- \\
- \\
- \\
-\end{array}$ & $\begin{array}{c}88,88 \\
33,33 \\
44,44 \\
9\end{array}$ & $\begin{array}{c}57,14 \\
28,57 \\
28,57 \\
7\end{array}$ \\
\hline Manjuba & $\begin{array}{l}\text { Fundo } \\
\text { Meia água } \\
\text { Superfície } \\
\text { Totais (n) }\end{array}$ & $\begin{array}{c}42,86 \\
0 \\
35,71 \\
\mathbf{1 4}\end{array}$ & $\begin{array}{c}66,66 \\
22,22 \\
66,66 \\
\mathbf{9}\end{array}$ & $\begin{array}{l}- \\
- \\
- \\
-\end{array}$ & $\begin{array}{l}- \\
- \\
- \\
-\end{array}$ & $\begin{array}{l}- \\
- \\
- \\
-\end{array}$ \\
\hline Tainha & $\begin{array}{l}\text { Fundo } \\
\text { Meia água } \\
\text { Superfície } \\
\text { Totais (n) }\end{array}$ & $\begin{array}{c}50 \\
0 \\
50 \\
2\end{array}$ & $\begin{array}{l}- \\
- \\
- \\
-\end{array}$ & $\begin{array}{c}53,85 \\
0 \\
92,31 \\
\mathbf{1 3}\end{array}$ & $\begin{array}{l}60 \\
- \\
60 \\
10\end{array}$ & $\begin{array}{c}66,66 \\
33,33 \\
50 \\
6\end{array}$ \\
\hline Parati & $\begin{array}{l}\text { Fundo } \\
\text { Meia água } \\
\text { Superfície } \\
\text { Totais (n) }\end{array}$ & $\begin{array}{l}- \\
- \\
- \\
-\end{array}$ & $\begin{array}{l}- \\
- \\
- \\
-\end{array}$ & $\begin{array}{c}75 \\
0 \\
0 \\
\mathbf{1 2}\end{array}$ & $\begin{array}{c}50 \\
0 \\
62,5 \\
\mathbf{8}\end{array}$ & $\begin{array}{c}50 \\
0 \\
66,66 \\
\mathbf{6}\end{array}$ \\
\hline Pescada & $\begin{array}{l}\text { Fundo } \\
\text { Meia água } \\
\text { Superfície } \\
\text { Totais (n) }\end{array}$ & $\begin{array}{l}- \\
- \\
- \\
-\end{array}$ & $\begin{array}{l}- \\
- \\
- \\
-\end{array}$ & $\begin{array}{l}- \\
- \\
- \\
-\end{array}$ & $\begin{array}{c}100 \\
0 \\
0 \\
7\end{array}$ & $\begin{array}{c}80 \\
0 \\
20 \\
5\end{array}$ \\
\hline Sororoca & $\begin{array}{l}\text { Fundo } \\
\text { Meia água } \\
\text { Superfície } \\
\text { Totais (n) }\end{array}$ & $\begin{array}{l}- \\
- \\
- \\
-\end{array}$ & $\begin{array}{l}- \\
- \\
- \\
-\end{array}$ & $\begin{array}{c}36,36 \\
0 \\
100 \\
\mathbf{1 1}\end{array}$ & $\begin{array}{l}- \\
- \\
- \\
-\end{array}$ & $\begin{array}{l}- \\
- \\
- \\
-\end{array}$ \\
\hline
\end{tabular}

A distribuição vertical dos peixes é um aspecto que também foi observado por pescadores de outras comunidades, como a de Conde (BA), estudada por Costa-Neto \& 
Marques (2000b). Neste estudo os autores observaram que quanto à segregação vertical, os pescadores explicitamente reconhecem que as etnoespécies habitam o “rio/estuário”, posicionam-se em três níveis na coluna d’água, distinguindo-as como "peixes de veia d’água”, “peixes de mei água” e “peixes de fundo”. O que se mostra bem semelhante ao conhecimento dos pescadores estudados no presente trabalho.

Além disso, os mesmos autores ainda identificaram uma diferenciação feita pelos pescadores de Conde (BA), em relação aos peixes marinhos, que também foram distribuídos em três níveis em razão da profundidade na qual são coletados: “peixes de fundo”, representados por peixes pescados em profundidades que variam de 35 a 200 metros, "peixes de seco", pescados próximos à costa e "peixes de fundo e seco", representados por indivíduos que habitam diferentes profundidades.

A literatura utilizada para a comparação, neste caso, foi a mesma utilizada para comparar o conhecimento dos pescadores sobre a distribuição horizontal. Entretanto, esta não apresentou informações detalhadas para todas as espécies questionadas.

O que se verificou de concordância foi em relação à pescada, que segundo $100 \%$ dos pescadores de Porto Cubatão e 80\% de Pedrinhas vive no fundo, semelhante a literatura segundo o qual as espécies deste grupo vivem em fundos de lama e areia. Porém, 20\% dos pescadores de Pedrinhas apontaram que as pescadas são peixes de superfície, o que pode ser um evento esporádico, ou seja, segundo eles, em determinadas épocas ou sob determinadas situações estas estão na superfície e não constantemente. Já em relação à sororoca, segundo 100\% dos pescadores entrevistados afirmaram que esta vive na superfície mostrando concordância com Figueiredo \& Menezes (2000). Porém dentre eles, 36,36\% também responderam que as sororocas também podem ser capturadas em determinadas épocas do ano no fundo.

\section{Presas e Predadores}

O conhecimento sobre a alimentação dos peixes é muito diversificado, ou seja, foram citados diversos itens alimentares. A Tabela compara o conhecimento dos pescadores (todos os itens alimentares citados) e a literatura científica (Figueiredo \& Menezes, 1978; 1980; 2000; Menezes \& Figueiredo, 1980; 1985). 
Tabela 10. Cognição comparada sobre as presas dos peixes. Os valores correspondem a \% de citação nas entrevistas

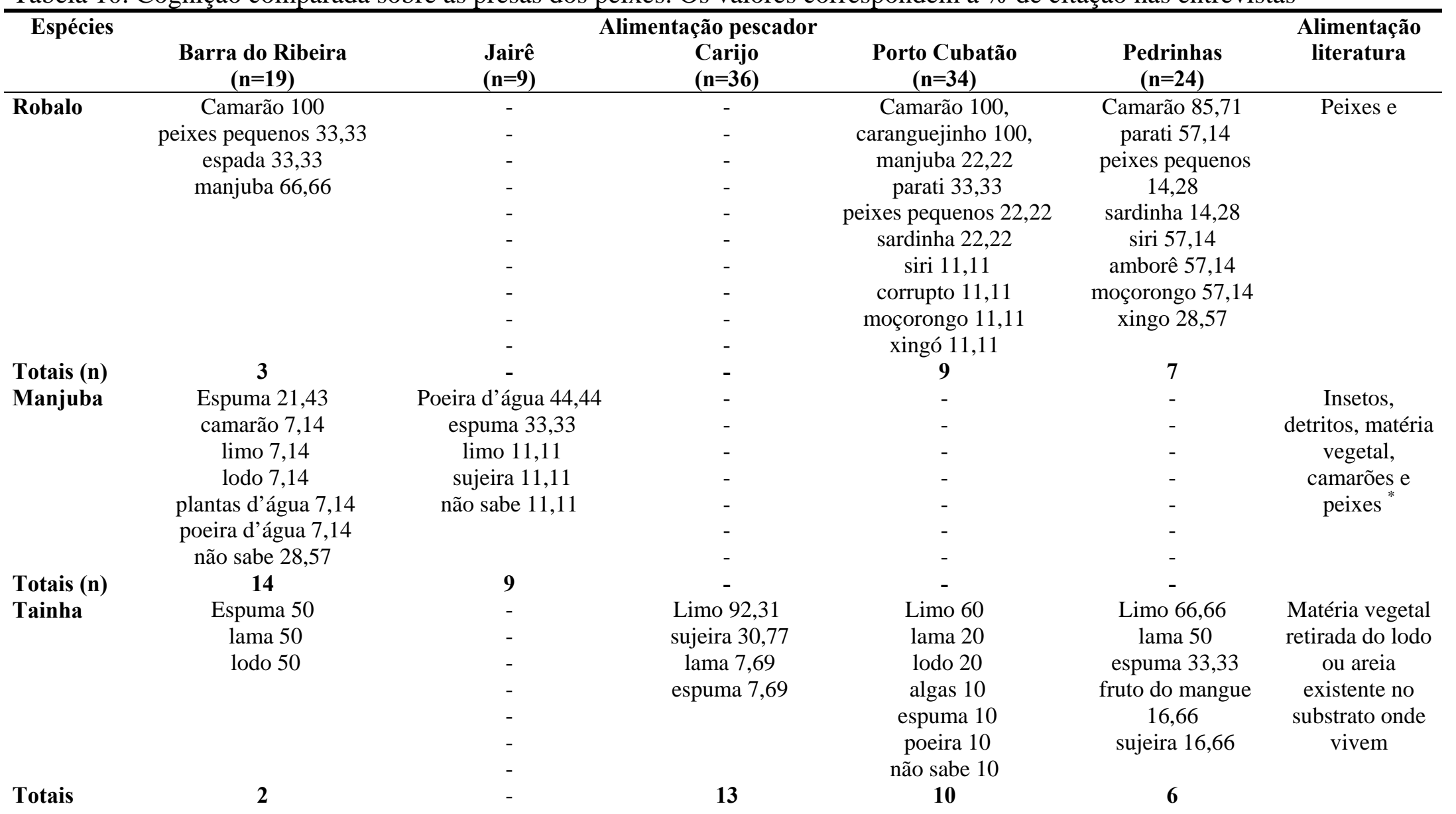


Tabela 10. Cognição comparada sobre as presas dos peixes. Os valores correspondem a \% de citação nas entrevistas

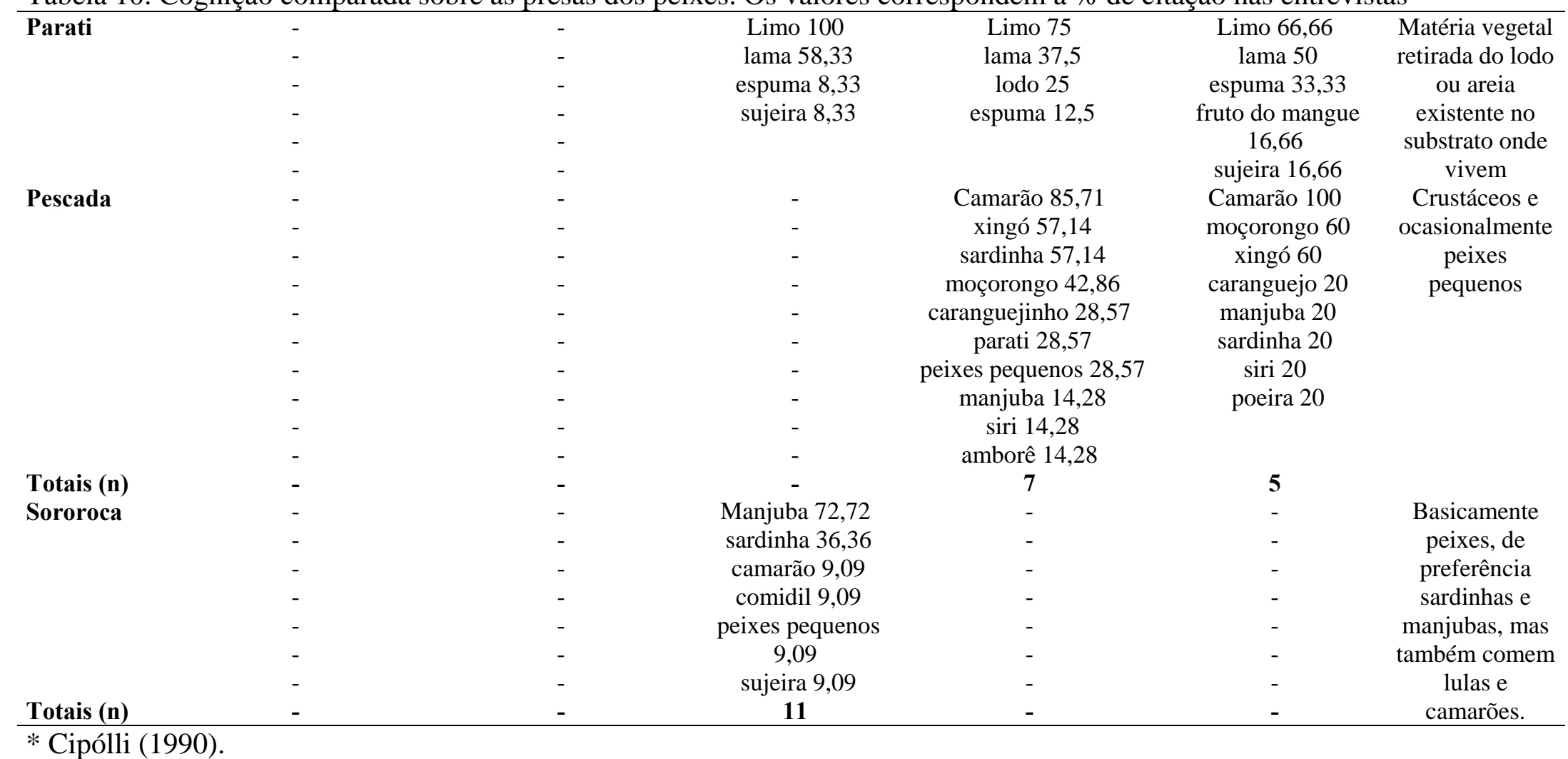


A literatura utilizada para a comparação (Figueiredo \& Menezes, 1978; 1980; 2000; Menezes \& Figueiredo, 1980; 1985) cita de forma geral os grupos que compõe a dieta dos peixes como, por exemplo, peixes, crustáceos, insetos, detritos, matéria vegetal, entre outros. Enquanto que os pescadores são mais específicos ao citarem diversos itens alimentares de cada grupo, ou seja, são citados os nomes dos peixes, o tipo de detrito, etc. Dessa forma, não se notou discordância entre o conhecimento dos pescadores e a literatura científica em relação a alimentação dos peixes. Tal fato corrobora a importância de estudos etnoictiológicos, pois dada a especificidade do conhecimento dos pescadores em relação aos itens alimentares, este pode facilitar os passos convencionais da pesquisa ictiológica, em especial a produção de conhecimento cientifico atual sobre a dieta e ecologia de peixes marinhos.

Além da dieta dos peixes, os pescadores também apresentam um grande conhecimento sobre os diversos predadores dos peixes (Tabela 11).

A literatura ictiológica sobre interações tróficas e predação de peixes marinhos é escassa. No entanto, Lowe-McConnell (1999), analisa o papel dos predadores na manutenção da diversidade de peixes. Segundo esta autora, o elevado número de espécies e indivíduos predadores parece constituir uma característica importante das comunidades tropicais, e são certamente encontradas tanto em comunidades de peixes dulcícolas como marinhos. Admitindo-se que as presas são as espécies mais abundantes e que os predadores mudam para outras presas à medida que o número de presas se reduz, os predadores podem ter um importante papel, permitindo a coexistência de espécies de presas e mantendo seus números abaixo do nível do qual elas poderiam competir umas com as outras por alimento ou por espaço. 
Tabela 11. Predadores dos peixes segundo o conhecimento dos pescadores. Os valores correspondem a \% de citação nas entrevistas

\begin{tabular}{|c|c|c|c|c|c|}
\hline \multirow[t]{2}{*}{ Espécies } & \multicolumn{5}{|c|}{ Predadores } \\
\hline & $\begin{array}{c}\text { Barra do } \\
\text { Ribeira } \\
(n=19)\end{array}$ & $\begin{array}{l}\text { Jairê } \\
(\mathbf{n}=9)\end{array}$ & $\begin{array}{l}\text { Carijo } \\
(\mathbf{n}=36)\end{array}$ & $\begin{array}{c}\text { Porto Cubatão } \\
\quad(n=34)\end{array}$ & $\begin{array}{c}\text { Pedrinhas } \\
(n=24)\end{array}$ \\
\hline \multirow{6}{*}{ Robalo } & Boto 33,33 & - & - & Cação 33,33 & Caranha 28,57 \\
\hline & lontra 33,33 & - & - & caranha 33,33 & boto 14,28 \\
\hline & & - & - & espada 33,33 & mero 14,28 \\
\hline & & - & - & não tem & não tem \\
\hline & & - & - & predador 22,22 & predador 28,57 \\
\hline & & - & - & & não sabe 452,86 \\
\hline Totais (n) & 3 & - & - & 9 & 7 \\
\hline \multirow{7}{*}{ Manjuba } & Robalo 42,86 & Bagre 100 & - & - & - \\
\hline & bagre 49.99 & robalo 88,88 & - & - & - \\
\hline & espada 21,43 & traíra 22,22 & - & - & - \\
\hline & pescada 21,43 & & - & - & - \\
\hline & baiacu 7,14 & & - & - & - \\
\hline & cação 7,14 & & - & - & - \\
\hline & sororoca 7,14 & & - & - & - \\
\hline Totais (n) & 14 & 9 & - & - & - \\
\hline \multirow{10}{*}{ Tainha } & 0 & - & Boto 100 & Boto 90 & Boto 83,33 \\
\hline & 0 & - & cação 76,92 & cação 30 & mero 50 \\
\hline & 0 & - & espada 30,77 & caranha 20 & cação 16,66 \\
\hline & 0 & - & caranha 23,08 & espada 20 & caranha 16,66 \\
\hline & 0 & - & mero 7,69 & mero 20 & lontra 16,66 \\
\hline & 0 & - & anchova 7,69 & anchova 10 & \\
\hline & 0 & - & & cherne 10 & \\
\hline & 0 & - & & jacaré 10 & \\
\hline & 0 & - & & sororoca 10 & \\
\hline & 0 & - & & não sabe 10 & \\
\hline Totais (n) & 2 & - & 13 & 10 & 6 \\
\hline \multirow{12}{*}{ Parati } & - & - & Boto 100 & Boto 62,5 & Boto 100 \\
\hline & - & - & cação 58,33 & bagre 37,5 & mero 83,33 \\
\hline & - & - & caranha 41,66 & pescada 37,5 & pescada 33,33 \\
\hline & - & - & espada 41,66 & robalo 37,5 & robalo 33,33 \\
\hline & - & - & mero 25 & cação 25 & bagre 16,66 \\
\hline & - & - & robalo 25 & espada 25 & jacaré 16,66 \\
\hline & - & - & anchova 8,33 & mero 25 & lontra 16,66 \\
\hline & - & - & pescada & anchova 12,5 & \\
\hline & - & - & amarela 8,33 & badejo 12,5 & \\
\hline & - & - & & caranha 12,5 & \\
\hline & - & - & & prejereba 12,5 & \\
\hline & - & - & & não sabe 12,5 & \\
\hline Totais (n) & - & - & 12 & 8 & 6 \\
\hline
\end{tabular}


Tabela 11. Predadores dos peixes segundo o conhecimento dos pescadores. Os valores correspondem a \% de citação nas entrevistas

\begin{tabular}{lccccc}
\hline Pescada & - & - & - & Espada 57,14 & Espada 60 \\
& - & - & - & cação 28,57 & boto 20 \\
& - & - & - & caranha 14,28 & caranha 20 \\
& - & - & - & & mero 20 \\
& - & - & - & & robalo 20 \\
cação 20 \\
Totais (n) & - & - & - & 7 & $\mathbf{5}$ \\
sororoca & - & - & Espada 90,90 & - & - \\
& - & - & cação 81,81 & - & - \\
Totais (n) & - & - & boto 18,18 & - & - \\
\hline
\end{tabular}

Em relação à alimentação e predação, os pescadores observam comportamentos característicos de cada espécie, como por exemplo, em casos em que outros peixes atacam os peixes que estão emalhados nas redes. Eles observam também o tipo de alimentação de acordo com o que encontram nos estômagos das espécies que capturam, além é claro dos conhecimentos herdados por outras gerações. O homem apontado como um dos principais predadores dos peixes em trabalho anterior (Ramires \& Barrella, no prelo) não foi citado neste trabalho. Isto pode ser reflexo da forma como os pescadores foram entrevistados, ou seja, estes foram questionados sobre quais os animais que se alimentam de peixes e assim, o homem não foi tomado como um "animal predador", pelos pescadores entrevistados.

Com as informações sobre presas (Tabela 10) e predadores (Tabela 11) foram compostas cadeias alimentares simplificadas que mostram as relações tróficas dos peixes segundo o conhecimento dos pescadores. 

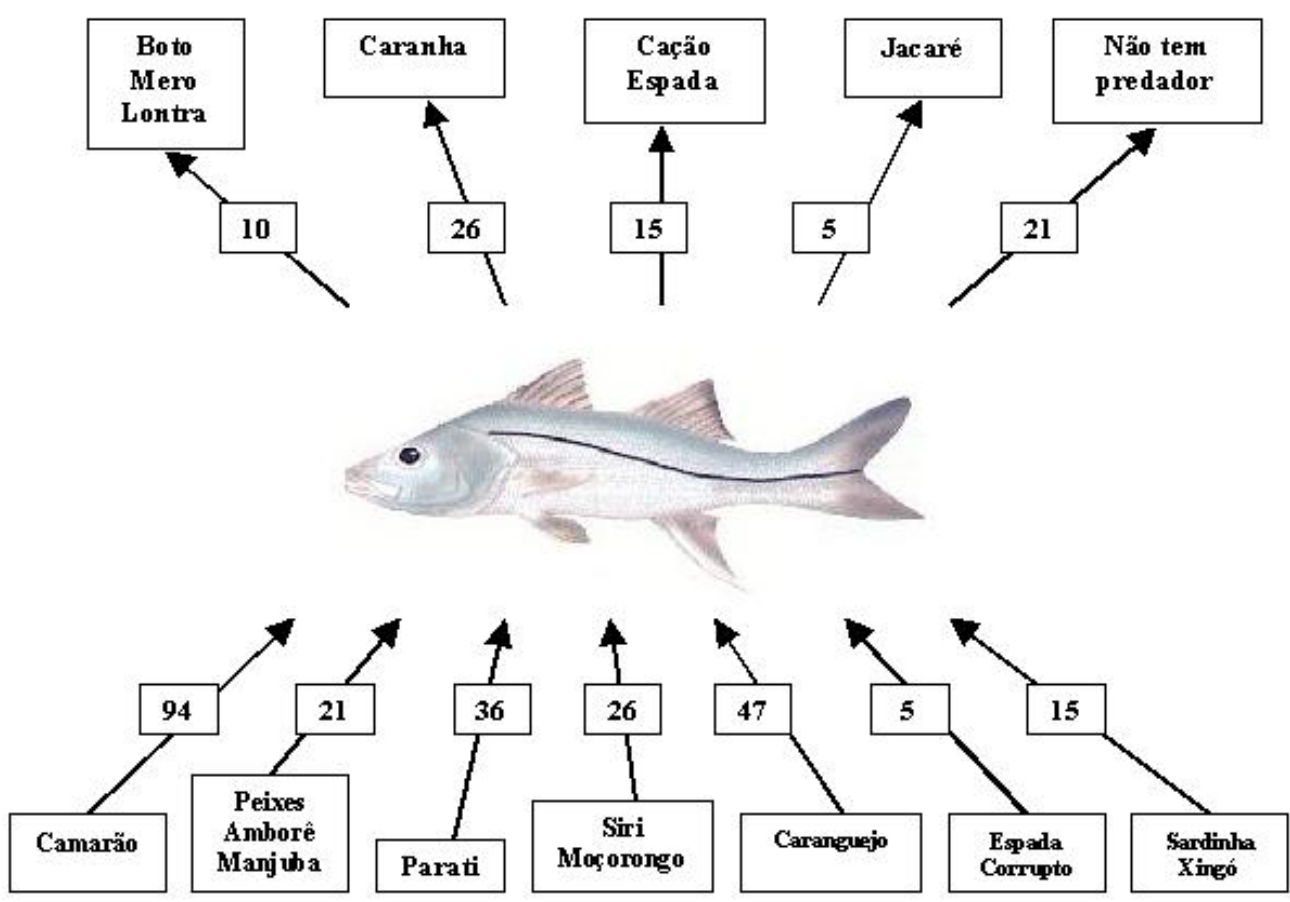

Figura 8 - Relações tróficas do robalo, segundo o conhecimento dos pescadores de Barra do Ribeira, Porto Cubatão e Pedrinhas (os números correspondem às porcentagens de citação nas entrevistas)
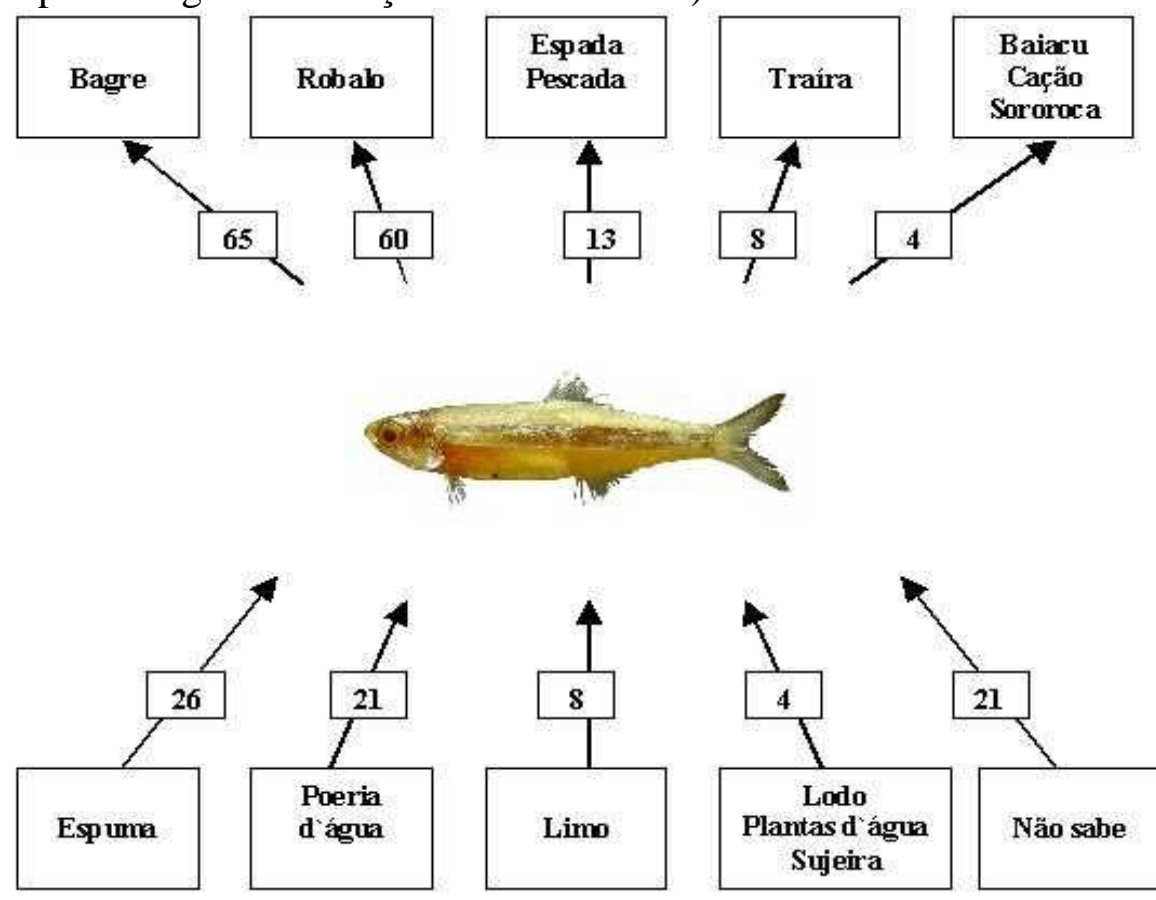

Figura 9 - Relações tróficas da manjuba, segundo o conhecimento dos pescadores da Barra do Ribeira e Jairê (os números correspondem às porcentagens de citação nas entrevistas) 

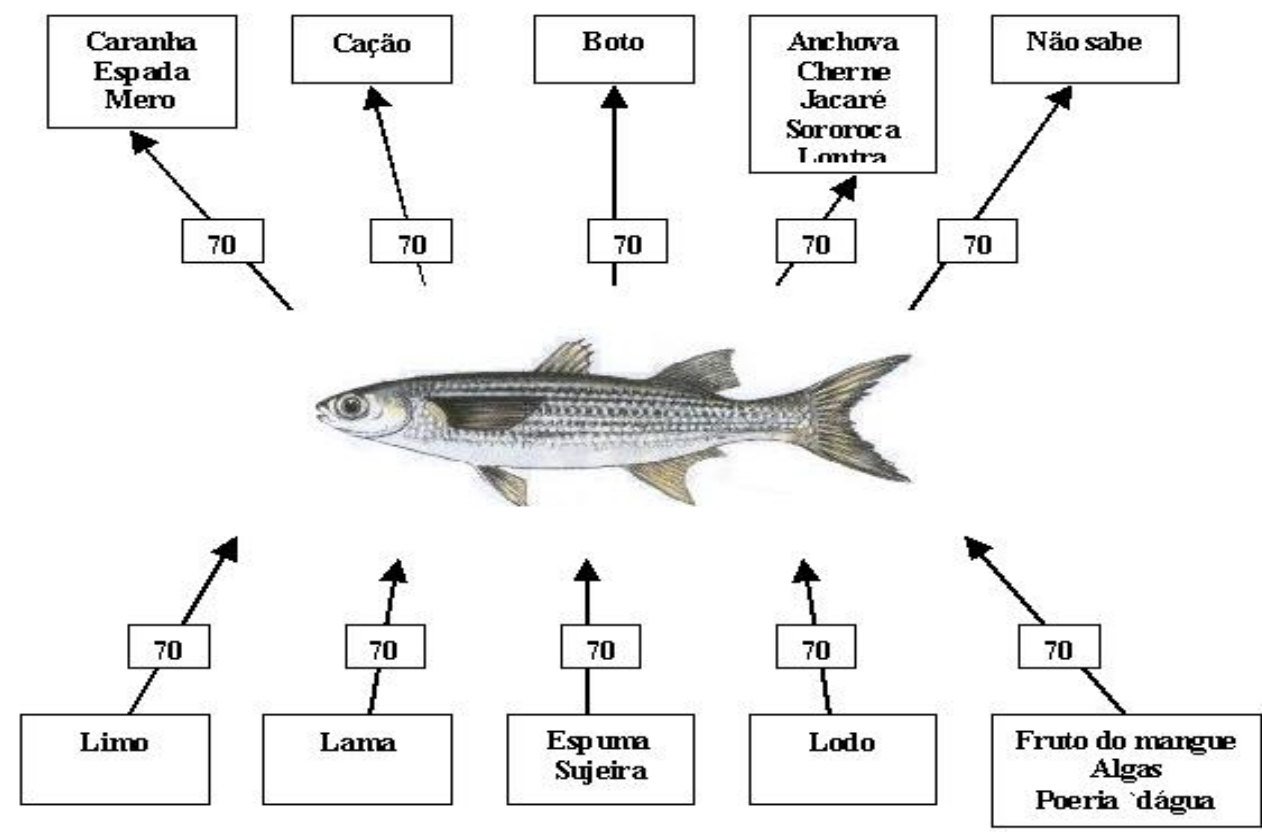

Figura 10 - Relações tróficas da tainha, segundo o conhecimento dos pescadores de Barra do Ribeira, Carijo, Porto Cubatão e Pedrinhas (os números correspondem às porcentagens de citação nas entrevistas)

Segundo os pescadores da Barra do Ribeira, Porto Cubatão e Pedrinhas, o robalo se alimenta de camarão, caranguejo, peixes pequenos, manjuba, parati, sardinha e siri, dentre outros. E serve de alimento para o boto, o cação, a caranha, a espada e o mero (Figura 8).

A manjuba, segundo os pescadores da Barra do Ribeira e do Jairê, se alimenta de espuma presente na superfície, camarão, limo, lodo, poeira d`água, sujeira. Enquanto que seus predadores são: robalo, bagre, espada, pescada (Figura 9).

A tainha é uma das espécies mais importantes na pesca das comunidades da Barra do Ribeira, Carijo, Porto Cubatão e Pedrinhas; e segundo os pescadores destas comunidades, ela se alimenta de itens como: espuma, lama, lodo, limo, sujeira, algas e poeira. Os predadores apontados foram: boto, cação, espada, caranha, mero e lontra (Figura 10).

O item espuma também foi observado em outros estudos realizados sobre o conhecimento dos pescadores. Na comunidade da Barra do Una (Peruíbe/SP), os pescadores chamam esta espuma de "turvança" e a descrevem como uma espuma 
amarelada que flutua sobre a superfície do mar e às vezes dos rios (Souza \& Barrella, 2001). Este fato também foi relatado por Mourão (2000), segundo o qual, os pescadores do estuário do Rio Mamanguape (PB), se referem a essas espécies como peixes que bebem espuma.

O parati é uma espécie freqüentemente relacionada pelos pescadores com a tainha. Segundo a maioria deles, as duas espécies são da mesma família e têm hábitos alimentares e predadores semelhantes. Um exemplo disso pode ser expresso através das citações dos pescadores de Porto Cubatão e Pedrinhas (Figura 11), em que o parati se alimenta, assim como a tainha, de itens como: espuma, limo, lama, sujeira e lodo. Os predadores (também semelhantes aos da tainha) são: boto, cação, caranha, espada, mero, robalo, lontra, dentre outros.

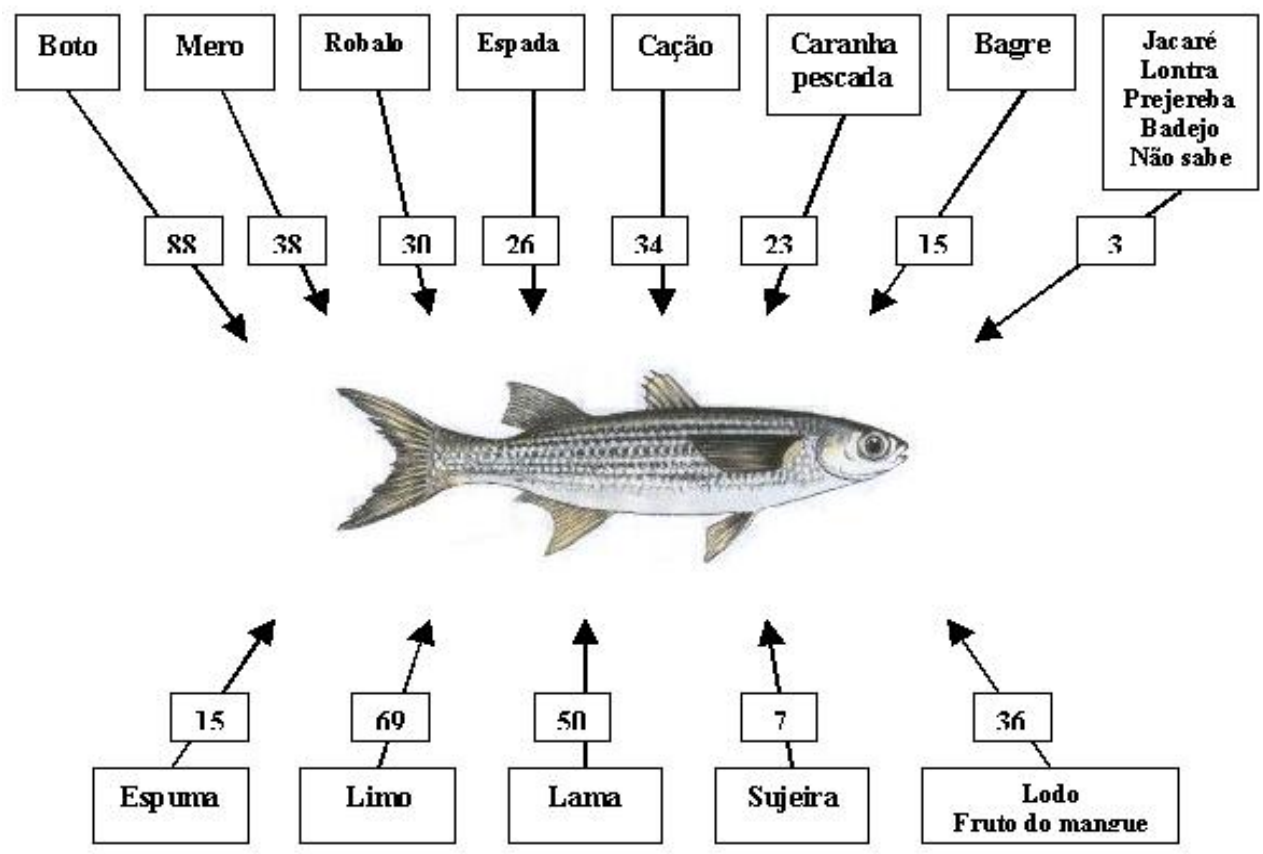

Figura 11 - Relações tróficas do parati, segundo o conhecimento dos pescadores de Porto Cubatão e Pedrinhas (os números correspondem às porcentagens de citação nas entrevistas) 

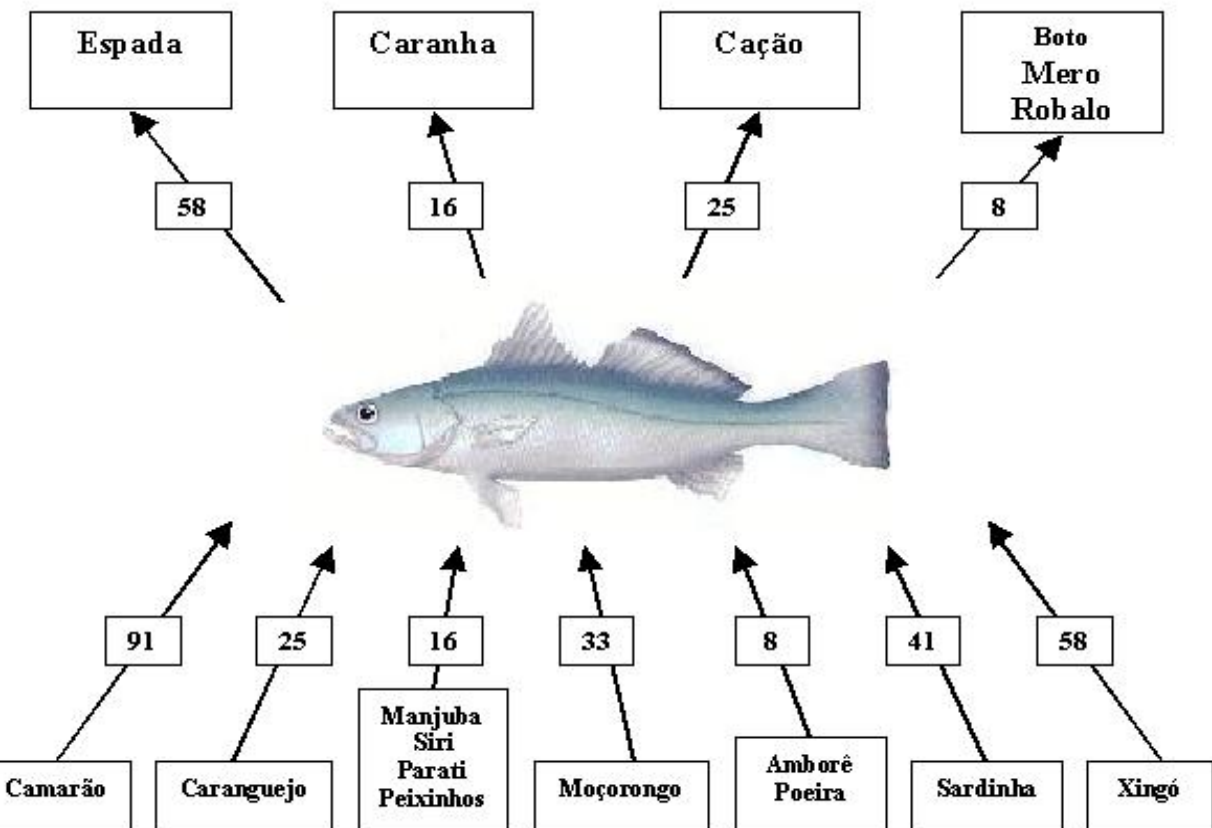

Figura 12 - Relações Tróficas da pescada, segundo o conhecimento dos pescadores de Porto Cubatão e Pedrinhas (os números correspondem às porcentagens de citação nas entrevistas)
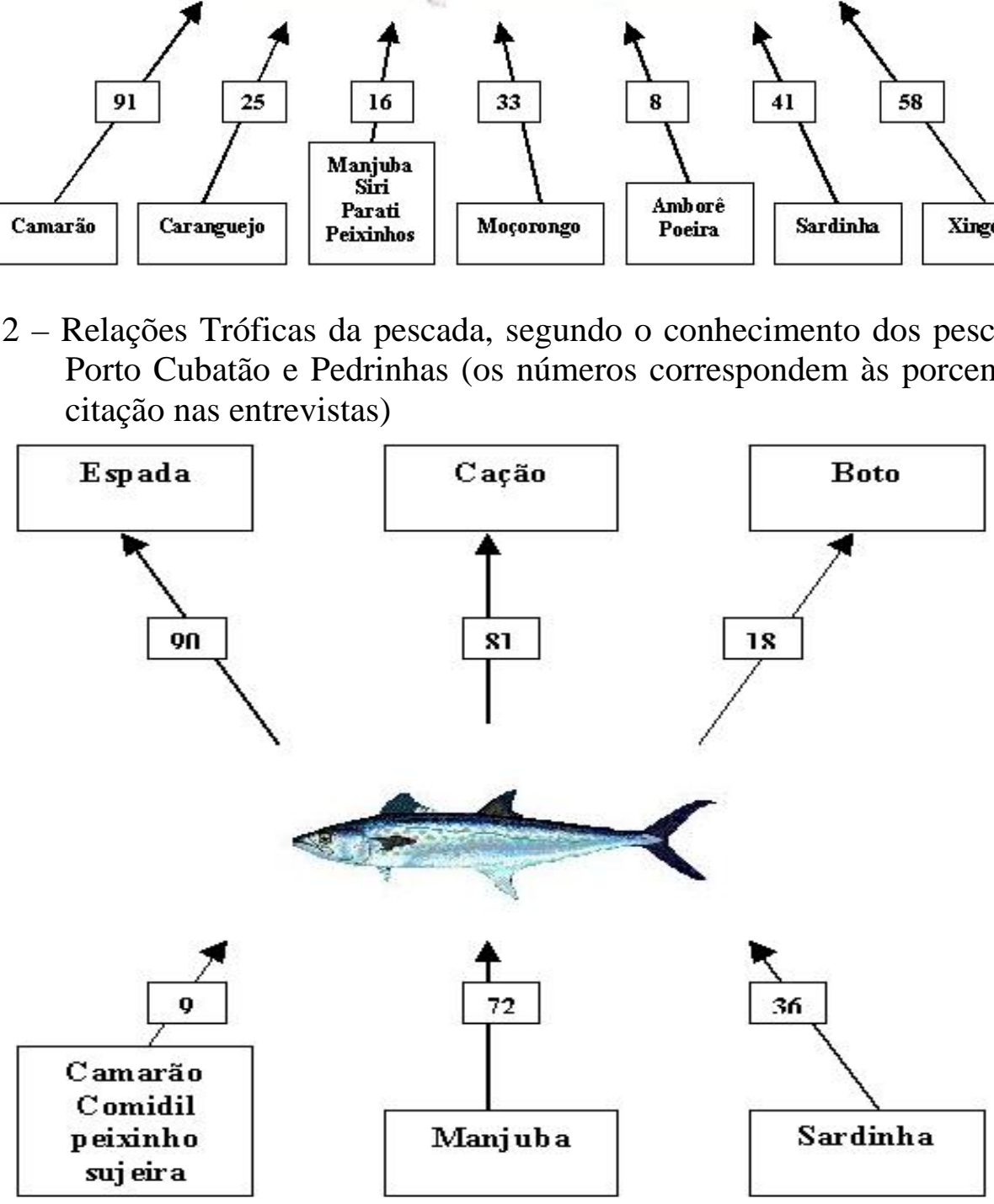

Figura 13 - Relações Tróficas da sororoca, segundo o conhecimento dos pescadores do Carijo (os números correspondem às porcentagens de citação nas entrevistas) 
Camarão, xingó, sardinha, moçorongo, caranguejo, parati, manjuba, siri, poeira e peixes pequenos foram os itens alimentares citados pelos pescadores de Porto Cubatão e Pedrinhas para a pescada. Os predadores citados foram: a espada, o cação, a caranha, o boto, o mero e o robalo (Figura 12).

De acordo com os pescadores do Carijo, a sororoca se alimenta de diversos itens alimentares, no entanto os mais citados foram a manjuba e a sardinha. Os principais predadores da sororoca são a espada e o cação (Figura 13).

O conhecimento de comunidades caiçaras em relação a alimentação e à predação, decorre também, além do que lhes é transmitido por outras gerações, de experiências do cotidiano. Os pescadores podem observar comportamentos característicos de cada espécie, como por exemplo, os casos em que outros peixes atacam os peixes que estão capturados nas redes. Eles observam também o tipo de alimentação das espécies de acordo com o que encontram nos estômagos das espécies que capturam.

As respostas dos pescadores sobre a alimentação dos peixes mostraram-se semelhantes às informações contidas em obras de literatura científica. Paz \& Begossi (1996), também afirmam a existência de uma concordância entre o conhecimento dos pescadores de Gamboa (RJ), sobre a ecologia e comportamento dos peixes com a literatura científica. Costa-Neto \& Marques (2000a), num trabalho realizado com os pescadores de Siribinha (BA), também afirmam que o conhecimento ecológico referente à ecologia trófica é compatível com o conhecimento ictiológico acadêmico.

\section{Técnicas de Captura}

Os pescadores demonstraram um conhecimento bem específico em relação às técnicas de pesca utilizadas para a captura das espécies de peixes pelo qual foram questionados. A Tabela 12 mostra as espécies e as respectivas técnicas utilizadas.

Os modos de explorar o ambiente aquático, visando espécies diferentes e utilizando tecnologias variadas são o reflexo do conhecimento local sobre a heterogeneidade ambiental do estuário e da região do Vale do Ribeira de forma geral. Os pescadores diferenciam os métodos de pesca que são geralmente utilizados para a captura de diversas espécies de peixes (Tabela 4), dos métodos utilizados para espécies, 
ambientes e épocas específicas de algumas pescarias. Por isso, verificou-se a importância de se conhecer as diferentes técnicas utilizadas pelos pescadores para a captura das espécies determinadas para o levantamento etnoictiológico (Tabela 12).

Tabela 12. Técnicas de pesca mais utilizadas para a captura das espécies de acordo com o conhecimento dos pescadores. Os números correspondem à porcentagem de citação nas entrevistas

\begin{tabular}{|c|c|c|c|c|c|}
\hline \multirow[t]{2}{*}{ Espécies } & \multicolumn{5}{|c|}{ Técnicas de pesca } \\
\hline & $\begin{array}{c}\text { Barra do } \\
\text { Ribeira } \\
(n=19)\end{array}$ & $\begin{array}{l}\text { Jairê } \\
(n=9)\end{array}$ & $\begin{array}{l}\text { Carijo } \\
(n=36)\end{array}$ & $\begin{array}{l}\text { Porto Cubatão } \\
\qquad(\mathrm{n}=\mathbf{3 4})\end{array}$ & $\begin{array}{l}\text { Pedrinhas } \\
\quad(n=24)\end{array}$ \\
\hline \multirow[t]{3}{*}{ Robalo } & Rede de espera & - & - & Rede de espera 100 & Rede de espera \\
\hline & 33,33 & - & - & tarrafa 11,11 & 71,43 \\
\hline & tarrafa 33,33 & - & - & vara 66,66 & vara 85,71 \\
\hline Totais (n) & 3 & - & - & 9 & 7 \\
\hline \multirow[t]{4}{*}{ Manjuba } & Corrico 71,43 & Arrastão 100 & - & - & - \\
\hline & rede de espera & corrico 88,88 & - & - & - \\
\hline & 35,71 & & - & - & - \\
\hline & arrastão 21,43 & & - & - & - \\
\hline Totais (n) & 14 & 9 & - & - & - \\
\hline \multirow[t]{5}{*}{ Tainha } & Rede de espera & - & Rede de espera & Rede de espera 100 & Rede de espera \\
\hline & 100 & - & 84,61 & Cerco 30 & 83,33 \\
\hline & caceio 100 & - & cerco 53,85 & & сеrсо 33,33 \\
\hline & & - & caceio 7,69 & & lanço 16,66 \\
\hline & & - & picaré 7,69 & & \\
\hline Totais (n) & 2 & - & 13 & 10 & 6 \\
\hline \multirow[t]{5}{*}{ Parati } & - & - & Rede de espera & Rede de espera 100 & Rede de espera \\
\hline & - & - & 75 & cerco 12,5 & 83,33 \\
\hline & - & - & cerco 25 & tarrafa 15,5 & lanço 16,66 \\
\hline & - & - & lanço 25 & & picaré 16,66 \\
\hline & - & - & tarrafa 8,33 & & tarrafa 16,66 \\
\hline Totais (n) & - & - & 12 & 8 & 6 \\
\hline \multirow[t]{3}{*}{ Pescada } & - & - & - & Rede de espera 100 & Rede de espera \\
\hline & - & - & - & vara 57,14 & 100 \\
\hline & - & - & - & & vara 80 \\
\hline Totais (n) & - & - & - & 7 & 5 \\
\hline \multirow[t]{5}{*}{ Sororoca } & - & - & Rede de espera & - & - \\
\hline & - & - & 90,90 & - & - \\
\hline & - & - & lanço 27,27 & - & - \\
\hline & - & - & caceio 18,18 & - & - \\
\hline & - & - & cerco 9,09 & - & - \\
\hline Totais (n) & - & - & 11 & - & - \\
\hline
\end{tabular}

As tecnologias de pesca utilizadas pelos pescadores artesanais refletem a forma e a intensidade como os estoques pesqueiros são explorados, pois muitas vezes, o 
modelo tradicional de exploração adotado por determinada comunidade pode culminar com a conservação dos recursos pesqueiros. Além do que, o estudo do comportamento humano e sua relação com o ambiente, através da utilização dos recursos naturais, entendendo suas estratégias e decisões, permitem que os resultados provenientes destes estudos e de estudos de ecologia humana de forma geral possam ser aplicados ao desenvolvimento de políticas de manejo e co-manejo (Lopes, 2004).

Neste contexto, a crise no setor pesqueiro é de escala mundial e não se restringe à pesca industrial, interferindo, muitas vezes, na pesca de pequena escala, realizada por comunidades de pescadores artesanais. Como alternativa a estes problemas inúmeros países vêm enfrentando essa situação desenvolvendo estratégias de gestão participativa visando compreender a forma como os recursos pesqueiros são explorados através do estudo sobre os métodos de pesca, o volume capturado, a definição de épocas de defeso e sobretudo a proteção dos ecossistemas propícios a reprodução e recrutamento dos organismos marinhos, incluindo a auto-regulação das atividades de exploração (Nogara, 2000; Berkes, 1985; Lopes, 2004). Dessa forma, também se faz importante a análise do conhecimento dos pescadores acerca das épocas de captura e de reprodução das espécies de peixes, com o intuito de tornar este conhecimento subsídio para uma gestão participativa dos recursos pesqueiros.

\section{Sazonalidade}

Os pescadores diferenciam as épocas do ano em: verão (outubro a março, aproximadamente) e inverno (abril a setembro, aproximadamente). Então, em relação à sazonalidade de captura dos peixes, existem os peixes de safra de verão, os peixes de safra de inverno e os peixes de ano todo, ou seja, aqueles que podem ser capturados em qualquer época do ano. Embora estas épocas sejam assim observadas pela maioria dos pescadores, a opinião em relação às safras dos peixes mostrou-se variada. A Figura 14 mostra esta diversidade de opiniões sobre a sazonalidade das espécies. 


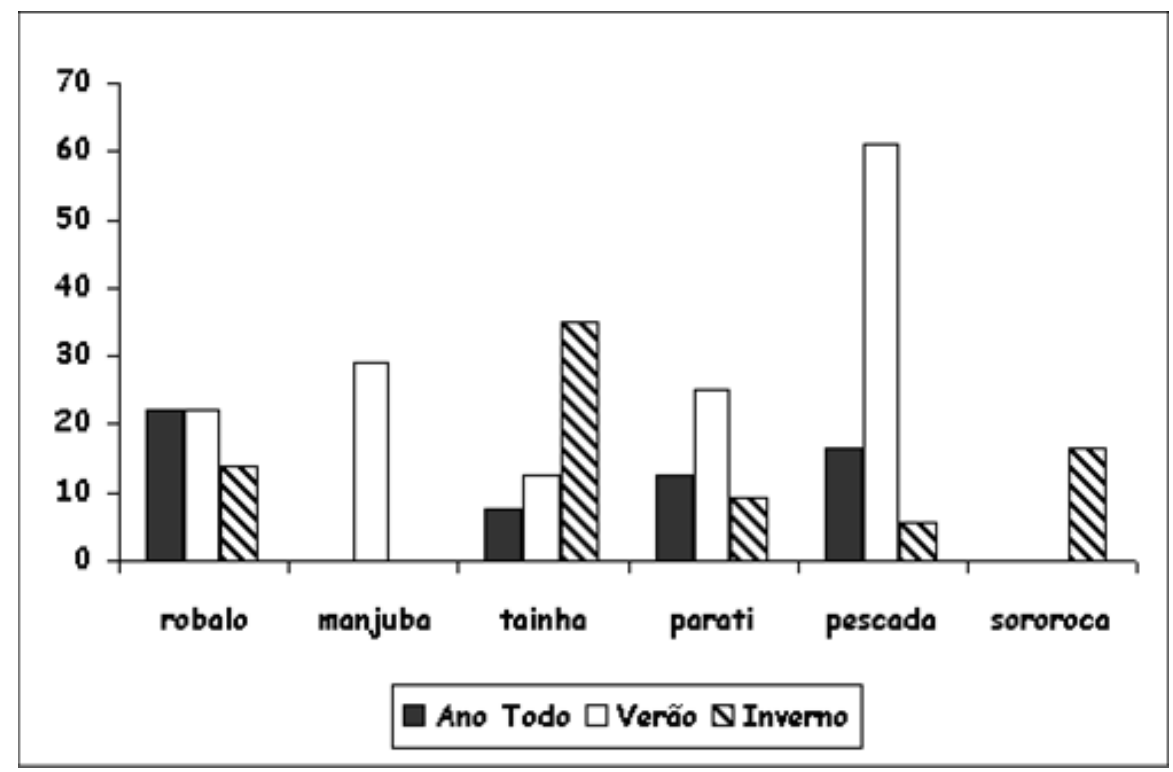

Figura 14 - Sazonalidade das espécies, segundo o conhecimento dos pescadores artesanais (\% de citação nas entrevistas)

Costa-Neto \& Marques (2000b), analisaram o conhecimento tradicional sobre aspectos relacionados à distribuição temporal espacial de recursos pesqueiros em Conde (BA) e verificaram que lá os pescadores também entendem o “inverno” e o "verão” como as duas principais estações do ano, interferindo tanto nas atividades de pesca, quanto na abundância e distribuição espacial e temporal dos recursos. Neste último caso, a interferência pode se dar tanto nas características intrínsecas das espécies, como período reprodutivo, ou nas respostas comportamentais a estímulos ambientais. Segundo os autores, o conhecimento dos pescadores sobre a sazonalidade dos peixes dá-se também através de associações com fenômenos meteorológicos (tempestades, chuvas) e fenômenos cósmicos (ciclo lunar, marés).

\section{Reprodução}

Os pescadores associam a época de reprodução com o comportamento de desova, ou seja, as épocas em que são observados os peixes “ovados”, segundo eles, são as épocas em que estão “desovando” e “procriando”, portanto se reproduzindo. Diferente das épocas de safra, os pescadores foram mais específicos quanto à época de reprodução, 
pois citaram os meses em que os peixes estão se reproduzindo. Algumas opiniões mostraram-se diversificadas em relação aos meses exatos em que se reproduzem os peixes, enquanto que em outras se pôde verificar um padrão nas citações de diferentes comunidades, conforme mostra a Figura 15.

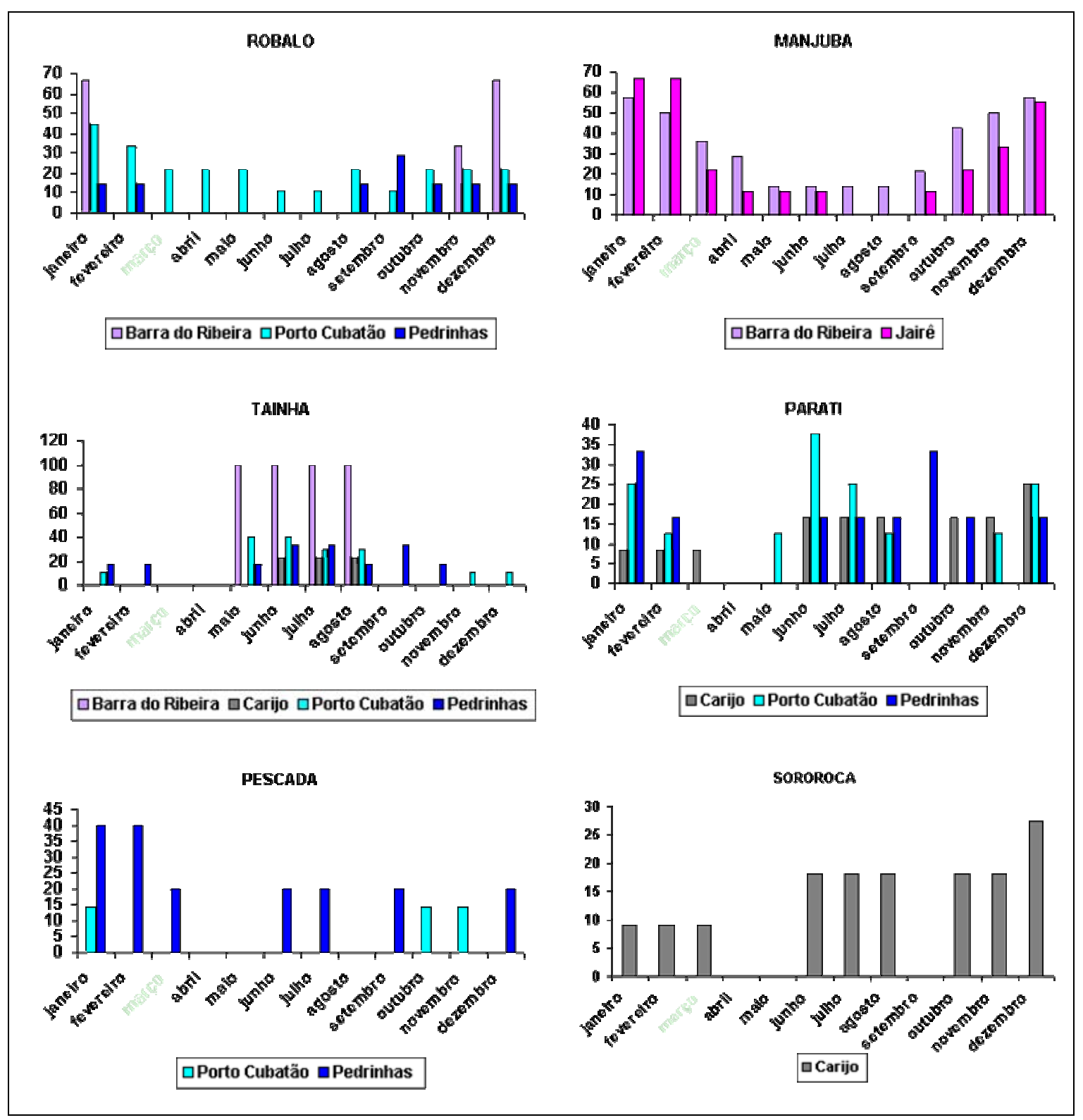

Figura 15 - Períodos de reprodução das espécies de peixes segundo o conhecimento dos pescadores (\% de citação nas entrevistas) 
No caso do robalo, houve uma predominância de citações no intervalo entre os meses de setembro a fevereiro, segundo os pescadores da Barra do Ribeira, Porto Cubatão e Pedrinhas. Já para a manjuba, pode-se verificar, segundo os pescadores da Barra do Ribeira e Jairê um intervalo entre os meses de outubro a março. Em relação a tainha a predominância de citação ocorreu na época de inverno, ou seja, entre os meses de maio a agosto, segundo os pescadores da Barra do Ribeira, Carijo, Porto Cubatão e Pedrinhas.

Silvano \& Begossi (2002), num estudo realizado com os pescadores do Rio Piracicaba (SP), mostraram que dentre vários aspectos de etnoecologia (dieta, habitat, migração, predação, sazonalidade e reprodução), os pescadores apresentaram mais dúvidas em relação à reprodução dos peixes do que em relação aos demais aspectos. Os autores ainda apontam para o fato de que os pescadores demonstram um conhecimento mais detalhado em relação a espécies de peixes mais abundantes e mais úteis, especialmente as mais valiosas comercialmente e também conhecem mais sobre os peixes nativos da região do que de espécies exóticas introduzidas no ecossistema.

Comparar o conhecimento local com o cientifico tem importância óbvia, na medida em que pode trazer novos conhecimentos e descobertas (Diamond, 1985) ${ }^{8}$, facilitando os passos convencionais da ciência. Além disso, esta é uma das formas de se resgatar parte do conhecimento que se perde dia após dia, em função da desvalorização da cultura tradicional (Lopes, 2004).

No entanto resta ainda uma lacuna a ser preenchida, justamente a que permite entender como se dá a percepção humana sobre o mundo natural, no que diz respeito aos mitos, crenças, tabus e outros aspectos que fazem parte das diferentes culturas. Tais aspectos representam não só a forma como as populações exploram os recursos naturais, como também os significados que os recursos possuem. Além disso, podem complementar estudos sobre as interações entre as populações humanas e o ambiente, indo além de uma análise utilitarista.

\footnotetext{
${ }^{8}$ Diamond, J. 1985. Stinking birds and burning books. Natural History 94 (2): 5-12. Citado por Lopes, 2004.
} 


\subsection{A Pesca Esportiva no Vale do Ribeira}

Além da pesca artesanal, existe na região do complexo estuarino lagunar de Cananéia-Iguape-Ilha Comprida, a pesca amadora (chamada neste trabalho de pesca esportiva) desenvolvida por turistas (Mendonça \& Katsuragawa, 2001). Segundo Dias Neto \& Dornelles (1996), a pesca esportiva é praticada em toda a costa brasileira, com a finalidade de turismo, lazer ou desporto.

Neste trabalho, a pesca esportiva foi analisada, primeiramente, com o objetivo de caracterização desta como atividade econômica praticada pelos turistas que freqüentam as comunidades caiçaras do Vale do Ribeira e posteriormente com o intuito de traçar as relações que esta atividade tem apresentado com os pescadores e de forma geral com a atividade de pesca artesanal da região.

Foram entrevistados 74 grupos de pescadores esportivos, nas comunidades da Barra do Ribeira (Iguape, $\mathrm{N}=62$ ), Porto Cubatão (Cananéia, $\mathrm{N}=8$ ) e Pedrinhas (Ilha Comprida, $\mathrm{N}=4$ ).

\section{O Perfil dos Pescadores Esportivos}

Com as informações sócio-econômicas obtidas nas entrevistas, pode-se traçar o perfil dos pescadores esportivos, em que a idade média foi de 43,38 anos na Barra do Ribeira, 48,25 anos em Porto Cubatão e 33,75 anos em Pedrinhas. Em relação ao sexo do entrevistado, na Barra do Ribeira 85,48\% são homens e 14,52\% mulheres; em Porto Cubatão 87,5\% são homens e 12,5\% mulheres e em Pedrinhas 75\% homens e 25\% mulheres. Na Barra do Ribeira, devido ao fato de ter sido realizado um maior número de entrevistas, o grau de escolaridade dos informantes mostrou-se mais diversificado, enquanto em Porto Cubatão, 87,5\% possuíam o ensino superior completo e 12,5\% o ensino superior incompleto e em Pedrinhas 50\% possuíam o ensino médio completo e 25\% o ensino fundamental, conforme mostra a Tabela 13.

A média do número de integrantes (pescadores esportivos) nos grupos entrevistados foi de 2,1 pescadores na Barra do Ribeira, 2,5 pescadores em Porto Cubatão e 3,75 pescadores em Pedrinhas. 
A maioria dos informantes da Barra do Ribeira (67,74\%) e de Pedrinhas (100\%) não possuía documentos de pesca esportiva. A licença de pesca é obrigatória para pescadores amadores (esportivos) e profissionais, tanto em águas interiores, nos rios, riachos, represas e lagos, como no mar (Soares, 2001). No entanto, Porto Cubatão foi a comunidade onde um maior número de pescadores possuía o documento de pesca (37,5\%). Este fato difere das demais comunidades em razão desta possuir infraestrutura mais especializada para a pesca esportiva, o que gera mais informação e atrai turistas com o objetivo da pesca.

Tabela 13. Perfil dos pescadores esportivos entrevistados

\begin{tabular}{|c|c|c|c|}
\hline & $\begin{array}{c}\text { Barra do Ribeira } \\
(n=62)\end{array}$ & $\begin{array}{c}\text { Porto Cubatão } \\
(\mathrm{n}=8)\end{array}$ & $\begin{array}{c}\text { Pedrinhas } \\
(\mathrm{n}=4)\end{array}$ \\
\hline \multicolumn{4}{|l|}{ Faixa Etária } \\
\hline Média & 43,38 & 48,25 & 33,75 \\
\hline Mínima & 18 & 17 & 30 \\
\hline Máxima & 74 & 72 & 38 \\
\hline Desvio padrão & 13,62 & 17,11 & 3,5 \\
\hline \multicolumn{4}{|l|}{ Sexo $(\%)$} \\
\hline Masculino & 85,48 & 87,5 & 75 \\
\hline Feminino & 14,52 & 12,5 & 25 \\
\hline \multicolumn{4}{|l|}{ Escolaridade \% } \\
\hline Fundamental incompleto & 6,45 & - & - \\
\hline Fundamental completo & 22,58 & - & 25 \\
\hline Médio incompleto & 12,9 & - & - \\
\hline Médio completo & 24,19 & - & 50 \\
\hline Superior incompleto & 9,68 & 12,5 & - \\
\hline Superior completo & 20,97 & 87,5 & - \\
\hline Analfabeto & 3,22 & - & - \\
\hline \multicolumn{4}{|l|}{ N de pescadores no grupo } \\
\hline Média & 2,1 & 2,5 & 3,75 \\
\hline Mínima & 1 & 1 & 3 \\
\hline Máxima & 6 & 4 & 4 \\
\hline Desvio padrão & 1,05 & 1,12 & 0,5 \\
\hline \multicolumn{4}{|l|}{ Documentos de pesca (\%) } \\
\hline Nenhum & 67,74 & 50 & 100 \\
\hline Pescador esportivo & 25,81 & 37,5 & - \\
\hline Pescador profissional & 4,84 & - & - \\
\hline Piloto de barco & 1,61 & - & - \\
\hline $\begin{array}{l}\text { Localidade dos informantes } \\
\text { (acima de 5\%) }\end{array}$ & $\begin{array}{l}\text { São Paulo 58,06 } \\
\text { Iguape } 11,29\end{array}$ & $\begin{array}{c}\text { São Paulo } 25 \\
\text { Curitiba 37,5 } \\
\text { Paraná 25 } \\
\text { São Roque 12,5 }\end{array}$ & $\begin{array}{l}\text { São Paulo } 50 \\
\text { São Bernardo do } \\
\text { Campo } 50\end{array}$ \\
\hline
\end{tabular}


Os informantes eram oriundos de diversas localidades, porém a maioria dos entrevistados na Barra do Ribeira era da cidade de São Paulo. Em Porto Cubatão o maior número de entrevistados era de Curitiba (37,5\%), enquanto que em Pedrinhas, 50\% era da cidade de São Paulo e 50\% de São Bernardo do Campo.

\section{Freqüência das Pescarias Esportivas e Tipo de Hospedagem Utilizada}

Os pescadores esportivos entrevistados freqüentam as comunidades para a prática da pesca esportiva, em sua maioria, nos períodos de férias, que normalmente correspondem ao verão (Figura 16).

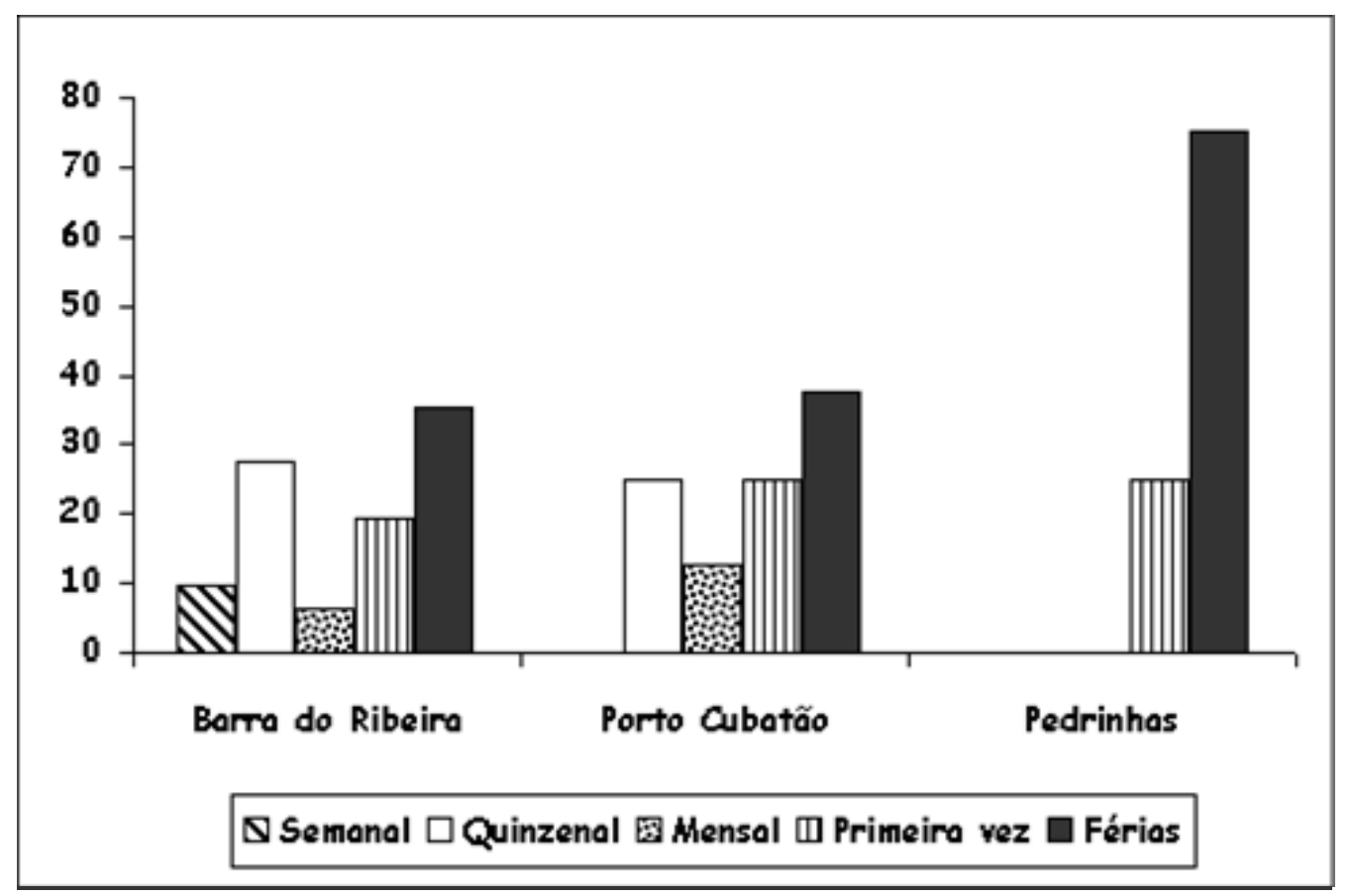

Figura 16 - Freqüências das pescarias esportivas

Um aspecto importante relacionado à pesca esportiva é a infraestrutura que as comunidades oferecem aos pescadores e turistas de forma geral. A maioria dos pescadores entrevistados na Barra do Ribeira fica hospedada em suas próprias casas de veraneio na região ou em pousadas, enquanto que em Pedrinhas o principal tipo de hospedagem são casas alugadas e em Porto Cubatão são as próprias residências e os 
clubes de pesca (Figura 17). Porto Cubatão é a comunidade onde se pode observar um maior número de clubes de pesca e também outros tipos de serviços para a pesca esportiva.

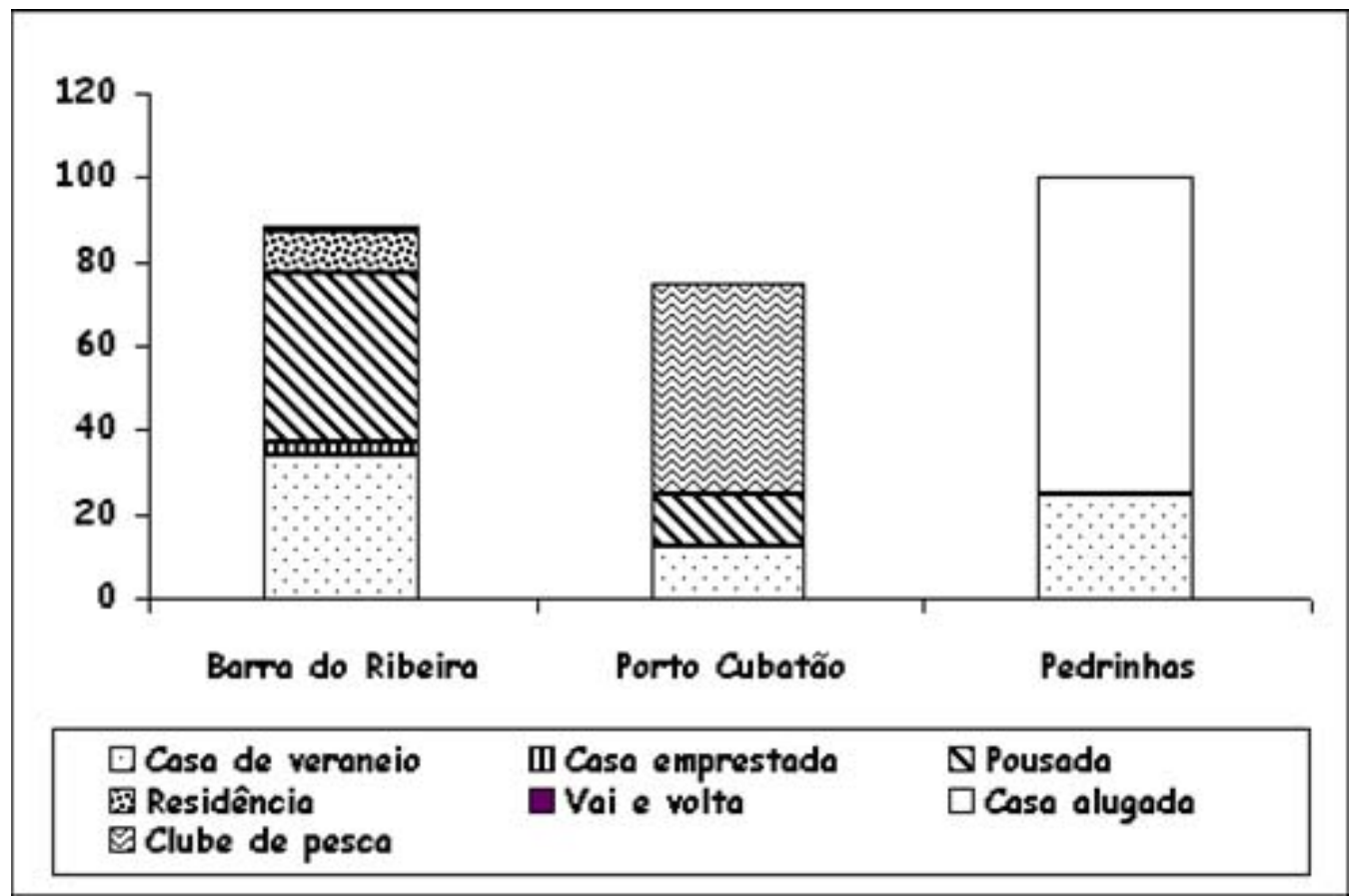

Figura 17 - Tipo de hospedagem utilizada pelos pescadores esportivos

\section{As Espécies Preferidas}

Os pescadores esportivos foram questionados quanto às espécies de peixes de maior interesse para captura. Dessa forma pode-se confeccionar um ranking das principais espécies. De acordo com este ranking (Tabela 14), o robalo é a espécie mais procurada nas comunidades da Barra do Ribeira e Pedrinhas, enquanto que em Porto Cubatão esta apareceu em segundo lugar na preferência dos pescadores. A pescada foi também uma espécie citada nas três comunidades, porém com preferências diferenciadas.

O robalo é uma espécie carnívora muito procurada pelo pescador esportivo, o que faz com que haja uma grande ligação de suas capturas com uma outra atividade 
pesqueira importante na região, que é a pesca de exemplares juvenis de camarão branco (Litopenaeus schimitti) (Mendonça \& Katsuragawa, 2001).

Tabela 14. Ranking das espécies mais procuradas pelos pescadores esportivos (de acordo com a citação, \%)

\begin{tabular}{|c|c|c|c|}
\hline Ranking & Barra do Ribeira & Porto Cubatão & Pedrinhas \\
\hline $1^{\mathrm{a}}$ & Robalo 85,48 \% & Pescada 62,5 \% & Robalo $100 \%$ \\
\hline $2^{a}$ & Pampo 17,74 \% & Robalo $50 \%$ & Pescada 75 \% \\
\hline $3^{a}$ & Bagre $16,13 \%$ & Anchova $25 \%$ & $\begin{array}{l}\text { Bagre 25\% } \\
\text { Corvina 25\% }\end{array}$ \\
\hline $4^{a}$ & Corvina $12,90 \%$ & $\begin{array}{l}\text { Cavala 12,5 \% } \\
\text { Bicuda 12,5 \% }\end{array}$ & \\
\hline $5^{a}$ & $\begin{array}{l}\text { Pescada 11,29 \% } \\
\text { Xaréu 11,29 \% }\end{array}$ & & \\
\hline
\end{tabular}

\section{Comércio de Iscas Naturais}

A atividade de comércio de iscas naturais tem sido muito praticada pelas comunidades caiçaras da região. Em todos os municípios analisados neste estudo, grande parte dos pescadores artesanais desenvolve a atividade de venda de iscas naturais como forma de complementar a renda. No entanto, não existem dados sobre o número de pescadores que atuam com essa modalidade ou sobre a produção, devido à grande extensão do sistema estuarino lagunar e à variação sazonal com que é praticada (Mendonça \& Katsuragawa, 2001).

Dada a importância observada, da atividade de coleta de iscas naturais nas comunidades estudadas, alguns pescadores foram entrevistados sobre a mesma com o intuito de compreender a pratica desta e sua relação com a pesca esportiva.

Além disso, os pescadores entrevistados também desenvolvem paralelamente à pesca artesanal e ao comércio de iscas, atividades como “piloteiro” (são contratados para levar os pescadores esportivos até os pesqueiros), caseiro, pedreiro, coletor de ostra, entre outras.

As espécies comercializadas como iscas naturais são o camarão branco, o emborê, o pitu, o corte de faca, o corrupto, o moçorongo, a tuvira e a manjuba. Os preços e as técnicas utilizadas variam de acordo com a espécie, conforme mostra a Tabela 15. 
Tabela 15. Espécies de iscas naturais, técnicas de coleta e preço (R\$)(agosto 2003)

\begin{tabular}{|c|c|c|}
\hline Espécies & Técnica de coleta & RS \\
\hline Camarão branco & $\begin{array}{l}\text { Gerival } \\
\text { Arrasto } \\
\text { Tarrafa } \\
\text { Puçá }\end{array}$ & 0,15 a 0,50 cada \\
\hline Emborê & $\begin{array}{l}\text { Puçá } \\
\text { Arrasto } \\
\text { Peneira }\end{array}$ & 0,80 a 1,00 cada \\
\hline Pitu & $\begin{array}{l}\text { Peneira } \\
\text { Puçá } \\
\text { Tarrafa }\end{array}$ & 0,15 a 0,25 cada \\
\hline Corte de faca & $\begin{array}{l}\text { Peneira } \\
\text { Puçá } \\
\text { Arrasto }\end{array}$ & 1,00 cada \\
\hline Sardinha & Arrasto & Depende da safra \\
\hline Corrupto & Bomba de sucção & 10,00 (o balde) \\
\hline Moçorongo & Mão & 0,50 a 1,00 cada \\
\hline Manjuba & $\begin{array}{l}\text { Corrico } \\
\text { Rede de manjuba }\end{array}$ & Depende da safra, em média de 1,50 a 2,00 o Kg \\
\hline Tuvira & $\begin{array}{l}\text { Peneira } \\
\text { Puçá }\end{array}$ & 0,80 cada \\
\hline
\end{tabular}

Destas, o camarão branco (juvenis) é a mais capturada e conseqüentemente mais comercializada pelos pescadores. As demais são menos procuradas pelos pescadores esportivos.

Com o aumento desta atividade, estudos têm sido realizados e diversos autores apontam para a importância desta atividade para as comunidades locais e também para a necessidade de estudo sobre a biologia desta espécie.

De acordo com Mendonça \& Katsuragawa (2001), os juvenis de camarão branco são capturados através de gerival e utilizados como isca viva, não só para a captura de robalos como também para as demais espécies capturadas pelos pescadores esportivos. Este fato dificulta a estatística deste camarão, pois não existem desembarques comerciais deste e a venda do produto ocorre na área de captura ou nas moradias dos próprios pescadores, além de a venda do produto ser realizada em número de peças (unidade) e não em quilos. 
Esta pesca ocorre principalmente durante o período de fevereiro e abril. Estimase que neste período (safra) e nos períodos de maior amplitude da maré (lua cheia ou nova) atuem em torno de 100 pescadores "por maré” no complexo estuarino lagunar de Iguape-Cananéia-Ilha Comprida. Como a pesca de gerival depende da corrente da maré, ao longo do dia os pescadores pescam na “corrida da maré” de enchente e de vazante, num sistema de arrasto passivo. Este número varia com a entrada de turistas aos fins de semana, chegando, muitas vezes a dobrar. Tem-se observado que atualmente muitos pescadores utilizam motores de popa para arrastar, aumentando muito o poder de captura e acarretando sérios riscos para a manutenção do recurso (Mendonça \& Katsuragawa, 2001).

A sardinha e a manjuba são comercializadas por quilo e não precisam ser mantidas vivas. Já as demais espécies necessitam ser mantidas em viveiro para que se mantenham vivas para a comercialização. Estes viveiros são confeccionados com tambores de plástico perfurados e mantidos submersos nos rios ou estuários. As iscas são mantidas nestes viveiros até a hora da comercialização. Este tempo pode chegar até cerca de uma semana, de acordo com a espécie em questão. Não há nenhum cuidado em especial com a conservação das iscas nos viveiros. Segundo os pescadores, como os tambores são perfurados, as iscas têm acesso à água e alimentação de que precisam para permanecer vivas.

\section{Considerações sobre a Pesca Esportiva ${ }^{9}$}

A pesca esportiva é uma das características do turismo da região, o que definitivamente movimenta a maioria das comunidades caiçaras. Porém, este fato não é uma constatação exclusiva deste estudo. Outras comunidades caiçaras também têm cada vez mais deixado a pesca e outras atividades para sobreviverem às custas do turismo e dessa forma estão encontrando uma fonte importante de renda na pesca esportiva.

Ribaric (1997), observou numa comunidade do Litoral Sul, a Barra do Subaúma, localizada entre os municípios de Iguape e Cananéia, uma crescente expansão do turismo, onde os pescadores principalmente, no período entre novembro e março, 
atendem de várias maneiras aos turistas, seja alugando seus barcos, seja como guias de pesca ou vendendo camarões vivos para servirem de iscas para os pescadores esportivos que visitam a região.

Plante \& Breton (1997), num trabalho realizado em Trindade (RJ), mostram que os pescadores artesanais chegam até a modificar o ciclo temporal da pesca artesanal, que entra em competição com a pesca esportiva. Segundo estes autores, outros fatores também atrapalham a pesca artesanal, como por exemplo, a invasão dos turistas em praias que servem aos moradores para a pesca de tarrafas. Os moradores reclamam que os turistas ficam na praia até o amanhecer. As luminárias dos campings refletem sobre o mar, o que assusta os peixes, que desviam sua rota, evitando a costa de praias e impossibilitando a utilização de certas técnicas de pesca e pontos de exploração.

Silvano (1997), em seu trabalho realizado em três comunidades de pescadores do Rio Piracicaba, no interior de São Paulo, aponta aspectos positivos e negativos observados em relação ao turismo naquela região. Entre os aspectos positivos do turismo encontram-se, da mesma forma que no Vale do Ribeira, aluguel de barcos para a pesca, compra de peixes, comercialização de produtos de mercearia e prestação de serviço em casas de veraneio, responsáveis por um aumento na renda dessas comunidades. Entre os aspectos prejudiciais encontra-se a pesca efetuada pelos turistas, os quais utilizam malhagens de redes proibidas e competem com o pescador artesanal.

A relação dos pescadores esportivos com os moradores das comunidades estudadas é benéfica e durante a realização deste trabalho não foi mencionado nenhum caso de conflito entre moradores e pescadores esportivos, diferente do que podemos verificar em outros trabalhos sobre a pesca esportiva. Castro \& Begossi (1996) analisaram a pesca esportiva no Rio Grande, entre os Estados de São Paulo e Minas Gerais. Segundo estes autores, o turismo é considerado o segundo maior problema relacionado à pesca artesanal, precedido apenas pela Usina Hidrelétrica construída na região. As técnicas de pesca utilizadas são diferentes. Os conflitos ocorrem em relação aos locais de pesca que em épocas de transição entre seca e chuva são explorados pelos dois grupos de pescadores. No Litoral Sul e Vale do Ribeira, as épocas de maior

\footnotetext{
${ }^{9}$ Parte destas considerações já foram observadas em estudo (Ramires e Barrella, 2001b) realizado anteriormente.
} 
atividade da pesca esportiva também coincidem com a época de maior atividade da pesca artesanal, porém não há conflitos, pois além dos dois grupos utilizarem técnicas e locais diferentes, a maioria dos pescadores artesanais das comunidades deixam de praticar a pesca artesanal para prestarem serviços como guias e piloteiros, venda de iscas etc., aos pescadores esportivos, não havendo assim conflitos por exploração de recursos.

Berkes (1984) fez uma análise ecológica da competição entre pescadores artesanais e esportivos. Este autor afirma que conflitos entre esses grupos são reais em épocas e áreas onde as atividades acontecem simultaneamente. Embora a competição entre pescadores artesanais e esportivos, especialmente em águas interiores e áreas costeiras possa prover uma análise ecológica de competição por recursos, o autor aponta para o fato de que este tipo de competição mostra-se mais cultural do que ecológica, o que na maioria das vezes gera conflitos. No caso do Litoral Sul e Vale do Ribeira, a pesca artesanal cada vez mais tem cedido lugar à pesca esportiva. Raras são as épocas em que se pode verificar as duas sendo praticadas simultaneamente e este fato contribui para a ausência de conflitos culturais e competições ecológicas por uso de recursos. Os pescadores esportivos são muito bem recebidos por todas as comunidades estudadas. Essa boa aceitação do turismo pelos moradores deve-se ao fato de que o turismo proporciona uma maior fonte de renda para as famílias caiçaras, proporcionando melhoria da qualidade de vida.

O crescimento da pesca esportiva tem sido expressivo em muitos países. Porém, esta precisa ser vista como um segmento da economia que gera recursos, empregos e melhoria na qualidade de vida, tanto de quem pratica como de quem depende desta atividade para complementação da renda, como no caso das comunidades caiçaras.

Hoje se faz necessária uma política moderna para o setor. Se bem conduzida, a pesca esportiva no Brasil movimentará cada vez mais recursos, além de contribuir para a conservação do ambiente (Prado, 1999). Em função disto, parece indispensável um melhor acompanhamento técnico-científico dessa atividade, além de um processo de ordenamento voltado para a sua expansão, comprometido com o uso sustentável dos recursos e com a eliminação de potenciais conflitos entre os diferentes usuários dos recursos pesqueiros (Dias Neto \& Dornelles, 1996). 


\section{CONCLUSÕES}

A pesca artesanal ainda tem importância como uma das principais fontes de renda para as cinco comunidades estudadas neste trabalho. Mesmo em Pedrinhas, onde para a maioria dos entrevistados ela representa uma fonte parcial de renda, ainda é praticada diariamente.

A prática diária da pesca artesanal mostra que a atividade ainda está fortemente presente no cotidiano das comunidades caiçaras. No entanto, uma grande diversidade de outras atividades econômicas foram observadas, mostrando a necessidade dos pescadores em complementar a renda. Isto indica que a pesca artesanal já não tem mais condições de ser a única fonte de renda das famílias caiçaras.

A comunidade da Barra do Ribeira apresentou uma maior diversidade de métodos e pontos de pesca. A rede de espera foi o método mais utilizado na região por ser possível o seu uso em ambientes diversos.

A pesca da manjuba representa uma importante característica da peca artesanal da região de Iguape. As comunidades da Barra do Ribeira e do Jairê ainda se dedicam a esta prática na época de safra.

Os pescadores atribuem o sucesso das pescarias à influência de variáveis como fases da lua, maré, chuva. Todavia, as opiniões não foram consensuais, impossibilitando a definição sobre quais destas variáveis ou qual a combinação delas é mais importante para a pesca, segundo o conhecimento dos pescadores. É possível que isso se deva às diferenças entre os locais de pesca de cada grupo. Ou seja, cada conjunto de informações corresponderia especificamente às características do (s) ponto (o) de pesca.

Os pescadores também avaliam a qualidade ambiental da região para a prática da pesca artesanal. Segundo eles, a região é uma das mais ricas em diversidade de peixes e ambientes conservados. Entretanto, em relação à situação atual, comparada aos anos 
anteriores, as opiniões foram unânimes em considerar que, nas últimas décadas houveum decréscimo em relação à quantidade de peixes, ao comércio, ao preço dos peixes, à procura pelo pescado, entre outros aspectos.

O conhecimento ecológico dos pescadores sobre os peixes é extenso e apresenta uma elevada concordância com o conhecimento científico. De forma geral, os pescadores expressam mais informações sobre aspectos relacionados à alimentação e predação dos peixes. Foi citada pelos pescadores uma grande diversidade de itens referentes às relações tróficas dos peixes mais capturados. A reprodução dos peixes foi um aspecto onde se observou menos detalhamento e precisão nas respostas dos pescadores e a maior incidência de desconhecimento sobre o assunto.

$\mathrm{O}$ etnoconhecimento influi diretamente na atividade pesqueira e atualmente, também está sendo utilizado na prática de outras atividades que complementam a renda, como por exemplo, a coleta de iscas naturais.

Embora não tenha sido um dos objetivos específicos desta pesquisa, pode-se verificar também um extenso saber sobre a taxonomia dos peixes.

A elevada concordância entre o conhecimento dos pescadores e a literatura científica, bem como a forma com que são manejados os recursos naturais pelas comunidades caiçaras, evidenciam a crescente importância da etnobiologia e da etnoecologia para a biologia. Estas podem contribuir com o intuito da conservação biológica da natureza e também com as áreas das ciências sociais que tratam da percepção do amboiente e do modo de vida dessas populações.

A pesca artesanal no litoral paulista configura-se como um forte traço na cultura caiçara. Suas formas de resistir a diversas influências externas vem alterando a dinâmica socioeconômica das populações de pescadores nas últimas décadas.

A pesca esportiva pode ser entendida como uma dessas influências externas que vêm modificando a dinâmica socioeconômica das populações caiçaras. No entanto, a pesca esportiva tem trazido benefícios que ainda não podem ser avaliados do ponto de vista ecológico e sociocultural, pois ainda são necessários estudos sobre seus aspectos “positivos” e "negativos” na dinâmica das populações locais e estoques pesqueiros. 
Constatou-se que a pesca esportiva tem disputado recursos e espaços com a pesca artesanal. Nas três comunidades onde a pesca esportiva foi analisada, Porto Cubatão foi a que apresentou uma maior infraestrutura para a realização desta atividade, assim como o maior interesse e envolvimento dos pescadores artesanais pela pesca esportiva.

A atividade de comércio de iscas vivas tem aumentado e representa uma importante atividade para os pescadores artesanais nas comunidades de Barra do Ribeira, Porto Cubatão e Pedrinhas, além de estar totalmente relacionada com a pesca artesanal e o etnoconhecimento (há amplo emprego dos saberes tradicionais nas novas atividades).

A pesca esportiva é praticada tanto por turistas que freqüentam as comunidades com objetivos diversos, como por pescadores esportivos que chegam às comunidades com o objetivo direto de praticá-la por esporte. O crescimento desta atividade tem representado melhoria de vida para os caiçaras, no sentido em que complementa a renda familiar, que antes era obtida através de atividades de subsistência, sobretudo pela pesca e pela agricultura de subsistência.

Contudo, a pesca esportiva é uma atividade que requer organização e planejamento, para prevenir possíveis impactos sobre o ambiente. Assim, o desenvolvimento de projetos de educação ambiental com os participantes dessa atividade e os pescadores artesanais é de suma importância para a sustentabilidade dos recursos utilizados por ambos.

Este trabalho representou mais uma contribuição para a discussão das relações entre biodiversidade e diversidade cultural e sua importância. A descrição e análise do conhecimento local já foram apresentadas em trabalhos etnocientíficos anteriores.

No entanto, o que se espera é que o reconhecimento do conhecimento local passe a evidenciar o direito e a necessidade da participação das populações locais nos planos de manejo e conservação. Também espera-se que este conhecimento aponte caminhos para outros estudos que possam abordar a especificidade do conhecimento local, a potencial contribuição deste para facilitar os passos da ciência convencional e a abordagem da complexidade das relações entre as populações caiçaras, a pesca esportiva e o ambiente. 


\section{REFERÊNCIAS BIBLIOGRÁFICAS}

ADAMS, C. Caiçaras na mata Atlântica: Pesquisa versus planejamento e gestão ambiental. São Paulo: Annablume; FAPESP, 2000. 337p.

ALBUQUERQUE, U. P. Introdução. In: ALBUQUERQUE, U.P.; ALVES, A.G.C.; SILVA, A.C.B.L.; SILVA, V.A. (Org.). Atualidades em etnobiologia e etnoecologia. Recife: Sociedade Brasileira de Etnobiologia e Etnoecologia, 2002. 151p.

BANDEIRA, F.P.S. de F. Construindo uma epistemologia do conhecimento tradicional: problemas e perspectivas. In: ENCONTRO BAIANO DE ETNOECOLOGIA E ETNOBIOLOGIA, Feira de Santana. 2001, Anais. Feira de Santana: Sociedade Brasileira de Etnobiologia e Etnoecologia, 2001. p.109-133.

BAILEY, K.D. Methods of social research. New York: McMillan Publishers, The free press, 1982. 553p.

BEGOSSI, A. Fishing Actives and Strategies at Búgios Island (Brazil). In: MEYER, R.M.; ZHANG, C.; WINDSOR, M.L.; McCAY, B.J.; HUSHAK, L.J.; MUTH, R.M. (Ed.) Fisheries resource utilization and policy. Athens, Greace, 1992. 125-141p.

BEGOSSI, A. Ecologia humana: um enfoque das relações homem-ambiente. Interciencia, v.18, n.3, p.121-132, 1993.

BEGOSSI, A. Fishing sport and sea tunere: incipient forms of local manegement in atlantic forest coastal communities. Human Ecology, v.23, n.3, p.387-406, 1995.

BEGOSSI, A. (Org). Ecologia de pescadores da mata Atlântica e da Amazônia. São

Paulo: Hucitec. (no prelo).

BEGOSSI, A.; GARAVELLO, J.C. Notes on the ethnoicthyology of fishermen from the Tocantins river (Brazil). Acta Amazônica, v.20, p.341-351, 1990. 
BEGOSSI, A.; FIGUEIREDO, J. L. Ethnoicthyology of southern coastal fishermen: cases from Búzios island and Sepetiba bay (Brazil). Bulletin of Marine Science, v.56, n.2, p.710-717, 1995.

BEGOSSI, A.; HANAZAKI, N.; SILVANO, R. A. M. Ecologia humana, etnoecologia e conservação. In: AMOROZO, M.C. de M.; MING, L. C.; SILVA, S.P. (Ed.). Método de coleta e análise de dados em etnobiologia, etnoecologia e disciplinas correlatas. Rio Claro/SP: UNESP/CNPq, 2002. cap.4. p.93-128.

BENDAZOLI, A.; FROSCH, L. A Pesca da Manjuba. In: BENDAZOLI, A.; ROSSIWONGTSCHOWSKI, C.L.D.B. (Coord.). A Manjuba (Anchoviella lipidentostole) no Rio Ribeira de Iguape: Biologia, Comportamento e Avaliação do estoque. São Paulo, IBAMA,IOUSP,IP-SA,SEMA. 1990. 5-7p.

BENDAZOLI, A.; ROSSI-WONGTSCHOWSKI, C.L.D.B. (Coord.). A manjuba (Anchoviella lipidentostole) no Rio Ribeira de Iguape: Biologia, comportamento e avaliação do estoque. São Paulo: IBAMA;IOUSP;IP-AS;SEMA. 1990. 125p.

BERKES, F. Competition beteen commercial and sport fishermen: an ecological analysis. Human Ecology, v.12, n.4, p.413-429, 1984.

BERKES, F. Fishermen and 'The tragedy of the commons'. Environmental Conservation, v.12, n.3, p.199-206, 1985.

BERLIN, B. Ethnobiological classification: Principles of categorization of plants e animals in societies. Princeton: Princeton University, 1992. 308p.

BERTOZZI, C.P. Análise da pesca artesanal na região de Praia Grande (SP), no período de 1999-2001. São Paulo, 2002. 226p. Dissertação (Mestrado) - Instituto Oceanográfico, Universidade de São Paulo.

CARDOSO, T.A.; BECCATO, M.A.B.; NORDI, N. Estudos etnoecológicos em comunidades de pescadores de manjuba no Parque Estadual da Ilha do Cardoso SP. In: SIMPÓSIO BRASILEIRO DE ETNOBIOLOGIA E ETNOECOLOGIA, 4., Recife, 2002. Resumos: Recife: SBEE. 2002. p.109.

CASTRO, F.; BEGOSSI, A. Fishing at Rio Grande (Brazil): Ecological niche and competition. Human Ecology, v.24, n.3, p.401-411, 1996. 
CIPÓLLI, M.N. Regime Alimentar. In: BENDAZOLI, A.; ROSSIWONGTSCHOWSKI, C.L.D.B. (Coord.). A manjuba (Anchoviella lipidentostole) no Rio Ribeira de Iguape: Biologia, comportamento e avaliação do estoque. São Paulo, IBAMA;IOUSP;IP-AS;SEMA, 1990. 17-18p.

CLAUZET, M. Ecologia da pesca artesanal de uma comunidade caiçara de Ubatuba (SP). Sorocaba: PUC/SP, 2000. (Relatório Final de Iniciação Científica - Fapesp).

CLAUZET, M. Conhecimento local e atividade pesqueira na enseada do Mar Virado, Ubatuba litoral norte, SP. São Paulo, 2003. 123p. Dissertação (Mestrado). Programa de Pós graduação em Ciência Ambiental, Universidade de São Paulo.

COSTA, S.M. As Redes da pesca: Estratégias econômicas e formas de solidariedade entre pescadores artesanais. Viçosa, 1999. 158p. Tese (Doutorado) - Universidade Federal de Viçosa.

COSTA-NETO, E. M.; MARQUES, J.G.W. Etnoictiologia dos pescadores artesanais de Siribinha, Município de Conde (Bahia): Aspectos relacionados com a etologia dos peixes. Acta Scientiarum, v.22, n.2, p.553-560, 2000a.

COSTA-NETO, E.M.; MARQUES, J.G.W. Conhecimento ictiológico tradicional e a distribuição temporal e espacial de recursos pesqueiros pelos pescadores de Conde, Estado da Bahia, Brasil. Etnoecológica, v.4, n.6, p.56-68, 2000 b.

COSTA-NETO, E.M.; MARQUES, J.G.W. A Etnotaxonomia de recursos ictiofaunísticos pelos pescadores da comunidade de Siribinha, Norte do Estado da Bahia, Brasil. Biociências, v.8,n.2, p.61-76, 2000c.

CRUZ NETO, O. O trabalho de campo como descoberta e criação. In: MINAYO, M.C.de S.; DESLANDES,S.F.;CRUZ NETO, O.; GOMES, R. (Org.) Pesquisa social: Teoria, método e criatividade. Petrópolis, RJ: Vozes, 1994. cap.3, p.51-66.

DIAS NETO, J.; DORNELLES, L.D.C. Diagnóstico da pesca marítima do Brasil. Ministério do Meio Ambiente, dos Recursos Hídricos e da Amazônia Legal. Instituto Brasileiro do Meio Ambiente e dos Recursos Naturais Renováveis. Diretoria de Incentivo à Pesquisa e Divulgação. Brasília: IBAMA. 1996. 22-155p.

DIEGUES, A.C. Pescadores, camponeses e trabalhadores do mar. São Paulo: Ática, 1983. 287p. 
DIEGUES, A.C. A pesca artesanal no litoral brasileiro: cenários e estratégias para sua sobrevivência. São Paulo: IO/USP/FFord/IUCN, 1988a. 44p.

DIEGUES, A.C. Diversidade biológica e culturas tradicionais litorâneas: O caso das comunidades caiçaras. São Paulo: NUPAUB-USP, 1988b. 22p.

DIEGUES, A. C. O Movimento social dos pescadores artesanais brasileiros. São Paulo: CEMAR: Centro de culturas marítimas, 1993. 37p. (Série documentos e relatórios de pesquisa, 8).

DIEGUES, A.C. Povos e mares: leituras em sócio-antropologia marítima. São Paulo: NUPAUB/USP, 1995. 269p.

DIEGUES, A. C. O mito moderno da natureza intocada. São Paulo: HUCITEC, 1998. 169p.

DIEGUES, A.C. (Org.). Povos e Águas: Inventário de áreas úmidas brasileiras. São Paulo: Núcleo de Apoio a Pesquisa sobre Populações Humanas e Áreas Úmidas Brasileiras, USP, 2002. 597p.

DIEGUES, A.C.; NOGARA, P. O nosso lugar virou parque: um estudo sócioambiental do Saco Mamangá - Paraty/RJ. 2.ed. São Paulo: NUPAUB,USP, 1999. 187p.

DIEGUES, A.C.; ARRUDA, R.S.V. (Org.). Saberes tradicionais e biodiversidade no Brasil. Brasília: Ministério do Meio Ambiente. São Paulo: USP, 2001. 176p. (Biodiversidade, 4).

EMBRATUR - Instituto Brasileiro de Turismo. Pólo do Ecoturismo: Planejamento e Gestão/ Guilherme Wendel de Magalhães (coordenador). São Paulo: TERRAGRAF. 2001. 1v.

FERNANDES-PINTO, E. “Cada peixe tem sua mistura”: Percepção dos pescadores de Guaraqueçaba/PR sobre ecologia trófica das espécies ícticas. In: SIMPÓSIO BRASILEIRO DE ETNOBIOLOGIA E ETNOECOLOGIA, 4., Recife, 2002. Livro de Resumos. Recife: SBEE. 2002. p128.

FIGUEIREDO, J.L.; MENEZES, N. A. Manual de peixes marinhos do sudeste do Brasil: II. Teleostei (1). São Paulo: Museu de Zoologia da Universidade de São Paulo. 1978. 110p. 
FIGUEIREDO, J.L.; MENEZES, N.A. Manual de peixes marinhos do sudeste do Brasil: III. Teleostei (2). São Paulo: Museu de Zoologia da Universidade de São Paulo. 1980. 90p.

FIGUEIREDO, J.L.; MENEZES, N.A. Manual de peixes marinhos do sudeste do Brasil: VI. Teleostei (5). São Paulo: Museu de Zoologia da Universidade de São Paulo. 2000. 116p.

HANAZAKI, N. Conhecimento e uso de plantas, pesca e dieta em comunidades caiçaras do município de Ubatuba (SP). São Paulo, 1997. 136p. Dissertação (Mestrado) Instituto de Biociências - Universidade de São Paulo.

HANAZAKI, N., LEITÃO-FILHO, H., BEGOSSI, A. Uso de recursos na mata Atlântica: O caso da ponta do Almada (Ubatuba, Brasil). Interciencia, v.21, n.6, p.268-276. nov-dec. 1996.

HANAZAKI, N. Ecologia de caiçaras: Uso de recursos e dieta. Campinas, 2001. 193p. Tese (Doutorado) - Instituto de Biologia. Universidade Estadual de Campinas.

HANAZAKI, N. Conhecimento caiçara para o manejo de recursos naturais. In: ALBUQUERQUE, U.P. (Org.). Atualidades em etnobiologia e etnoecologia. Recife: Sociedade Brasileira de Etnobiologia e Etnoecologia, 2002. cap.2. p. 17-25. HOFLING, E.; OLIVEIRA, A.M.S.; RODRIGUES, M.T.; TRAJANO, E.; ROCHA, P.L.B. Chordata: Manual para um curso prático. São Paulo: Ed. Universidade de São Paulo, 1995. 242p.

KORMONDY, E. J.; BROWN, D. E. Ecologia humana. Trad Max Blum. São Paulo: Atheneu, 2002. 503p.

LEFF, E. Ecologia, capital e cultura: racionalidade ambiental, democracia participativa e desenvolvimento sustentável. Trad. J. Esteves da Silva. Blumenau: EDIFURB, 2000. 373p.

LEFF, E. Saber ambiental: sustentabilidade, racionalidade, complexidade e poder. Trad. L.M.E. Orth. Petrópolis: Vozes, 2001b. 343p.

LOPES, P.F.M. Ecologia caiçara: Pesca e uso de recursos na comunidade da praia do Puruba. Campinas, 2004. 117p. Dissertação (Mestrado) - Instituto de Biologia, Universidade Estadual de Campinas. 
LOWE-MCCONNEL, R.H. Estudos ecológicos de comunidades de peixes tropicais. Trad. de A.E.A.M. Vazzoler; A.A. Agostinho; P.T.M. Cunnhinghan. São Paulo: Editora da Universidade de São Paulo, 1999. 534p.

LUCHIARI, M.T.D.P. Caiçaras, migrantes e turistas: A tragetória da apropriação da natureza no litoral norte Paulista (São Sebastião - Distrito de Maresias). Campinas, 1992. 210p. Dissertação (Mestrado) - Departamento de Sociologia, Universidade Estadual de Campinas.

LUCHIARI, M.T.D.P. Turismo e cultura caiçara no litoral norte Paulista. In: RODRIGUES, A.B. (Org). Turismo, modernidade e globalização. São Paulo: Hucitec, 1997. 136p.

LUDKE, M.; ANDRÉ, M.E.D.A. Pesquisa em educação: Abordagens qualitativas. São Paulo: EPU, 1986. 99p.

MALDONADO, S.C. Pescadores do mar. São Paulo: Ática, 1986. 77p. (Série Princípios).

MALDONADO, W. Comunidades caiçaras e o Parque Estadual de Ilhabela. In: DIEGUES, A.C.S. (Org). Ilhas e sociedades insulares. São Paulo: NUPAUB-USP. 1997. cap 6. p.123-136.

MARQUES, J.G.W. Aspectos ecológicos na ecologia dos pescadores do complexo estuarino - Lagunar de Mandaú - Manguaba, Alagoas. Campinas, 1991. 296p. Tese (Doutorado) - Instituto de Biologia, Universidade Estadual de Campinas.

MARQUES, J.G. Pescando pescadores: ciência e etnociência em uma perspectiva ecológica. 2.ed. São Paulo: NUPAUB, USP, 2001. 258p.

MARQUES, J.G. O olhar (des)multiplicado: o papel do interdisciplinar e do qualitativo na pesquisa etnobiológica e etnoecológica. In: AMOROZO, M.C. de M.; MING, L.G.; SILVA, S.P. (Ed.) Métodos de coleta e análise de dados em etnobiologia, etnoecologia e disciplinas correlatas. Rio Claro/SP: UNESP, CNPq, 2002. 204p. cap.2, p.31-45.

MENDONÇA, J.T.; KATSURAGAWA, M. Caracterização da pesca artesanal no complexo estuarino lagunar de cananéia - Iguape, Estado de São Paulo, Brasil (1995-1996). Acta Scientiarum, v.23, n.2, p.535-547, 2001. 
MENEZES, N. A.; FIGUEIREDO, J. L. Manual de peixes marinhos do sudeste do Brasil: IV. Teleostei (3). São Paulo: Museu de Zoologia da Universidade de São Paulo, 1980. 96p.

MENEZES, N.A.; FIGUEIREDO, J.L. Manual de peixes marinhos do sudeste do Brasil: V. Teleostei (4). São Paulo: Museu de Zoologia da Universidade de São Paulo, 1985. 105p.

MERGULHÃO, M.C.; VASAKI, B.N.G. Educando para a conservação da natureza: Sugestões de atividades em educação ambiental. São Paulo: EDUC, 1998.139p.

MORAN, E.F. A ecologia humana das populações da Amazônia. Petrópolis: Vozes, 1990. 367p. (Coleção Ecologia \& ecosofia).

MOURÃO. J. da S. Classificação e ecologia de peixes estuarinos por pescadores do estuário do Rio Mamanguape, PB. São Carlos, 2000. 131p. Tese (Doutorado) Centro de Ciências Biológicas e da Saúde, Universidade Federal de São Carlos.

MOURÃO, J.S.; NORDI, N. Principais critérios utilizados por pescadores artesanais na taxonomia Folk dos peixes do estuário do Rio Mamanguape, Paraíba-Brasil. Interciencia, v.27, n.11, p.607-612, 2002a.

MOURÃO, J.S.; NORDI, N. Comparações entre as taxonomias Folk e científica para os peixes do estuário do Rio Mamanguape, Paraíba-Brasil. Interciencia, v.27,n.12, p.664-668, 2002b.

NAZAREA, V.D. Introduction: A view from a point: Ethnoecology as situated knowledge. IN: NAZAREA, V.D. Ethnoecology: Situated knowledge/located lives. The University of Arizona Press. 1999.

NOGARA, P.J.N. Proteção e gestão participativa dos recursos pesqueiros do Saco do Mamanguá, Paraty/ Rio de Janeiro. In: DIEGUES, A.C.S.; VIANA, V.M. (Org.). Comunidades tradicionais e manejo dos recursos naturais da mata Atlântica. São Paulo: NUPAUB, USP, 2000. p.131-142.

PAZ, V. A.; BEGOSSI, A. Ethnoichthyology of Gamboa: Fishermen of Sepetiba bay, Brazil. Journal of Ethnobiology, v.16, n.2, p.157-168, 1996. 
PIRES, P.S. Ecoturismo: Uma abordagem histórica e conceitual na perspectiva ambientalista. São Paulo, 1998. 218p. Tese (Doutorado) - Faculdade de Filosofia, Letras e Ciências Humanas, Universidade de São Paulo.

PLANTE, S.; BRETON, Y. Espaço, pesca e turismo em Trindade. São Paulo: NUPAUB, USP, 1997. 76p. (Série documentos e relatório de pesquisa, 23).

POSEY, D. A. Etnobiologia: Teoria e prática. In: RIBEIRO, B. G. SUMA Etnológica Brasileira. Petrópolis: Vozes, 1986. v.1 (etnobiologia). cap.1. p.15-25.

POSEY. D. A. Os povos tradicionais e a conservação da biodiversidade. s.l., Secretaria do meio ambiente. SEMAM, 1992. 403-409p.

PRADO, R.A. Pesca esportiva. Fishing news, v.6, n.67, p.8, 1999.

RAMIRES, M.; BARRELLA, W. A pesca na Estação Ecológica de Juréia Itatins: Ecologia e etnoictiologia em comunidades caiçaras. Sorocaba: PUC/SP, 2001a. 82p. (Relatório Final de Iniciação Cientifica - FAPESP).

RAMIRES, M.; BARRELLA, W. A Pesca esportiva como alternativa econômica em uma população caiçara da Estação Ecológica de Juréia Itatins. PUC-SP Ciências Biológicas e do Ambiente, v.3, n.1, p.39-51, 2001 b.

RAMIRES, M.; BARRELlA, W.; CLAUZET, M. A Pesca artesanal no Vale do Ribeira e litoral sul do Estado de São Paulo. Encontro Nacional de Pós Graduação e Pesquisa em Ambiente e Sociedade (ANPPAS). Trabalho completo apresentado no I Grupo de trabalhos 3: Biodiversidade e Recursos Naturais. Indaiatuba/SP: 6 a 9 de novembro de 2002. http://www.anppas.org.br/encontro_trabalhos.html . 2002. (14 de janeiro de 2003).

RAMIRES, M.; BARRELA, W. Ecologia da pesca artesanal em população caiçara de Juréia - Itatins, São Paulo, Brasil. Interciencia, n.4, p.208-213, 2003.

RAMIRES, M.; BARRELLA, W. Etnoictiologia dos pescadores artesanais da Estação Ecológica de Juréia Itatins (São Paulo-Brasil). In: DIEGUES, A.C. (Org.). Enciclopédia Caiçara. São Paulo: Núcleo de apoio a pesquisa sobre populações humanas em áreas úmidas brasileiras (NUPAUB), no prelo.

RIBARIC, R.A. Caiçaras: Para uma arqueologia da memória. São Paulo, 1996. Dissertação (Mestrado) - Pontifícia Universidade Católica de São Paulo. 
RIBARIC, A. Sítio Artur e os seus: Para uma arqueologia da memória. In: DIEGUES, A. C. S. (Org). Ilhas e sociedades insulares. São Paulo: NUPAUB,USP, 1997. cap.5, p.203-220.

SACHS, I. Ecodesenvolvimento: crescer sem destruir. Trad. E. Araújo. São Paulo: Vértice, 1986. 207p. (Terra dos homens).

SACHS, I. Do crescimento econômico ao ecodesenvolvimento. In: VIEIRA, P.F.; RIBEIRO, M.A.; FRANCO, R.M. et al (Org.) Desenvolvimento e meio ambiente no Brasil: a contribuição de Ignacy Sachs. Porto Alegre: Pallotti, 1998. cap.6, p.161-164.

SANCHES, R. A. Estudos etnozoológicos nas comunidades tradicionais da Estação Ecológica de Juréia Itatins. In: CONGRESSO INTERNACIONAL DE ETNOBIOLOGIA, 3., Cidade do México, 1992. Anais México: s.ed. 1992.

SANCHES, R. A. Caiçaras e a Estação Ecológica de Juréia- Itatins (Litoral Sul de São Paulo: Uma abordagem etnográfica e ecológica para o estudo da relação homem-meio ambiente. São Paulo, 1997. 209p. Dissertação (Mestrado) - Instituto de Biociências, Universidade de São Paulo.

SANCHES, R. A. Caiçaras e a Estação Ecológica de Juréia Itatins: Histórico de ocupação no contexto político, econômico, social e ambiental do Vale do Ribeira. In: MARQUES, O.A.; DULEBA, W. (Ed.). Estação Ecológica Juréia Itatins: Ambiente físico, flora e fauna. Ribeirão Preto: Holos, 2004. cap.28. p.349-359.

SÃO PAULO (Estado). Secretaria de Estado do Meio Ambiente. Macrozoneamento do complexo estuarino lagunar de Iguape e Cananéia. São Paulo, 1990. 158p.

SÃO PAULO (Estado). Secretaria de Estado do Meio Ambiente. Coordenadoria de Educação Ambiental. Educação ambiental em unidades de conservação e de produção. São Paulo, 1991. (série guias).

SÃO PAULO (Estado). Secretaria de Estado do Meio Ambiente. Secretaria da Educação. Programa de Educação Ambiental do Vale do Ribeira. São Paulo, 1992. 344p. (Série Educação Ambiental). 
SÃO PAULO (Estado). Secretaria de Estado do Meio Ambiente. Diagnostico ambiental participativo do Vale do Ribeira e Litoral Sul de São Paulo. São Paulo: IBAMA,SMA,UNICAMP, 1998a.86p.

SÃO PAULO (Estado). Secretaria de Estado do Meio Ambiente. Em busca da sustentabilidade do Vale do Ribeira e Litoral Sul de São Paulo. São Paulo: IBAMA, SMA, UNICAMP, 1998b. 35p.

SEIXAS, C. S.; BEGOSSI, A. Central place optimal foraging theory: Population and individual analyses of fishing strategies at Aventureiro (Ilha Grande, Brazil). Ciência e Cultura, v.52, n.2, p.85-91, 2000.

SERRALHEIRO, P.C.S.; GODINHO,H.M.; OLIVEIRA, I.R.; BASTOS, A.A. O cultivo de peixes estuarinos no complexo estuarino lagunar Iguape-Ilha Comprida- Cananéia: Uma contrição para a utilização dos recursos pesqueiros autóctones. In: DIEGUES, A.C.; VIANA, V.M. (Org.). Comunidades tradicionais e manejo de recursos naturais da mata Atlântica. São Paulo: NUPAUB,USP, 2000. cap.16. p.167-176.

SILVA, L.G.S. da. Caiçaras e jangadeiros: Cultura marítima e modernização no Brasil. São Paulo: CEMAR - Centro de Culturas Marítimas/USP, 1993.143p.

SILVA, T.E.; TAKAHASHI, L.T.; VERAS, F.A.V. As Várzeas Ameaçadas: Um estudo preliminar das relações entre as comunidades humanas e o recursos naturais da Várzea da Marituba no Rio São Francisco. São Paulo: Programa de Pesquisas e Conservação de Áreas Úmidas no Brasil, 1990. 144p.

SILVANO, R. A. M. Ecologia de três comunidades de pescadores do Rio Piracicaba (SP). Campinas, 1997. 147p. Dissertação (Mestrado) - Instituto de Biologia, Universidade Estadual de Campinas.

SILVANO, R.A.M.; BEGOSSI, A. Ethnoichthyology and fish conservation in the Piracicaba river (Brazil). Journal of Ehnobiology, v.22, n.2, p.285-306, 2002.

SOARES, D. (Org.). Pesca Amadora. São Paulo, Nobel. 2001.

SOUZA, M. R.; BARRELLA, W. Conhecimento popular sobre peixes numa comunidade caiçara da Estação Ecológica de Juréia - Itatins/SP. Boletim do Instituto de Pesca, n.27, p.123-130, 2001. 
THÉ, A.P.G. Estudo sobre o regime de propriedade comum em duas comunidades de pescadores do Rio São Francisco, MG. In: SIMPÓSIO BRASILEIRO DE ETNOBiOlogia E ETNOeCOlOGiA, 4., Recife, 2002. Livro de Resumos. Recife: s.ed., 2002. p.29.

VAZZOLER, A.E.A.M. Biologia da reprodução de peixes teleósteos: Teoria e prática. Maringá: EDUEM, SBI, 1996. 169p.

VIERTLER, R.B. Método antropológico como ferramenta para estudos em etnobiologia e etnoecologia. In: AMOROZO, M.C. de M.; MING, L.C.; SILVA, S.P. (Ed.). Método de coleta e análise de dados em etnobiologia, etnoecologia e disciplinas correlatas. Rio Claro: Coordenadoria de Área de Ciências Biológicas - UNESP, CNPq, 2002. cap.1, p.11-29. 
Anexos 
Anexo A: Pescador Artesanal

Local

\begin{tabular}{|l|l|}
\multicolumn{2}{|l}{ Data: / / } \\
\hline Nome do Rio / Praia & Tipo \\
\hline & $\begin{array}{ll}\text { ( ) 1. Colônia/ pesca } & \text { ( ) 5. Estuário } \\
\text { ( ) 2. Domicílio } & \text { ( ) 6. Praia } \\
\text { ( ) 3. Acampamento } & \text { ( ) 7. Outro: } \\
& \text { ( ) 4. Beira do rio }\end{array}$ \\
\hline
\end{tabular}

Dados Gerais do Informante

\begin{tabular}{|l|l|l|l|l|l|l|l|}
\hline $\begin{array}{l}\text { Idade } \\
\text { anos }\end{array}$ & Sexo & Instrução & $\begin{array}{l}\text { Possui } \\
\text { outra } \\
\text { Profissão }\end{array}$ & $\begin{array}{l}\text { Renda } \\
\text { Mensal }\end{array}$ & $\begin{array}{l}\text { Importância } \\
\text { da pesca no } \\
\text { orçamento }\end{array}$ & $\begin{array}{l}\text { Há quanto } \\
\text { tempo } \\
\text { pesca? }\end{array}$ & $\begin{array}{l}\text { Possui } \\
\text { alguma } \\
\text { propriedade? }\end{array}$ \\
\hline & & & & $\begin{array}{l}\text { ( ) total } \\
\text { ( ) parcial } \\
\text { ( ) pequena }\end{array}$ & & \\
\hline
\end{tabular}

\section{Roteiros}

\begin{tabular}{|c|c|c|c|c|}
\hline $\begin{array}{l}\text { Freqüência de } \\
\text { pescarias }\end{array}$ & \begin{tabular}{|l}
$\begin{array}{l}\text { Melhores locais de } \\
\text { pesca }\end{array}$ \\
\end{tabular} & $\begin{array}{ll}\begin{array}{l}\text { Distância da } \\
\text { casa }\end{array} & \text { da } \\
\end{array}$ & $\begin{array}{l}\text { Tempo médio de } \\
\text { pescarias }\end{array}$ & $\begin{array}{l}\text { Aparelhos/ } \\
\text { métodos utilizados }\end{array}$ \\
\hline \multirow{3}{*}{$\begin{array}{l}\text { ( } \quad \text { ) diária } \\
\text { ( } \quad \text { ) semanal } \\
\text { ( ) quinzenal } \\
\text { ( } \quad \text { ) mensal }\end{array}$} & 1) & & & \\
\hline & 2) & & & \\
\hline & (3) & & & \\
\hline
\end{tabular}

Equipamentos e Técnicas

\begin{tabular}{|l|l|l|l|l|l|}
\hline $\begin{array}{l}\text { Equipamento que possui } \\
\text { Quantidade e tipos }\end{array}$ & $\begin{array}{l}\text { Quais espécies de } \\
\text { peixes mais } \\
\text { procuradas? }\end{array}$ & $\begin{array}{l}\text { Onde são } \\
\text { pescadas? }\end{array}$ & $\begin{array}{l}\text { Quando? } \\
\text { (Método } \\
\text { utilizado) }\end{array}$ & Preço? \\
\hline & 2) & & & & \\
\hline 3$)$ & & & & \\
\hline 4$)$ & & & & \\
\hline 5$)$ & $6)$ & & & & \\
\hline & $7)$ & & & & \\
\hline
\end{tabular}


Forma de Comércio

\begin{tabular}{|l|l|l|l|}
\hline mais comum & $\begin{array}{l}\text { Nome de empresas ou } \\
\text { comerciantes }\end{array}$ & $\begin{array}{l}\text { Município que se } \\
\text { localiza }\end{array}$ & Forma de comércio \\
\hline ( ) ao consumidor & & & \\
( ) cooperativa & & & \\
( ) colônia & & & \\
( ) mercado & & \\
( ) frigorífico & & & \\
( ) industria & & & \\
( ) outro & & & \\
\hline
\end{tabular}

Na sua opinião, para a pesca quais são melhores... ?

\begin{tabular}{|l|l|l|l|l|}
\hline meses do ano & $\begin{array}{l}\text { Época } \\
\text { (chuva/seca) }\end{array}$ & Horas do dia & Fases da lua & Nível da maré \\
\hline & & & & \\
& & & & \\
\hline
\end{tabular}

Qualidade do Pesqueiros da Região

\begin{tabular}{|c|c|c|c|}
\hline Qualidade do pesqueiro & $\begin{array}{l}\text { Relação com anos } \\
\text { anteriores }\end{array}$ & \begin{tabular}{|l|} 
Tamanho dos \\
Peixes capturados
\end{tabular} & Porque? \\
\hline $\begin{array}{l}\text { ( ) Bom } \\
\text { ( ) Regular } \\
\text { ( ) Ruim }\end{array}$ & $\begin{array}{l}\text { ( ) melhorou } \\
\text { ( ) a mesma } \\
\text { ( ) piorou }\end{array}$ & 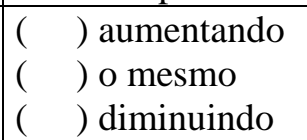 & \\
\hline
\end{tabular}

Obs: 
Anexo B

Etnoictiologia

Local/ Comunidade:

Data:

Município:

Nome do entrevistado:

1. Identificação do Peixe:

Nome popular:

2. Descrição do Peixe:

Diferenças entre jovens e adultos:

Diferenças entre machos e fêmeas:

\section{Habitat:}

Ambiente em que vive:

4. Distribuição vertical:

( ) fundo ( ) meia água ( ) superfície ( ) outro

5. Alimentação:

O que este peixe come?

6. Comportamento:

Hábito: ( ) solitário ( ) cardume ( ) outro

Que peixes se alimentam desta espécie?

7. Época de reprodução:

8. Que técnica de pesca é mais freqüentemente utilizada para capturar este peixe?

9. Quantos tipos (espécies) deste peixe existem na região? Quais você conhece? 
Anexo C

Pescador esportivo

Local

Data: / /

\begin{tabular}{|c|c|c|c|}
\hline Município & Nome do local & Nome do Rio / Praia & Tipo \\
\hline & & & $\begin{array}{l}\text { ( ) } 1 \text {. Clube de pesca ( ) } 5 \text {. Estuário } \\
\text { ( ) } 2 \text {. Hotel ( ) 6. Praia } \\
\text { ( ) } 3 \text {. Acampamento ( ) } 7 \text {. Outro: } \\
\text { ( ) } 4 \text {. Beira do rio }\end{array}$ \\
\hline
\end{tabular}

Dados Gerais do Informante

\begin{tabular}{|c|l|l|l|l|l|l|}
\hline $\begin{array}{c}\text { Idade } \\
\text { anos }\end{array}$ & Sexo & Instrução & Profissão & $\begin{array}{c}\text { Renda } \\
\text { Mensal }\end{array}$ & Documentos que possui & $\begin{array}{c}\text { Possui propriedade } \\
\text { aqui? Onde? }\end{array}$ \\
\hline & & & & & ( ) 1. Nenhum & ( ) 2. Pescador Desportivo \\
& & & & $\begin{array}{l}\text { ( ) 3. Pescador Profissional } \\
\text { () 4. Piloto de barco } \\
\text { () 5. Outro: }\end{array}$ & \\
\hline
\end{tabular}

Residência e Roteiro:

\begin{tabular}{|c|c|c|c|c|c|c|}
\hline $\begin{array}{l}\text { Cidade/ } \\
\text { Estado }\end{array}$ & $\begin{array}{c}\text { Distância } \\
\text { do local }\end{array}$ & Freqüência & $\begin{array}{c}\text { Tempo de } \\
\text { pesca }\end{array}$ & $\begin{array}{l}\text { Número de } \\
\text { pescadores }\end{array}$ & $\begin{array}{l}\text { Onde estão } \\
\text { hospedados }\end{array}$ & $\begin{array}{l}\text { Contrata/compra/ } \\
\text { aluga na região }\end{array}$ \\
\hline & & $\begin{array}{l}\text { ( ) semanal } \\
\text { ( ) quinzenal } \\
\text { ( ) férias } \\
\text { ( ) primeira } \\
\text { vez }\end{array}$ & & & & $\begin{array}{ll}\text { ( ) piloto/guia } \\
\text { ( ) barco } \\
\text { ( ) cozinheiro } \\
\text { ( ) iscas vivas } \\
\text { ( ) mantimentos } \\
\text { ( ) caseiro } \\
(\text { ) outro: }\end{array}$ \\
\hline
\end{tabular}

Equipamentos e Técnicas

\begin{tabular}{|c|c|c|c|c|}
\hline Quantidade e tipos & $\begin{array}{l}\text { Quais espécies de peixes } \\
\text { mais procuradas? }\end{array}$ & $\begin{array}{l}\text { Onde são } \\
\text { pescadas? }\end{array}$ & Quando? & Como? \\
\hline \multirow{6}{*}{$\begin{array}{l}\text { ( ) Veículos } \\
\text { ( ) Reboques } \\
\text { ( ) Barcos } \\
\text { ( ) Motor }{ }_{\text {( }} \text { ) Varas e caniços } \\
\text { ( ) Molinetes/carretilhas } \\
\text { ( ) Geladeiras_litros } \\
\text { ( ) Geradores elétricos } \\
\text { ( ) Barracas } \\
\text { ( ) Iscas vivas_ } \\
\text { ( ) Iscas artificiais } \\
\text { ( ) Outras }\end{array}$} & & & & \\
\hline & & & & \\
\hline & & & & \\
\hline & & & & \\
\hline & & & & \\
\hline & & & & \\
\hline
\end{tabular}

\section{Qualidade do Pesqueiro}

\begin{tabular}{|l|l|l|l|l|}
\hline Qualidade do pesqueiro & $\begin{array}{l}\text { Relação com anos } \\
\text { anteriores }\end{array}$ & $\begin{array}{l}\text { Conhece outro bom } \\
\text { ponto de pesca na } \\
\text { região? Onde? }\end{array}$ & $\begin{array}{l}\text { Conhece um } \\
\text { bom pescador } \\
\text { local? }\end{array}$ & $\begin{array}{l}\text { Indique um } \\
\text { ponto turístico } \\
\text { regional }\end{array}$ \\
\hline $\begin{array}{l}\text { ( } \quad \text { ) Bom } \\
\text { ( ) Regular } \\
\text { ( }) \text { Ruim }\end{array}$ & $\begin{array}{l}\text { ( ) melhorou } \\
\text { ( ) a mesma } \\
\text { ( ) piorou }\end{array}$ & & & \\
\hline
\end{tabular}

Gostaria de fazer algum comentário sobre a pesca e ou turismo da região? 


\section{Anexo D}

Listagem das Etnoespécies citadas pelos pescadores artesanais de todos os municípios visitados.

\begin{tabular}{|c|c|}
\hline Etnoespécies & Espécies Identificadas \\
\hline \multicolumn{2}{|l|}{ Bagre } \\
\hline \multicolumn{2}{|l|}{ Bagre-africano } \\
\hline Bagre-branco & Netuma barba \\
\hline \multicolumn{2}{|l|}{ Bagre-marinho } \\
\hline Bagre-urutu & Genidens genidens \\
\hline Betara & Menticirrhus sp. \\
\hline Cação anjo & Squatina argentina \\
\hline \multicolumn{2}{|l|}{ Cação azul } \\
\hline \multicolumn{2}{|l|}{ Cação branco } \\
\hline \multicolumn{2}{|l|}{ Cação chapéu } \\
\hline \multicolumn{2}{|l|}{ Cação galha preta } \\
\hline \multicolumn{2}{|l|}{ Cação martelo } \\
\hline \multicolumn{2}{|l|}{ Cação pão } \\
\hline Cação viola & Rhinobatos sp. \\
\hline \multicolumn{2}{|l|}{ Cação tintureiro } \\
\hline Cangangá & Stellifer brasiliensis \\
\hline Cara & Geophagus brasiliensis \\
\hline Caranha & Lutjanus sp. \\
\hline Carapeva & Diapterus rhombeus \\
\hline Carapau & Caranx bartholomaei \\
\hline Caratinga & Eugerres brasilianus \\
\hline Cascudo & Hypostomus commersonii \\
\hline \multicolumn{2}{|l|}{ Cascudo aniam } \\
\hline \multicolumn{2}{|l|}{ Cascudo barbudo } \\
\hline \multicolumn{2}{|l|}{ Cascudo guacari } \\
\hline \multicolumn{2}{|l|}{ Cascudo preto } \\
\hline \multicolumn{2}{|l|}{ Cascudo pijiara } \\
\hline \multicolumn{2}{|l|}{ Cascudo pito } \\
\hline \multirow{2}{*}{\multicolumn{2}{|c|}{$\begin{array}{l}\text { Cascudo rabo seco } \\
\text { Cavala }\end{array}$}} \\
\hline & \\
\hline \multicolumn{2}{|l|}{ Cavalinha } \\
\hline Corvina & Micropogonias furnieri \\
\hline Curimatá & Prochilodus lineatus \\
\hline Emborê & Gobionellus sp. \\
\hline Escrivão & Eucinostomus sp. \\
\hline Garoupa & Mycteroperca sp. \\
\hline \multicolumn{2}{|l|}{ Gravivê } \\
\hline \multicolumn{2}{|l|}{$\begin{array}{l}\text { Gravivê branco } \\
\text { Gravivê vermelho }\end{array}$} \\
\hline \multicolumn{2}{|l|}{ Gravivê vermelho } \\
\hline \multicolumn{2}{|l|}{ Jacundá } \\
\hline Lambari & Deuterodon iguape \\
\hline \multicolumn{2}{|l|}{ Lambari branco } \\
\hline \multicolumn{2}{|l|}{ Lambari guaçú } \\
\hline Lambari listrado & Hollandichthys multifasciatus \\
\hline Lambari pequeno & \\
\hline Lambari rabo vermelho & \\
\hline Lambari vermelho & \\
\hline Linguado & Citharichthys arenaceus \\
\hline
\end{tabular}


Listagem das Etnoespécies citadas pelos pescadores artesanais de todos os municípios visitados. Continuação.

\begin{tabular}{|c|c|}
\hline \multicolumn{2}{|l|}{ Lisbão } \\
\hline Mandi & Pimelodella sp. \\
\hline \multicolumn{2}{|l|}{ Mandizinho } \\
\hline Mandi-pintado & Pimelodus maculatus \\
\hline Manjuba & Anchoviella lepidentostole \\
\hline \multicolumn{2}{|l|}{ Manjubão } \\
\hline \multicolumn{2}{|l|}{ Manjuba prego } \\
\hline Manjuba-savelha & Cetengraulis edentulus \\
\hline \multicolumn{2}{|l|}{ Mero } \\
\hline Mussum & Symbranchus marmuratus \\
\hline \multicolumn{2}{|r|}{ 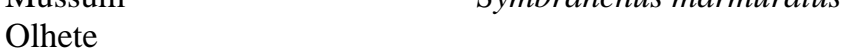 } \\
\hline Oveva & Larimus breviceps \\
\hline Pacu & Piaractus mesopotamicus \\
\hline Papa-terra & Menticirrhus americanus \\
\hline Parati & Mugil sp. \\
\hline Parati barbado & Mugil sp. \\
\hline Parati chorão & Mugil sp. \\
\hline Parati do rio & Mugil sp. \\
\hline Parati flecha & Mugil sp. \\
\hline Parati guaçú & Mugil sp. \\
\hline Parati pema & Mugil sp. \\
\hline Parati Poá & Mugil sp. \\
\hline Parati sabão & Mugil sp. \\
\hline Paru & Chaetodipterus faber \\
\hline Peixe agulhão & Tylosurus avus \\
\hline Peixe-cachimbo & Oostethus linearus \\
\hline \multicolumn{2}{|l|}{ Peixe-cobra } \\
\hline Peixe-sabão & Rypticus randalli \\
\hline Pescada & Cynoscion sp. \\
\hline Pescada-amarela & Cynoscion acoupa \\
\hline Pescada-branca & Cynoscion leiarchus \\
\hline \multicolumn{2}{|l|}{ Pescada-banana } \\
\hline Pescada cambucu & Cynoscion virescens \\
\hline \multicolumn{2}{|l|}{ Pescada fogueta } \\
\hline \multicolumn{2}{|l|}{ Pescada jaguará } \\
\hline \multicolumn{2}{|l|}{ Pescada olhuda } \\
\hline \multicolumn{2}{|l|}{ Pescada sacu } \\
\hline Pescadinha & Isopisthus parvipinnis \\
\hline Piaba & Leporinus coplandii \\
\hline Piau & Leporinus obtusidens \\
\hline \multicolumn{2}{|l|}{ Piraputanga } \\
\hline \multicolumn{2}{|l|}{ Pito } \\
\hline \multicolumn{2}{|l|}{ Pituva } \\
\hline \multicolumn{2}{|l|}{ Preguinho } \\
\hline \multicolumn{2}{|l|}{ Prejereba } \\
\hline Robalo & Centropomus sp. \\
\hline Robalão & Centropomus sp. \\
\hline Robalo água branca & Centropomus sp. \\
\hline Robalo cambuiapeva & Centropomus sp. \\
\hline Robalo-flecha & Centropomus undecimalis \\
\hline
\end{tabular}


Listagem das Etnoespécies citadas pelos pescadores artesanais de todos os municípios visitados. Continuação.

\begin{tabular}{ll}
\hline Robalo galhudo & Centropomus sp. \\
Robalo peba-guaçu & Centropomus sp. \\
Robalo-peba & Centropomus parallelus \\
Robalo tirrinha & Centropomus sp. \\
Roncador & Bardiella ronchos \\
Sagüiru & Cyphocharax santacatarinae \\
Saicanga & Oligosarcus hepsetus \\
Salteira & \\
Salteira branca & \\
Salteira vermelha & \\
Sardinha & Anchovia clupeiodes \\
Sardinha-branca & Anisotremus surinamensis \\
Sargo de beiço & Archosargus sp. \\
Sargo de dente & Bagre bagre \\
Sassari & Scomberomorus brasiliensis \\
Sororoca & Mugil sp. \\
Tainha & Mugil sp. \\
Tainha grande & Mugil sp. \\
Tainha tara & Mugil sp. \\
Tainhota & \\
Taputanga & \\
Tilápia & Hoplias malabaricus \\
Traíra & \\
Traíra açu & \\
Traíra amarela & \\
Traíra preta & Mugil sp. \\
Virotão & Mugil sp. \\
Virote & Mugil sp. \\
Virotinho & \\
Xaréu & \\
\hline
\end{tabular}

